\title{
DESIGN AND CONSTRUCTION FEATURES THAT CAUSE NEW HOUSES IN NEW ZEALAND TO OVERHEAT
}

By

Lisa French

A thesis submitted to Victoria University of Wellington in fulfilment of the requirements for the degree of Masters of Building Science

Victoria University of Wellington

April 2008 


\section{Abstract}

Analysis of indoor temperature measurements taken in 397 randomly selected houses has revealed that New Zealand houses are becoming warmer in summer. Houses built at the end of the $20^{\text {th }}$ century are during the daytime ( 9 am to $5 \mathrm{pm}$ ), on average, $2.5^{\circ} \mathrm{C}$ warmer during summer months (December to February) than houses built at the start. For example, in houses built during the 1990s, temperatures above $25^{\circ} \mathrm{C}$ are found $40 \%$ of the time during the summer early evening ( 4 pm to $6 \mathrm{pm}$ ) temperatures that could be considered as uncomfortably warm in a temperate climate.

Since 2006 there has been a rapid uptake of heat pumps in New Zealand, and a survey provides evidence of a growing number of households actively cooling, when traditionally very little cooling has been done. The ability for occupants to cool during the warm summer early evening has the potential to create an additional peak load on the electricity network.

The trend towards increasing indoor summer temperatures could be due to a range of features, including house design, construction and operation. These have been explored through analysis of the temperature data and thermal modelling using SUNREL with validated models of five houses. Although the monitored sample was sizable, the variation in occupant behaviour means it was not possible to explore all potential drivers or eliminate other influences. The use of thermal modelling permitted parametric investigation of the role of different features to be explored. 
The analysis of monitoring data and the thermal modelling showed that the main causes of increasing temperatures are: increasing glazing area; lower ventilation rates; reduction of external shading through reduced eave size; and to a lesser extent increased levels of thermal insulation. These findings have been used to provide guidance for new house designers as well as suggestions for modifications of existing houses. 


\section{Keywords}

Overheating, summer temperature, cooling, sustainable design

\section{Acknowledgements}

I would like to acknowledge the support and advice of my supervisors Michael Donn (Victoria University of Wellington) and Nigel Isaacs (BRANZ Ltd and Victoria University of Wellington). This work would not have been possible without the support of BRANZ Ltd and the Household Energy End-use Project (HEEP) team, in particular Nigel Isaacs and Michael Camilleri. I have also had valuable assistance and support from a number of my colleagues at BRANZ Ltd including Andrew Pollard, Eddie Bruce, Lynda Amitrano and Chris Kane. I would like to thank Krystal Stewart (BRANZ summer student and Victoria University of Wellington student) who helped with the initial set up of the thermal models. In completing this work I have appreciated the assistance of a NERI scholarship for postgraduate energy research. Lastly, I would like to thank Simon for his support. 
"For your home to be comfortable yet use as little energy as possible, working with nature rather than against it is the fundamental principle."

(Pearson 1998) 


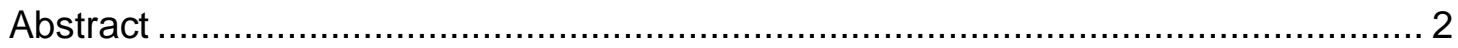

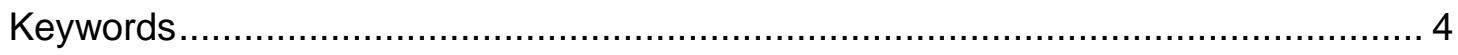

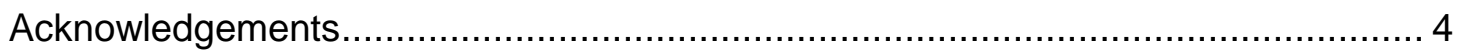

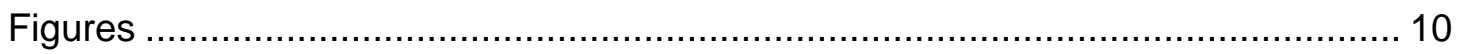

Tables

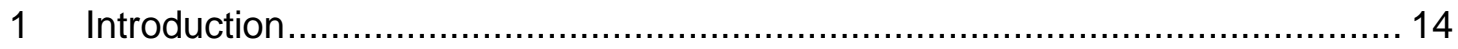

1.1 New Zealand and overseas work …………................................... 18

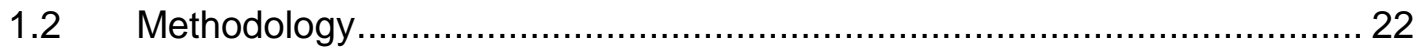

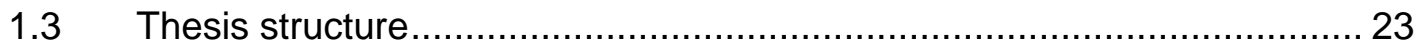

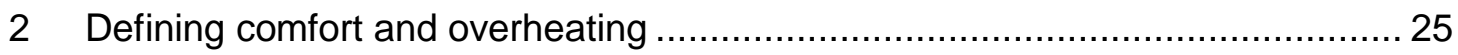

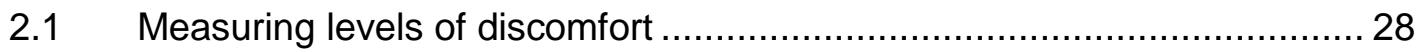

3 Evidence of overheating in New Zealand houses …….................................... 32

3.1 Temperatures during summer in New Zealand houses.............................33

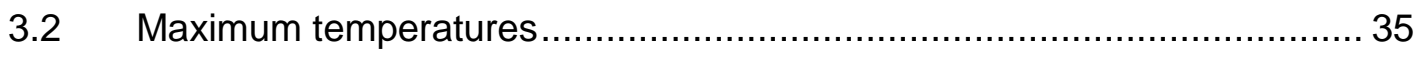

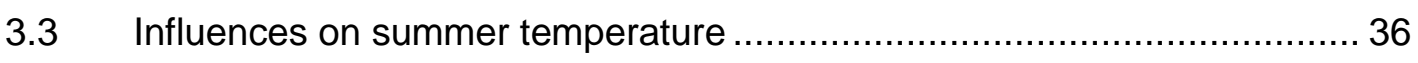

3.4 Temperature measurement in the monitored houses ............................. 42

4 New Zealand's climate - is overheating expected?........................................... 44

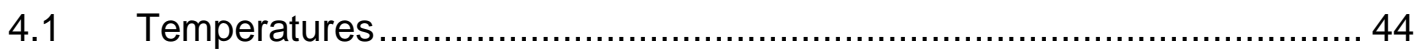

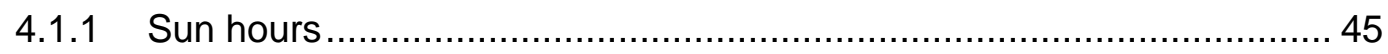

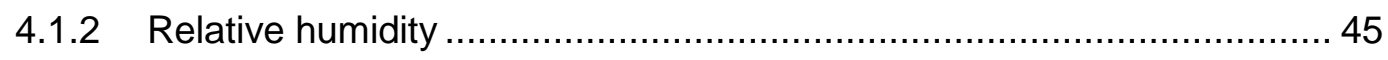

4.2 Climate change and New Zealand...................................................... 46

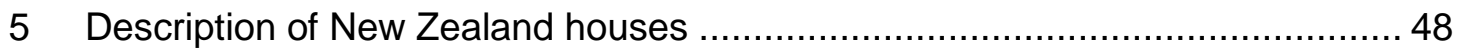

5.1 New Zealand Building Code .................................................................. 49

$5.2 \quad$ House age

5.3 How are houses changing overtime? ..................................................... 51

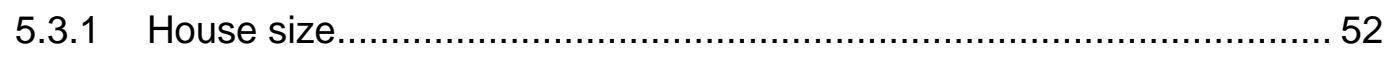




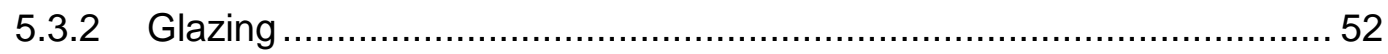

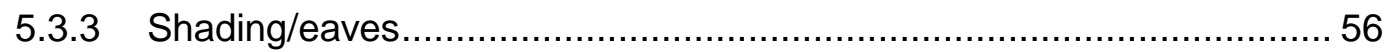

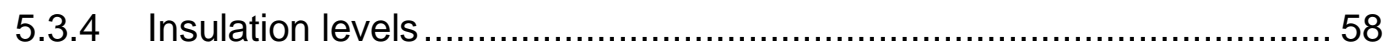

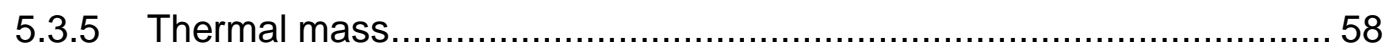

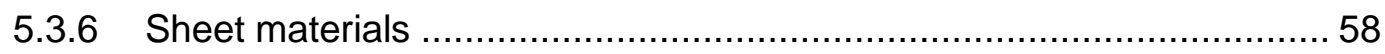

5.3.7 Airtightness and infiltration................................................... 59

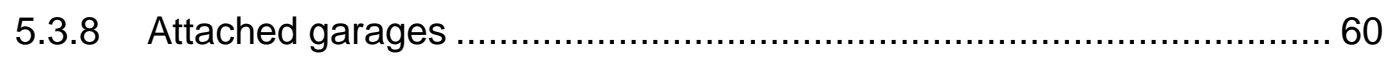

6 Features contributing to overheating - literature review ............................ 61

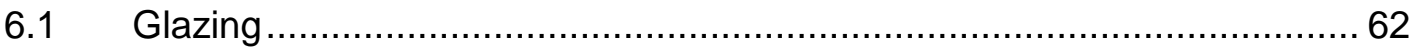

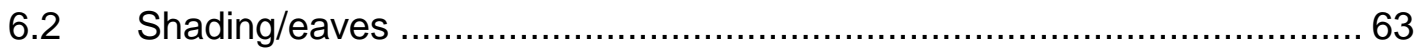

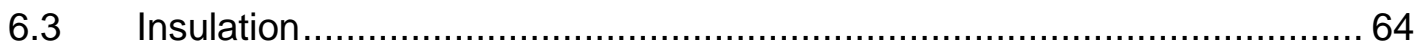

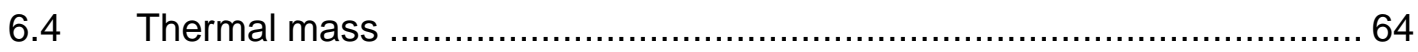

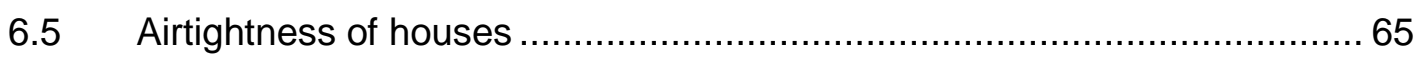

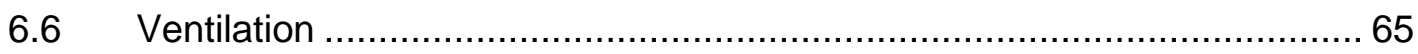

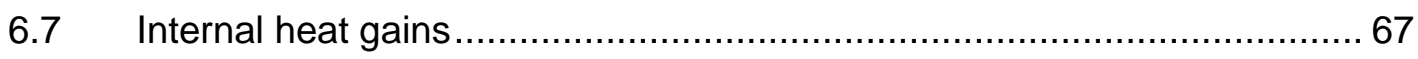

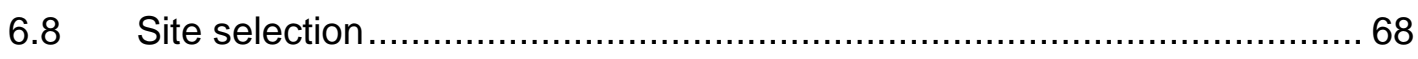

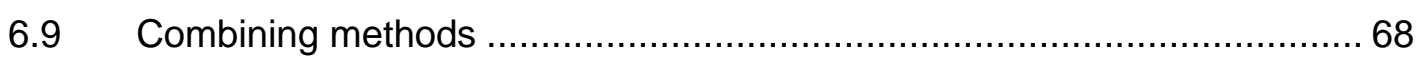

7 Thermal modelling to determine which features contribute to overheating ........69 69

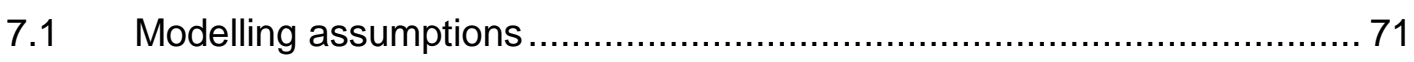

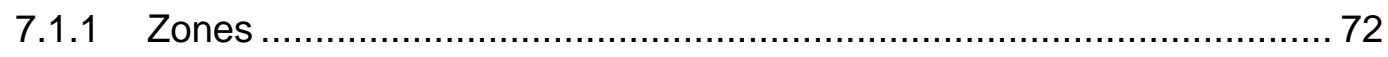

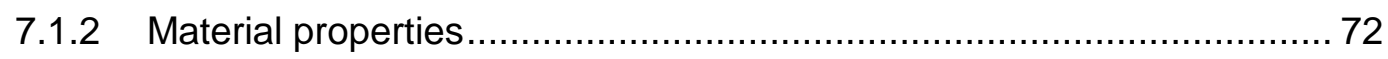

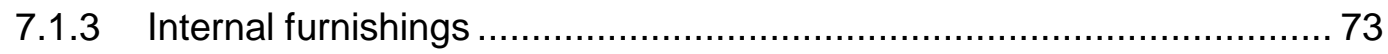

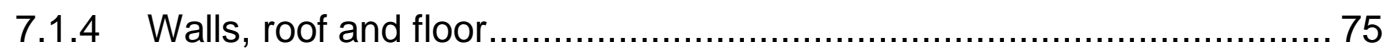

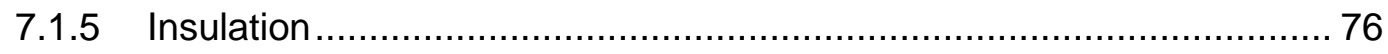

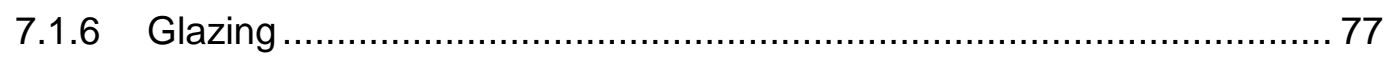

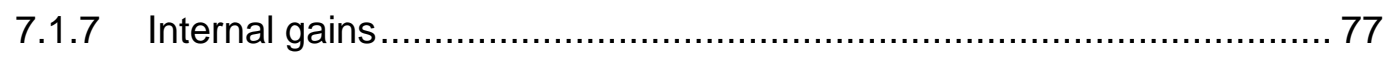




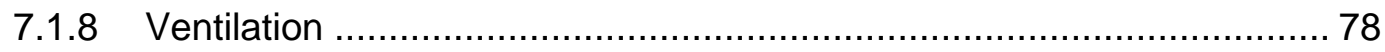

7.1.9 Air leakage/infiltration ....................................................... 78

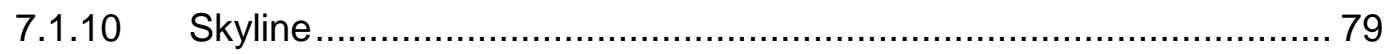

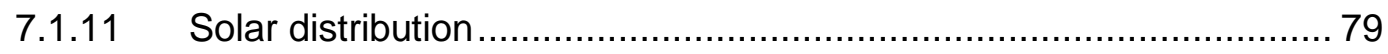

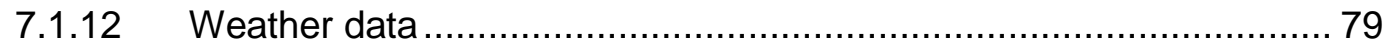

Calculation of temperature in models .......................................... 82

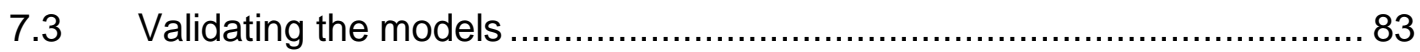

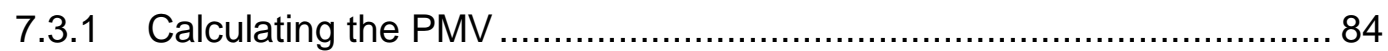

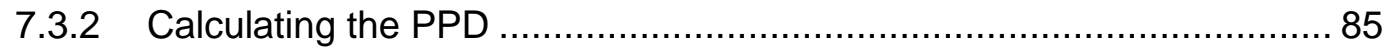

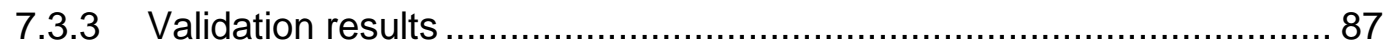

8 Changes in design and construction that are causing overheating ................... 90

8.1 Results from monitored data....................................................... 91

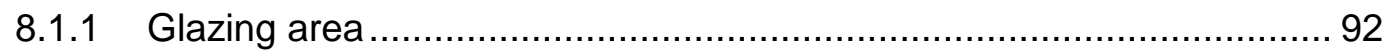

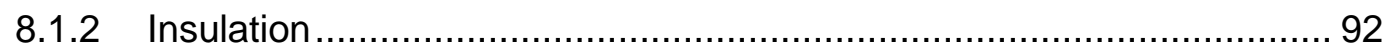

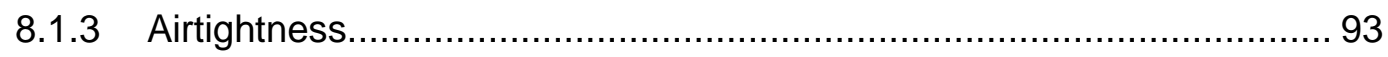

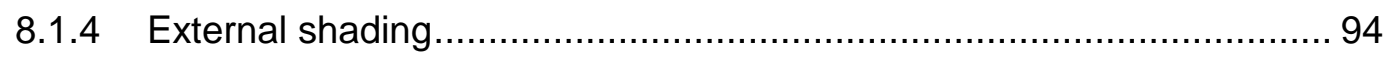

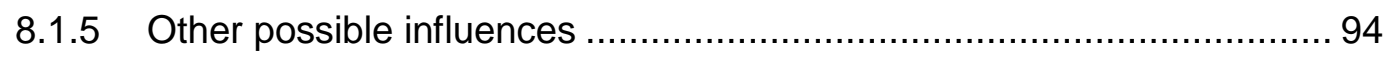

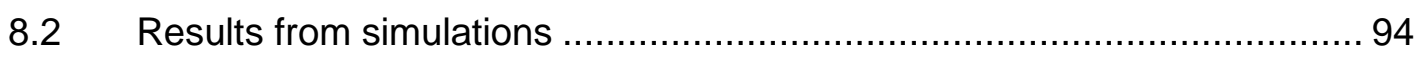

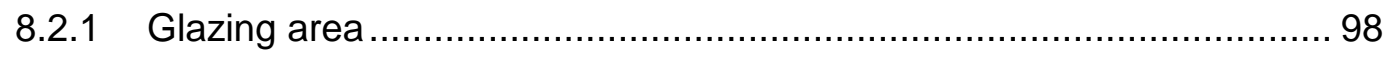

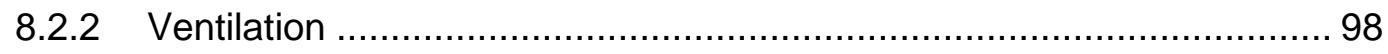

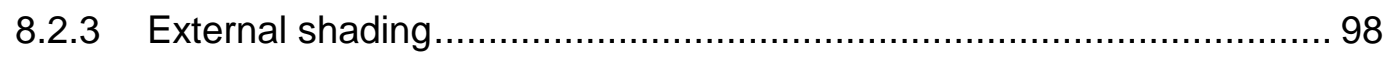

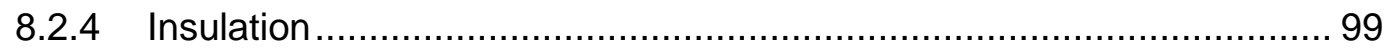

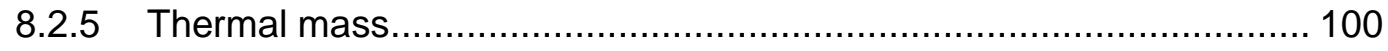

9 Discussion on design and construction features causing overheating ............. 102

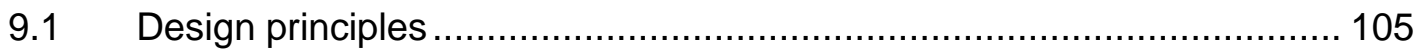

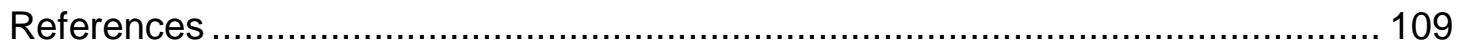




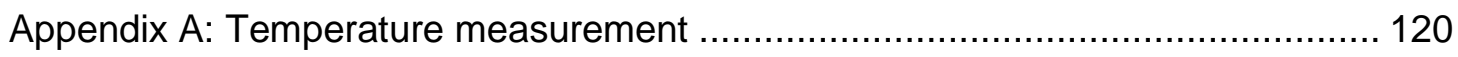

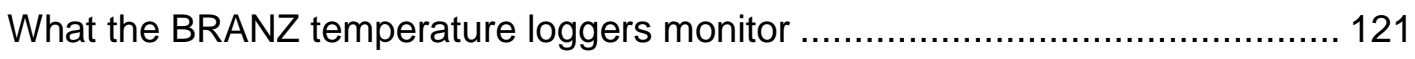

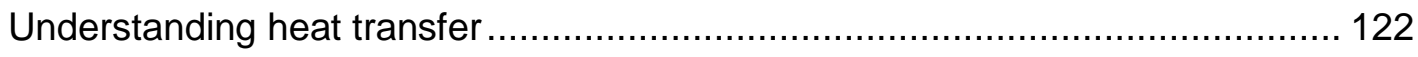

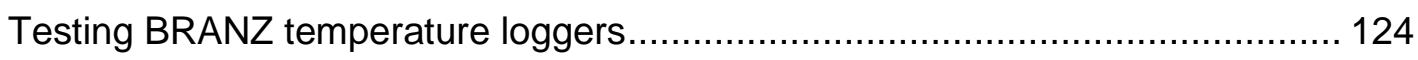

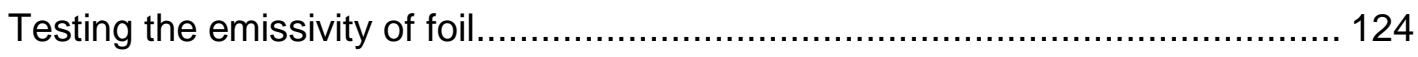

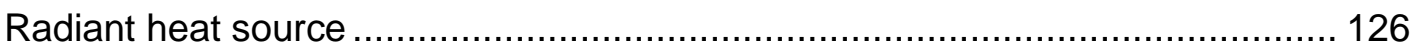

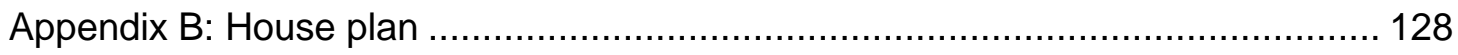

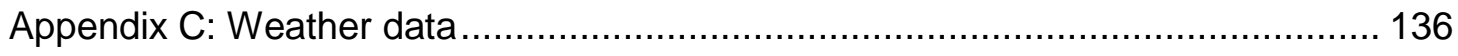

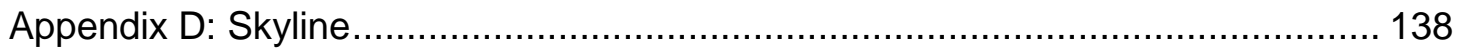

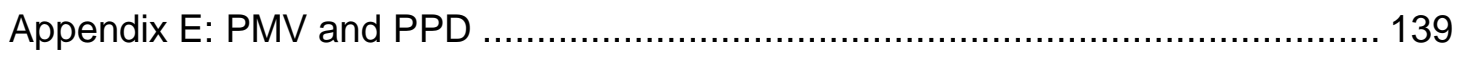




\section{Figures}

Figure 1: Heat pumps and wood burners in Perth, Australia (Australian Bureau of Statistics 2008)

Figure 2: Acceptable range of operative temperature and relative humidity 30

Figure 3: Acceptable operative temperatures for naturally conditioned spaces ........ 31

Figure 4: Average time in specified temperature ranges - summer $4 \mathrm{pm}$ to $6 \mathrm{pm} \ldots . .33$

Figure 5: Living room evening summer temperature 34

Figure 6: Mean living room daytime temperatures 34

Figure 7: Maximum temperatures reached in New Zealand houses 36

Figure 8: Mean summer living room daytime temperatures by Regional Council ..... 37

Figure 9: Summer temperatures by house age 39

Figure 10: North Island climate zones and HEEP locations 39

Figure 11: South Island climate zones and HEEP locations 39

Figure 12: New dwelling consents 49

Figure 13: Counts of house by age (Quotable Value 2007)..... 51

Figure 14: Early 1900s house 52

Figure 15: Mid-1900s 52

Figure 16: Post-2000 house. 52

Figure 17: Pre-1900 house (Lincoln College 1975) .............................................. 55

Figure 18: 1950s house (Lincoln College 1975) ................................................. 56

Figure 19: 1950s house (Lincoln College 1975) ................................................ 56

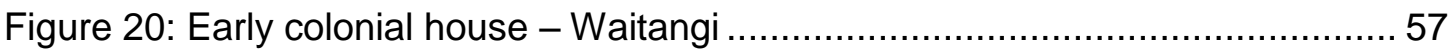

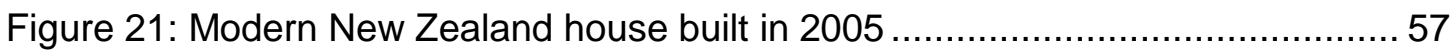

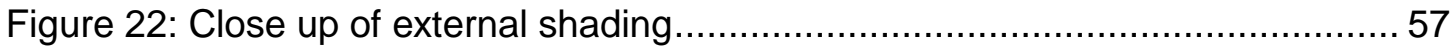


Figure 23: Histogram of air change rates at $50 \mathrm{~Pa}$ for $40 \mathrm{New}$ Zealand houses (Bassett 1992) 60

Figure 24: PMV and PPD relationship (Innova 2007) 85

Figure 25: PPD for House one - first 300 hours of January 87

Figure 26: PPD correlation for House one - PPD 88

Figure 27: Temperature correlation $\left({ }^{\circ} \mathrm{C}\right)$ - House one 88

Figure 28: Mean living room day temperatures by insulation requirements 92

Figure 29: Increasing and decreasing maximum temperatures 97

Figure 30: A BRANZ temperature logger (right) with a Tiny-tag temperature logger 120

Figure 31: Heat flow meter - testing the emissivity of foil................................ 125

Figure 32: Loggers and radiant heaters .................................................... 126

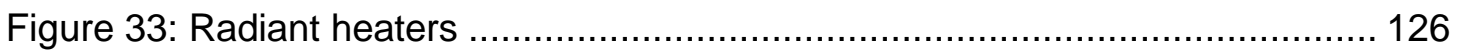

Figure 34: Temperature measurement during 30 minutes of the heater on ............ 127

Figure 35: Temperature measurements during three cycles of the heater on......... 127 


\section{Tables}

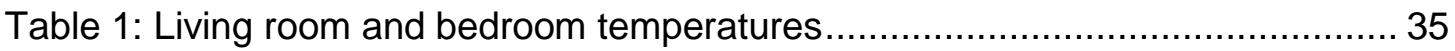

Table 2: Living room and external evening temperatures by house age.................. 40

Table 3: Summer evening living room temperatures ...................................... 41

Table 4: Daily mean maximum and minimum temperatures over summer .............. 41

Table 5: Missing data - Tiny-tag and BRANZ temperature loggers ....................... 42

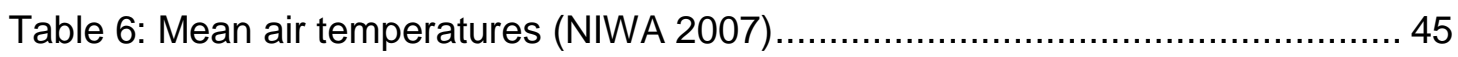

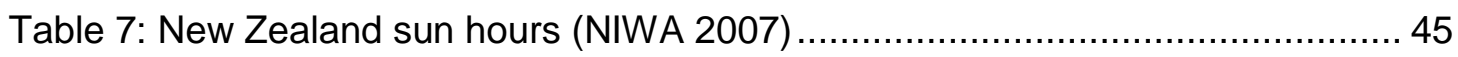

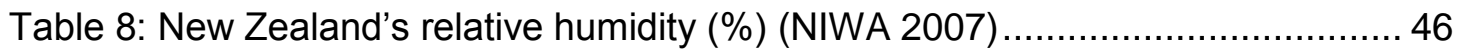

Table 10: Building Code thermal performance requirements 1978 to current...........50

Table 11: Solar glazing and house age - HEEP …...................................... 53

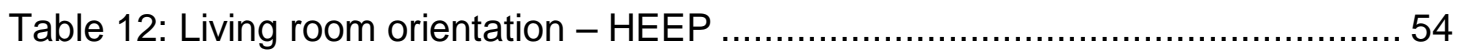

Table 13: Description of houses modelled .................................................. 71

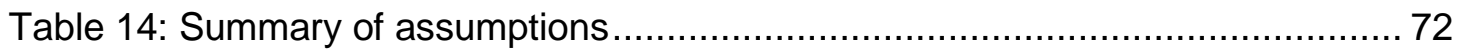

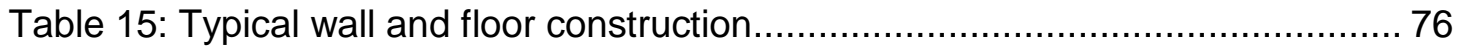

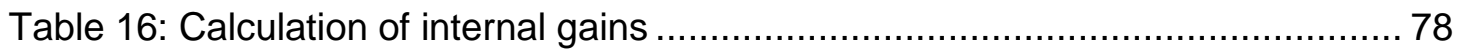

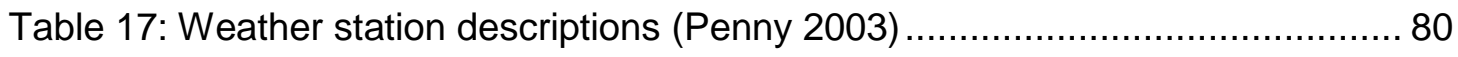

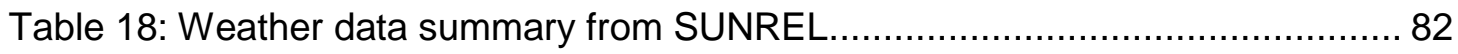

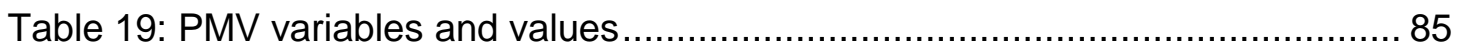

Table 20: An example of calculated PMVs and PPDs ................................... 86

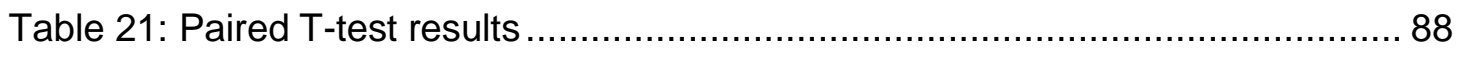

Table 22: Mean living room temperatures by insulation requirements .................... 93

Table 23: Airtightness and living room temperature ....................................... 93

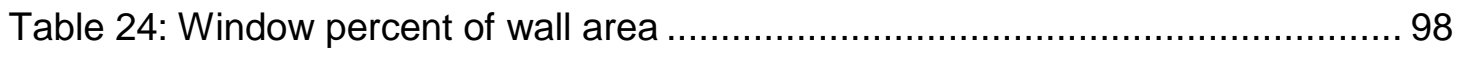




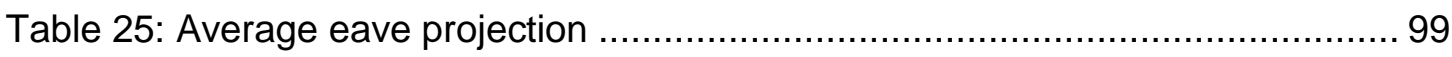

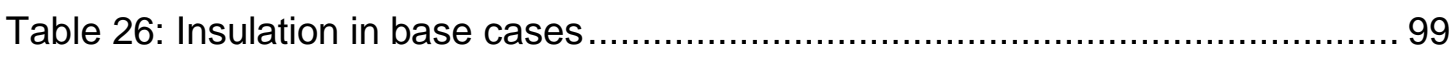

Table 27: R-value of insulation for Code and high insulation tests in models ......... 100

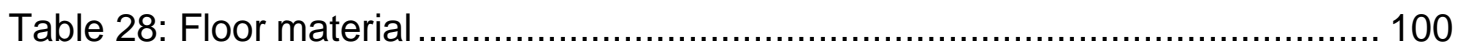

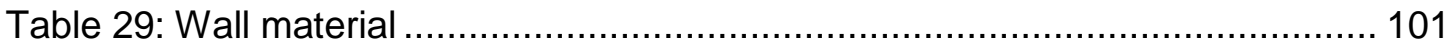

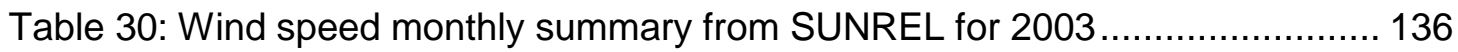

Table 31: Solar radiation monthly summary data from SUNREL for $2003 \ldots \ldots \ldots \ldots . . . .137$

Table 32: Descriptions and assumptions used to calculate PMV and PPD ............ 143 


\section{Introduction}

Analysis of temperature data from real New Zealand houses has shown houses built today are $2.5^{\circ} \mathrm{C}$ warmer in summer than those built a century ago (French et al 2007a). The amount of overheating that is occurring due to increasing temperatures is significant. For example, an average 1990s house is spending $40 \%$ of the time between $4 \mathrm{pm}$ and $6 \mathrm{pm}$ above $25^{\circ} \mathrm{C}$ in summer - this is an uncomfortably hot temperature. Although it can be argued that occupants will move to the outdoors to avoid these uncomfortable temperatures, it is important we are able to design and build houses that are comfortable at all times. To prevent houses from overheating, it is important to understand the changes in design and construction that have led to new houses being warmer.

For this work, features that have changed in new houses and are known to influence temperature have been examined to determine their influence in New Zealand houses. The influence of each feature on temperature was examined in both monitored data from real houses and thermal models. The models were validated against data from the monitored houses to ensure the results can be applied with confidence. Modelling has the advantage of being able to change one feature at a time to determine its influence. Once the features having the greatest influence on temperatures are known, design guidance can be inferred, and the option of regulation can be considered to reduce the likelihood in future of uncomfortable indoor temperatures in summer.

There are several reasons why it is worthwhile knowing what is causing the summer temperatures to increase in new houses. There is concern that occupants will find their houses uncomfortable and use active cooling. The potential of this happening is 
increased by New Zealand currently experiencing a rapid increase in installations of reverse cycle air-conditioners (heat pumps) for heating, which are also able to cool. Taking the opposite view, if a house is overheating and occupants choose not to use active cooling (or are not able to because of money constraints), there is the potential for occupants to be uncomfortable in their houses. Traditionally few New Zealand houses have had the ability to cool. With the rapid update of heat pumps it is now possible in almost $20 \%$ of houses, with as many as $60 \%$ of households choosing to do so (French 2008).

Once the technology is installed for active cooling, it becomes a very convenient and effective option. Heat pump manufacturers have slogans such as "if you can build it we can air-condition it" (Buckett 2007). Heat pumps give the user the impression they are solving the problem of overheating, by doing something about it. But they do use electricity, when potentially a good design may have stopped the house from overheating in the first place. There are currently many unknowns with what to expect for electricity use from active cooling. This is an issue for electricity planners and their demand forecasting. Technological advancements and standards for energy efficiency of heat pumps ensure they are efficient, but no plan has been put in place so heat pumps can be shut down for short periods at times of peak demand.

Last year alone approximately $160 \mathrm{MW}$ worth of heat pumps were installed into residential homes. The Government Energy Minister Hon. David Parker reports total New Zealand electricity demand is expected to grow by about $20 \%$ by 2025 , requiring an extra $3500 \mathrm{MW}$ of additional generation (Mole 2008). This is a per year growth of approximately $200 \mathrm{MW}$. This indicates that new electrical generation plant will be required just to cope with the growth in heat pumps. The government's push for the 
country to reduce carbon emissions limits the options available for generation of electricity. The increase in electricity use will also place pressure on transmission and distribution and may fast forward the need for upgrades in some areas. The time the maximum temperature is reached in homes varies from $5 \mathrm{pm}$ to $6.40 \mathrm{pm}$. This is a time of peak demand and the potential load from active cooling could be very significant.

The need for electricity system capacity upgrades will ensure electricity prices continue to rise. Having a house that relies on electricity to be comfortable during summer will therefore be a large problem for many. Reliance on heat pumps also means a reliance on the electricity network. Given the large number of houses overheating for a short period each day, the chances of a large number of heat pump households all cooling at the same time is high. A large demand placed on the electricity network at the same time raises the risk of failure of the system. Investing in power generation to cover the risks caused by this very short-term peak is an extremely expensive exercise.

The New Zealand government through the New Zealand Energy Efficiency and Conservation Strategy is focused on improving the energy efficiency of homes (EECA 2007). Heat pumps fit into this strategy as they are an efficient form of heating. However, if they are used for cooling these heat pumps add a new load for New Zealand which fights against the aims of the strategy.

Through temperature monitoring of a representative sample of New Zealand houses, it is known that climate has the largest effect on summer indoor temperatures followed by house age (French et al 2007b). Due to the strong influence of climate on indoor temperatures, the expected temperature increases from climate change is a concern; it is a compounding effect of newer houses overheating. Data analysis shows that for 
each external temperature increase of $1^{\circ} \mathrm{C}$, the mean house temperature increases by $0.8^{\circ} \mathrm{C}$ (French et al $2007 \mathrm{a}$ ). Therefore from a $3^{\circ} \mathrm{C}$ temperature rise (possible through climate change), we can expect on average our houses to be $2.4^{\circ} \mathrm{C}$ warmer. If the climate in New Zealand gets warmer, overheating will therefore be even more of an issue.

When building or buying a newly constructed house, occupants have the right to high expectations for performance. It is realistic to expect that the house will be more comfortable than their previous house. With the current trend of new houses increasing in temperature in summer, the occupants could be disappointed with an overheating house. Ideally a house is designed to shelter the occupants from the elements, keep them safe, be durable and cost as little as possible to run. At present the majority of houses are being built without considering overheating as an issue. This is a trend that needs to be altered.

It is important houses today are energy efficient and sustainable for the future. However, houses today have the potential to force occupants to rely on electricity to be comfortable, and this is a step backwards for New Zealand. Understanding why newer houses are warmer in summer will ensure cooling is not the only option for comfort, now that cooling is more assessible. This will mean houses are not reliant on energy to be comfortable.

Understanding what features of new houses are causing overheating will strengthen the ability to design houses that will be comfortable in summer, without relying on energy. Policy makers will be able to consider comfort standards and regulation to prevent overheating. At present there are no standards for comfort in New Zealand, 
and the housing energy efficiency standard is currently focused on winter heating. The current requirements (DBH 2007) also limit the amount of glazing a house can have. The glazing cannot be more than $30 \%$ of the wall area, unless insulation is increased sufficiently in other elements. Although this rule should reduce solar gains, it was set with the intention of reducing heat losses in winter. The energy efficiency standard has recently been revised with increased insulation requirements. The work done in this thesis will help to understand the effects increased insulation will have on summer temperatures. The information will then be available to prevent overheating occurring and cooling being necessary for comfort.

\subsection{New Zealand and overseas work}

The following section gives an overview of New Zealand and overseas work in relation to summer overheating and cooling use.

New Zealand is unique in that it has a good database of 397 house temperatures and energy use through the HEEP project. The database also holds information on house audits and occupant surveying allowing influences on temperatures to be determined (Isaacs et al 2005, Isaacs et al 2006). New Zealand has the data to understand and prevent issues with residential houses. The HEEP data has been used in this work to determine influences on summer temperatures and to understand the New Zealand housing stock. New Zealand is the only country known to have a database with measured temperature and energy data from a representative sample of houses. No studies have examined the causes of increasing temperatures through monitored data.

Chapter 2 discusses the temperatures occupants find comfortable. There has been little work done on comfort in New Zealand. However, there have been many studies 
overseas which can give an indication of when New Zealanders are likely to feel comfortable. A number of studies including Nicol and Humphreys (1998). Brager and de Dear (2001) and Baker and Standeven (1996) suggest that an acceptable internal temperature for passive buildings depends on their environment as occupants adapt to the climate and building (adaptive temperatures). International work also suggests comfort relates to more than just temperatures.

There are several other factors that affect people's comfort including relative humidity $(\mathrm{RH})$, air speed, clothing and activity levels (ASHRAE 2004). No national studies have been done on comfort in New Zealand, although two pilot studies of comfort temperatures have been completed by students at Victoria University of Wellington (Smith 2007 and Yoo 1998). The pilot studies suggest that the temperatures that occupants find comfortable in New Zealand are affected by the ambient temperature. Given New Zealand's relatively mild climate the upper limit for comfort is likely to be less than in warmer countries internationally.

There are two main comfort standards: International Standard Organization 7730 (2005) and ASHRAE 55 (2004). In the ISO standard (ISO 7730:2005) the Predicted Mean Vote (PMV) and the Predicted Percentage of People Dissatisfied (PPD) is used. ASHRAE 55 (2004) looks at the PMV and PPD method and adaptive temperatures. Section 2 goes into more detail about comfort standards and comfort research.

There is concern in the UK about the effects of increasing insulation levels on summer indoor temperatures. Orme and Palmer (2003) conducted a modelling study looking at how to control overheating in UK houses. They found it was necessary to control solar gains, thermal mass, ventilation and internal gains for highly insulated houses. They 
also found that combining measures for controlling temperatures worked very effectively. Orme and Palmer (2003) present design guidelines in relation to solar gains, thermal mass, ventilation and internal gains.

Climate change is considered an issue in New Zealand, and Jacques (2000) has looked at how to mitigate climate change effects in housing. He reports on modelling work where he has examined different climate scenarios and building parameters affecting overheating. The results are reported as overheating hours. Jacques found climate to be the most important factor in indoor temperature, which is confirmed by French et al (2007b). Jacques found the ventilation rate to have a large effect on the indoor temperature. This study looked at three houses - all with the same construction, insulation levels and assumptions - varying only by size. Jacques goes on to explore calculations for determining maximum temperatures reached in houses.

Australia like New Zealand is experiencing a rapid increase in the number of heat pumps. Often they are being installed for cooling, but used for heating as well. The quick growth of heat pumps and the reduction of wood burners in a location with clean air regulations can be seen in Figure 1. This graph demonstrates how quickly the type of heating energy required can change. Due to the increase in heat pumps in Perth, they are struggling to cope with peak electricity loads. This has resulted in education campaigns to lower electricity use between $3 \mathrm{pm}$ and $6 \mathrm{pm}$ (this is mainly a problem during summer). Australia is more advanced with cooling and the uptake of heat pumps than New Zealand, giving this country the opportunity to learn from them. 


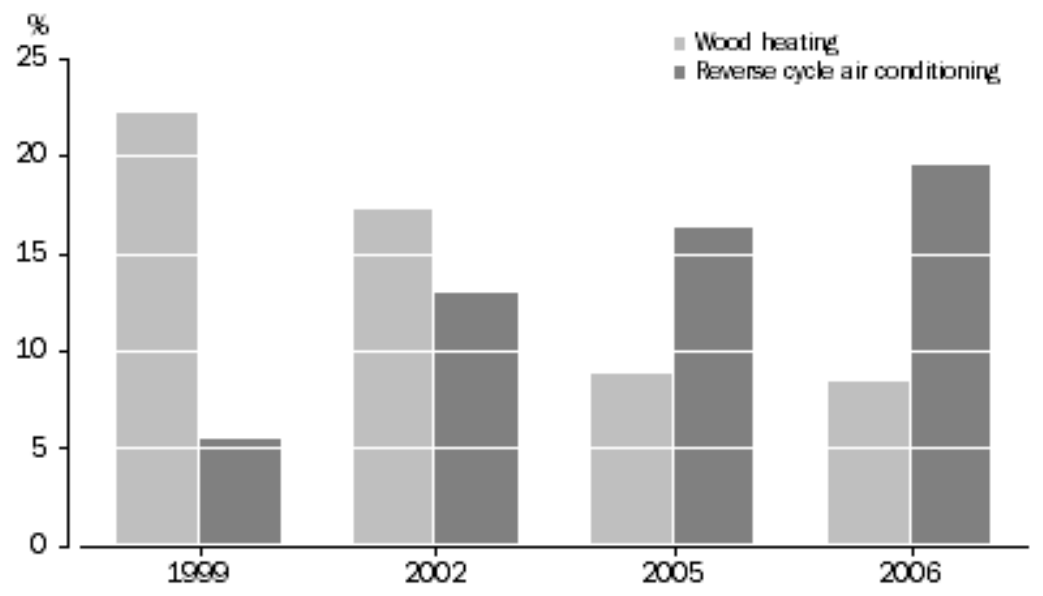

Figure 1: Heat pumps and wood burners in Perth, Australia (Australian Bureau of Statistics 2008)

The literature examined in Chapter 6 provides an indication of what features have an influence on temperatures. There are variations between the recommended best ways to effectively reduce temperatures, suggesting there is variation between houses, climate, occupants and combinations of design. The key features that were found to influence temperatures were the level of ventilation, glazing area and orientation, external shading, infiltration, thermal mass, site selection, insulation levels and the amount of internal gains.

The work that has been completed for this thesis is unique as it uses temperature data from real houses and validated thermal models. Australia is experiencing similar issues to New Zealand with the uptake of heat pumps and cooling, but they do not have the advantage of a temperature dataset of representative houses. New Zealand does, and this work is one way of using this data to understand the influences the design and construction of our houses have on comfort and energy use. 


\subsection{Methodology}

The following section gives an overview of the methodology used to determine the design and construction parameters, which are causing summer temperatures in new houses to increase.

First, a literature review was undertaken to examine how house design and construction has changed over the years in New Zealand. This work was supported by examining the HEEP database which holds house audit information for 397 houses throughout New Zealand.

To understand what features of design and construction are important for passive cooling and heating, further literature was reviewed. This review found house features that influence indoor temperatures and could be further explored.

Analysis was undertaken on the HEEP database to examine the influences of important features. There were issues encountered by using data from real houses. It is difficult to achieve statistically significant results in many cases, due to the large variations between houses and how they are used. For this reason thermal modelling was completed to support results found in the real houses.

Thermal modelling allows control over the occupant influences and the features of each house. The results from the models were validated against the monitored temperatures from the real houses. With the validated models one feature at a time was changed and the temperature compared to the base model. The temperatures compared were the average daily maximum for the first three weeks of January 2003. 
The results of the modelling and the analysis of the monitored data allowed the key features causing an increase in indoor temperature to be determined.

Design guidelines for new houses and suggestions to reduce overheating in existing houses are made using the information from thermal models and monitored data analysis.

\subsection{Thesis structure}

The following section gives an overview of each chapter in the thesis.

Chapter 1 has explained the reasons for this work, given the context and an overview of the methodology.

Chapter 2 discusses comfort standards and what temperatures are considered comfortable, to give a reference for which temperatures are too hot.

Chapter 3 gives background to the study through exploration of the temperatures from analysed data measured in 397 houses in New Zealand. Using this data the influences on temperatures in houses are found.

Chapter 4 gives a description of the New Zealand climate, showing active cooling should not be necessary.

Chapter 5 explores the changes that are happening in the design and construction of New Zealand houses. The changes are explored through literature and the HEEP database. Using the database changes can be seen such as increasing floor areas and 
amounts of glazing. It also shows good design for passive heating or cooling is not being done.

Chapter 6 gives a literature review on passive design for controlling the temperature in houses. The information in this chapter is used to determine which features are important and is explored further through modelling and analysis.

Chapter 7 explains the process of validating the thermal models and shows the results of this validation. Modelling assumptions are also given. The validation process uses the PPD method; therefore the method of calculating both the PPD for the models and the houses are explained.

Chapter 8 explores the causes of temperature increases through the HEEP database and modelling. This chapter gives the results for what features of new houses are causing indoor temperatures to increase during summer.

Chapter 9 discusses the conclusions of this work. There is a discussion on how to prevent the trend of increasing temperatures in new houses. Good design suggestions are given, as well as ideas for changes to building regulations to prevent overheating in houses. 


\section{Defining comfort and overheating}

It is important to understand what is considered comfortable to determine when a New Zealand house is too hot or overheating.

ASHRAE's definition of comfort is "the condition of mind that expresses satisfaction with the thermal environment; it requires subjective evaluation" (ASHRAE 55 2004).

Thermal comfort is not just dependent on air (dry-bulb) temperature. The $\mathrm{RH}$, surface temperatures in the space, air velocity, clothing and activity level of the occupants, and mean radiant temperature also influence comfort. Age and gender have been found to affect thermal preferences. The elderly tend to have a narrower comfort range. Women usually prefer a higher temperature to men, although this may be because of clothing differences (Auliciems and Szokolay 1997).

For this work air temperatures are being looked at for overheating. Auliciems and Szokolay (1997) suggest the dry-bulb temperature is the most useful measure for comfort, but for measuring the magnitude of discomfort or stress a measurement that recognises $\mathrm{RH}$, radiation and air movement is needed. This work is limited by the data available. Only dry-bulb temperatures were monitored in the available house database. However a good indication of overheating can be found from dry-bulb temperatures.

Most comfort work internationally has been undertaken in office buildings. It has been assumed for this research that differences should be small between passive occupantdriven office buildings and passive occupant-driven houses. 
Internationally there are two methods used to determine what temperatures are comfortable for occupants. First, field studies where occupants are asked how they would rate their comfort - normally using a seven or nine-point scale. The conditions affecting comfort (air speed, clothing etc) are also measured (e.g. Humphreys and Nicol 1998 and Brager and de Dear 2001). The second method uses climatically controlled chambers, where the occupants rate how they feel in a climate controlled space (Fanger 1970). Often the results from the climate chamber work find a narrower comfort range, compared to the comfort range for occupants in houses or offices. This is thought to be due to occupants adapting to their environment and being more forgiving if they have some control over their environment. Fanger (1970) developed the PPD method using results from climate chamber research. His work found $5 \%$ of people will always be dissatisfied. The PPD method is used in two international standards: ASHRAE 55 (2004); and ISO 7730 (2005).

Because of this growing knowledge about comfort adaption, it is important to understand what temperatures New Zealanders find comfortable, rather than just looking at overseas suggested ranges. The field studies indicate that acceptable comfort temperatures in passive, occupant-driven buildings vary depending on the average outdoor temperatures. Due to the mild climate in New Zealand it is expected the comfort range may be lower than in warmer overseas countries. The upper limit is also expected to be lower. However, studies have found the more extreme the temperature (either hot or cold) the more aligned the responses to comfort become (Rohles 2007). This suggests the upper limit differences between tropical and milder climates may not be that large. Rohles also found the more dissatisfied occupants are with their built environment surroundings, the less likely they will be thermally satisfied. 
In New Zealand two pilot field studies have been done on comfort by university students. One year-long study in 2007 by a Building Science Honours student measured temperatures and occupant comfort responses in nine houses in Papakowhai, Wellington (Smith 2007). The temperature occupants found to be most comfortable over the year was $19.6^{\circ} \mathrm{C}$. The focus of this study was on heating and asked "what were the temperatures below which the occupants wanted to turn on the heating?" However, there was a large seasonal variation from approximately $17^{\circ} \mathrm{C}$ in winter to $21^{\circ} \mathrm{C}$ during summer. This work supports the international work on occupants' comfort being driven by the external temperature. The second study (Yoo 1998) found the physical characteristics of the dwelling to have an influence on the occupants' response to comfort, aligning with Rohles' (2007) work mentioned earlier.

No national studies have been completed in this country to determine what temperatures are too hot for New Zealanders. Previous work has made assumptions based on international research such as 'above $25^{\circ} \mathrm{C}$ is overheating' in climate change studies by Jaques (2000) and Camilleri (2000). Donn and Thomas (2001) agree, suggesting uncomfortably hot to be $25^{\circ} \mathrm{C}$ or over, uncomfortably cold to be $16^{\circ} \mathrm{C}$ or under, leaving the comfort range between $16^{\circ} \mathrm{C}$ and $25^{\circ} \mathrm{C}$. Stevens (1982) suggests occupants should be comfortable between $16^{\circ} \mathrm{C}$ and $26^{\circ} \mathrm{C}$. For this work 'too hot' is therefore considered to be $25^{\circ} \mathrm{C}$ or above, well below $21^{\circ} \mathrm{C}$ which Smith (2007) found occupants to be most comfortable at during summer. This is in line with the World Health Organisation suggested optimum comfort range of $18-25^{\circ} \mathrm{C}$ (WHO 2003). In reality it is possible that temperatures below $25^{\circ} \mathrm{C}$ are still uncomfortably warm for occupants during summer. It is also possible some people will be comfortable above $25^{\circ} \mathrm{C}$. 
Oseland and Humphreys (1994) show that in the UK it is not uncommon to find a reversal of seasonal temperatures - rooms being cooled in summer to temperatures lower than those to which they are heated in winter. It is possible for households that are heating efficiently in their well-insulated home with a heat pump, then to use the heat pump to cool in the summer. Humphreys (1978) suggests summertime comfort is an air temperature between $20^{\circ} \mathrm{C}$ and $24^{\circ} \mathrm{C}, \mathrm{RH}$ between $40 \%$ and $60 \%$ and surface temperatures of nearby objects not differing from the air temperature by more than 2$3^{\circ} \mathrm{C}$.

In the UK Orme and Palmer (2003) have used above $27^{\circ} \mathrm{C}$ to be considered too hot. Orme has also done work on overheating in schools. Overheating has been found to occur when the temperature difference between inside and outside is too great. Guidelines in New South Wales (NSW), Australia (University of Sydney 2008) suggest an optimal temperature range of $21^{\circ} \mathrm{C}$ to $24^{\circ} \mathrm{C}$ in the summer and an acceptable range of $20^{\circ} \mathrm{C}$ to $26^{\circ} \mathrm{C}$. Internationally the maximum temperature has been found to range from $24^{\circ} \mathrm{C}$ to $27^{\circ} \mathrm{C}$.

Given the international and national work completed $25^{\circ} \mathrm{C}$ and above is considered a realistic upper limit for comfort in New Zealand for our mild climate.

\subsection{Measuring levels of discomfort}

Even with setting $25^{\circ} \mathrm{C}$ as 'too high' some people will still find this comfortable, depending on their preferences and other conditions that affect comfort $(\mathrm{RH}$ etc). But at around this level we would expect $80 \%$ dissatisfaction. So the PPD / PMV standard approach allows quantification of this as explained. 
At present there is no New Zealand standard for comfort in buildings. Internationally the key comfort standards for buildings (others exist for vehicles and the sick or disabled) are ASHRAE 55 (2004) and ISO 7730 (2005). Both methods are designed for commercial spaces, however where relevant the definition of overheating is aligned with this work.

In ISO 7730 (2005) the PPD method is used for calculating comfort; in ASHRAE 55 (2004) both the PPD method and adaptive temperatures are used. The use of PPD has not been validated in the field (Oseland and Humphreys 1994), although it has been found to work well in a controlled environment. However, the differences in results between field studies and climate chambers are not well understood. PPD has been generally accepted and is used but is not verified. Verifying the method is not easy, due to the difficulties in measuring radiation, air speed, clothing and metabolic rate, which change with time. The PPD method has been developed in steady state conditions and is, therefore, only suitable for environments where climatic changes are gradual.

The American Society of Heating, Refrigeration and Air-Conditioning Engineers (ASHRAE) Standard 55:2004 has two methods available for compliance. Up until the latest revision of the standard only the PPD method was available. The latest standard (2004) recognises adaptive temperatures for naturally ventilated spaces and offers a method of compliance for commonly designed spaces.

In ASHRAE 55 (2004) the PPD is used to generate a range of acceptable conditions on the psychrometric chart so that at least $80 \%$ of occupants are satisfied. There is also the option of using the supplied computer code to calculate the PPD for different 
conditions that are given e.g. different metabolic rates. This method also covers local thermal discomfort due to difference in air temperature, radiant temperature drafts etc. ASHRAE 55 (2004) uses the psychrometric chart (Figure 2) from 1966 for their definition of the comfort zone. The definitions of the boundaries have been altered many times, including in the latest revision of the standard in 2004 . The psychrometric chart considers the air temperature (dry-bulb temperature), $\mathrm{RH}$ (wet-bulb temperature), radiation and air speed.

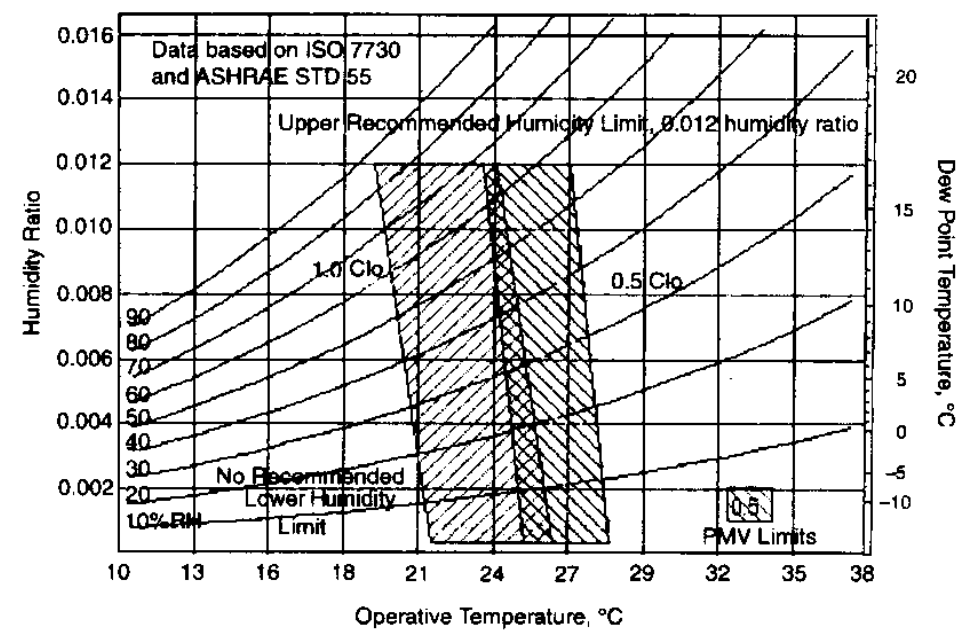

Figure 2: Acceptable range of operative temperature and relative humidity

The second method in ASHRAE 55 (2004) is based on adaptive temperature principles (external temperature affects indoor comfort). This method is only able to be used for naturally ventilated buildings through opening and closing windows. Field studies show thermal response can vary to those in HVAC controlled buildings and the outdoor climate. Occupants must be able to freely change clothing and have low activity levels (metabolic rates between 1.0 met and $1.3 \mathrm{met}$ ). Buildings need to meet the requirements so $80 \%$ of the occupants should be satisfied; for buildings where a high standard of thermal comfort is required they should meet the $90 \%$ level (Figure 3 ). The requirements are based on an adaptive model of thermal comfort from a global 
database of 21,000 measurements taken primarily in office buildings. Occupants are expected to adjust their clothing levels to suit the temperature. The air speed and the $\mathrm{RH}$ limits are required to be met when using this method. Local discomfort does not have to be considered.

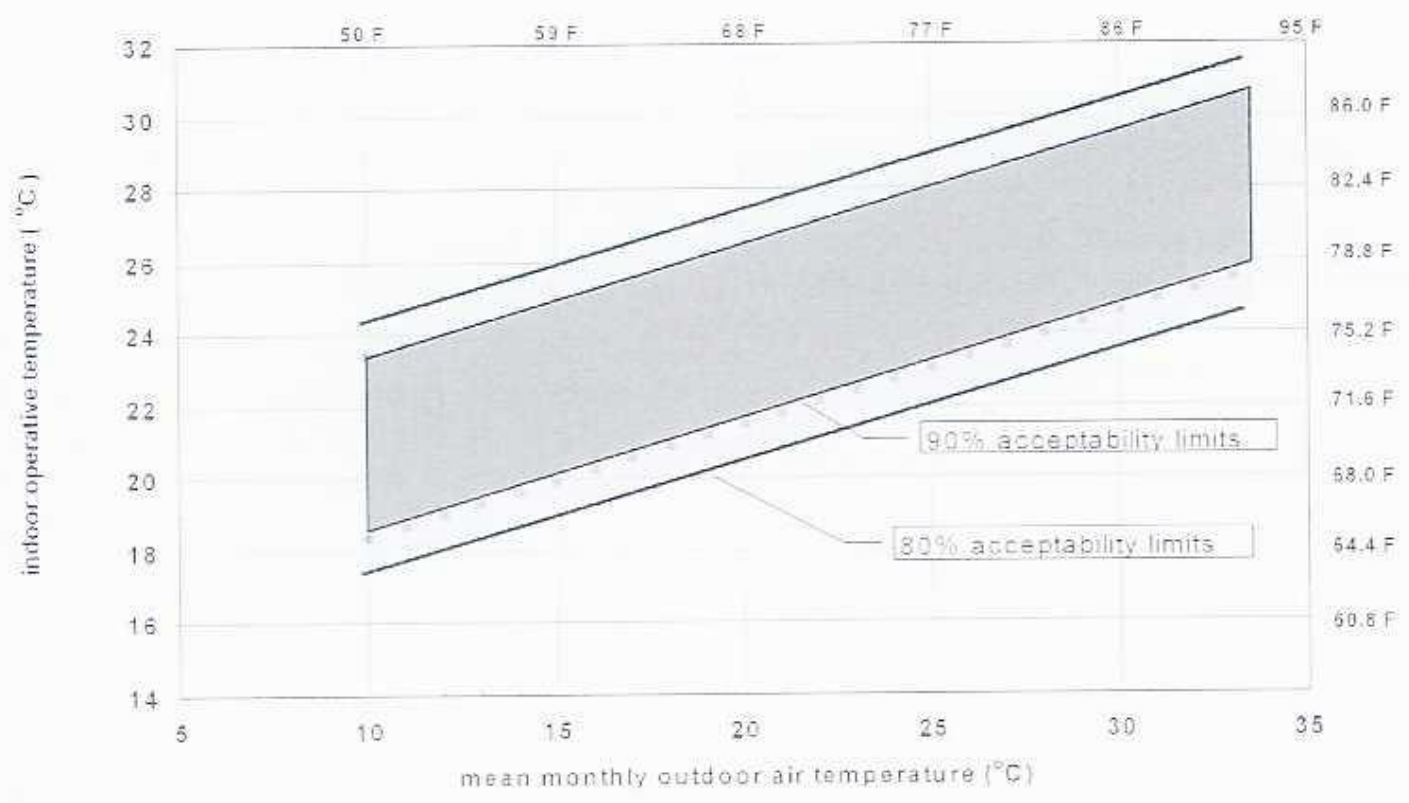

Figure 3: Acceptable operative temperatures for naturally conditioned spaces

de Dear (2004) has looked at both methods used in ASHRAE (2004) and found the PPD method to work well in HVAC controlled environments, although the adaptive temperature approach is more appropriate in naturally ventilated buildings like New Zealand houses. 


\section{Evidence of overheating in New Zealand houses}

New Zealand is unique in that it has monitored temperature and energy data for a representative sample of New Zealand. The dataset is from the HEEP project conducted at BRANZ Ltd (Isaacs et al 2006). This database allows the temperatures in homes to be analysed and influences determined. The sampling design means the database holds a statistically representative sample of New Zealand houses. The houses are located throughout the country and there is a full range of house and household types. Both fuel use and temperatures were surveyed for a year in 397 houses. HEEP also collected information on the house in a form of a house audit, floor plans and a comprehensive survey completed with the occupants, giving a comprehensive database of what New Zealand houses are like.

Full surveying of randomly selected houses in HEEP began in 1999 and was completed in 2005 . The newest houses in the sample were built in early 2004 . There have been some changes in house construction since; one key change has been a much higher installation of heat pumps in houses. Heat pumps are becoming common in new houses with close to $50 \%$ of new houses installing them at the time of construction (French 2008). Information was collected on the house, appliances, the hot water system and the occupants (Isaacs et al 2002). $\mathrm{RH}$, surface temperatures and occupant opinion of comfort were not measured in HEEP. A description of the temperature loggers used and how the loggers are affected by radiant heat is in Appendix A. 


\subsection{Temperatures during summer in New Zealand houses}

As discussed in Chapter 2 the temperature gives a good indication of the expected level of comfort - for this work $25^{\circ} \mathrm{C}$ or above is considered too hot. One percent of all houses spend over four hours a day during the summer above $25^{\circ} \mathrm{C}$. This $1 \%$ can be considered to be at uncomfortably high temperatures while over $25^{\circ} \mathrm{C}$. Figure 4 gives the percentages of time above, below and within the optimum temperature range as suggested by the World Health Organisation (WHO 2003). This includes all houses monitored in HEEP (Isaacs et al 2007) during the hours of $4 \mathrm{pm}$ to $6 \mathrm{pm}$ for the summer months (December, January and February). Although most houses can be considered comfortable, nearly one-third of all houses are uncomfortable during this time and this is higher for new houses.

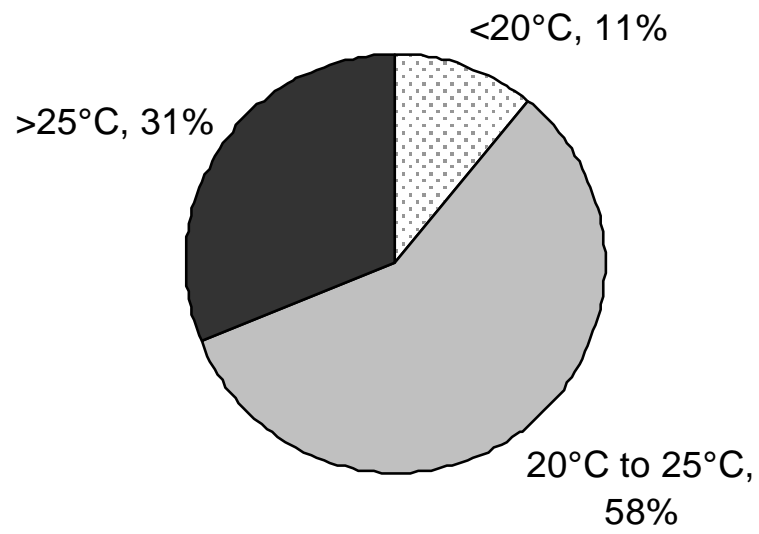

Figure 4: Average time in specified temperature ranges - summer $4 \mathrm{pm}$ to $6 \mathrm{pm}$

Temperatures in the monitored houses have been examined over the summer months in the living room. The temperatures have been examined during the day ( 9 am -5 $\mathrm{pm})$ and the evening $(5 \mathrm{pm}-11 \mathrm{pm})$. These times were chosen as the rooms are likely to be occupied. 
Figure 5 and Figure 6 give the mean living room evening and the daytime temperature distribution for the monitored houses. Temperatures during the evening range from $17.9^{\circ} \mathrm{C}$ to $27.3^{\circ} \mathrm{C}$ in the living room, with a mean of $23.1^{\circ} \mathrm{C}$. During the day they range from $16.3^{\circ} \mathrm{C}$ to $25.9^{\circ} \mathrm{C}$, with a mean of $21.8^{\circ} \mathrm{C}$. Table 1 gives the average minimums, maximums and means for different times of the day in the living rooms and bedrooms. Although the majority of houses can be considered comfortable most of the time, there are a significant number of houses overheating for a short period each day as shown in Figure 4 .

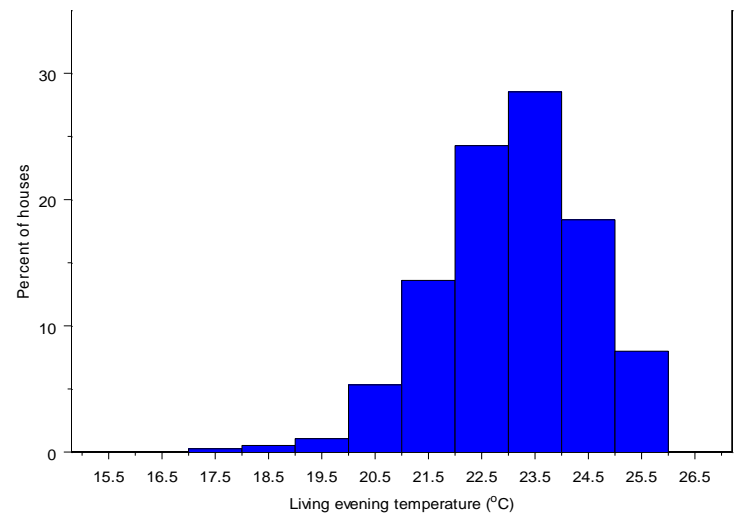

Figure 5: Living room evening summer temperature

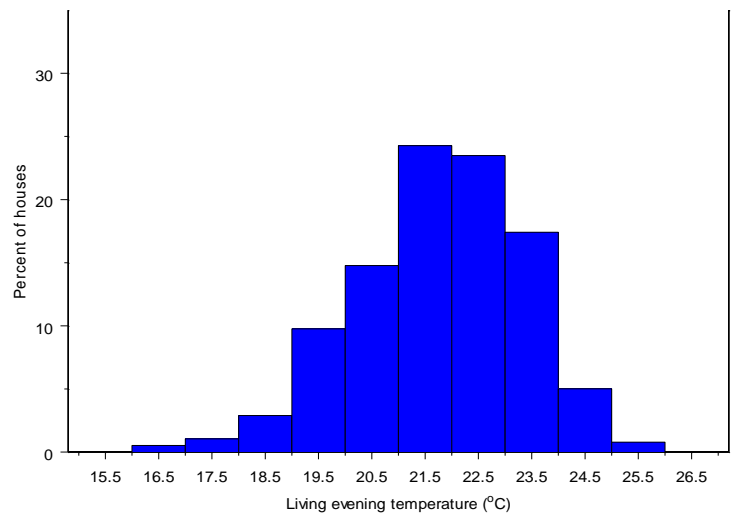

Figure 6: Mean living room daytime temperatures

Summer bedroom temperatures are similar to the living room temperatures (Table 1). Analysis of the HEEP houses has found New Zealand houses have randomly oriented windows. On average about one-quarter of the total glazing is in each of the four compass directions. This may explain the small temperature difference between living rooms and bedrooms in summer, when little or no heating is applied, as neither can be guaranteed to benefit from the sun. It is therefore likely the bedrooms, and the rest of the house, are uncomfortably warm if the living room is. 


\begin{tabular}{|c|ccccc|cccccc|}
\hline & \multicolumn{5}{|c|}{ Living room $\left({ }^{\circ} \mathrm{C}\right)$} & \multicolumn{5}{c|}{ Bedroom $\left({ }^{\circ} \mathrm{C}\right)$} \\
& & & & & 24 & & & & \\
& Morning & Evening & Night & Day & $\mathrm{hr}$ & Morning & Evening & Night & Day & $\mathrm{hr}$ \\
Average & 14.2 & 17.9 & 15.2 & 17.9 & 16.4 & 14.3 & 17.4 & 15.3 & 15.9 & 16.1 \\
minimum & & & & & & & & & & & \\
Average & 24.2 & 27.3 & 25.1 & 27.3 & 25.9 & 23.3 & 27.8 & 23.3 & 25.8 & 26.5 \\
maximum & & & & & & & & & & \\
Mean & 19.2 & 23.1 & 20.3 & 23.1 & 21.5 & 19.1 & 22.6 & 19.1 & 21.2 & 21.1 \\
\hline
\end{tabular}

Table 1: Living room and bedroom temperatures

\subsection{Maximum temperatures}

Figure 7 shows the maximum temperatures reached in the monitored houses. Almost all houses are above $25^{\circ} \mathrm{C}$ with some as high as $38^{\circ} \mathrm{C}$, a very uncomfortable temperature. 


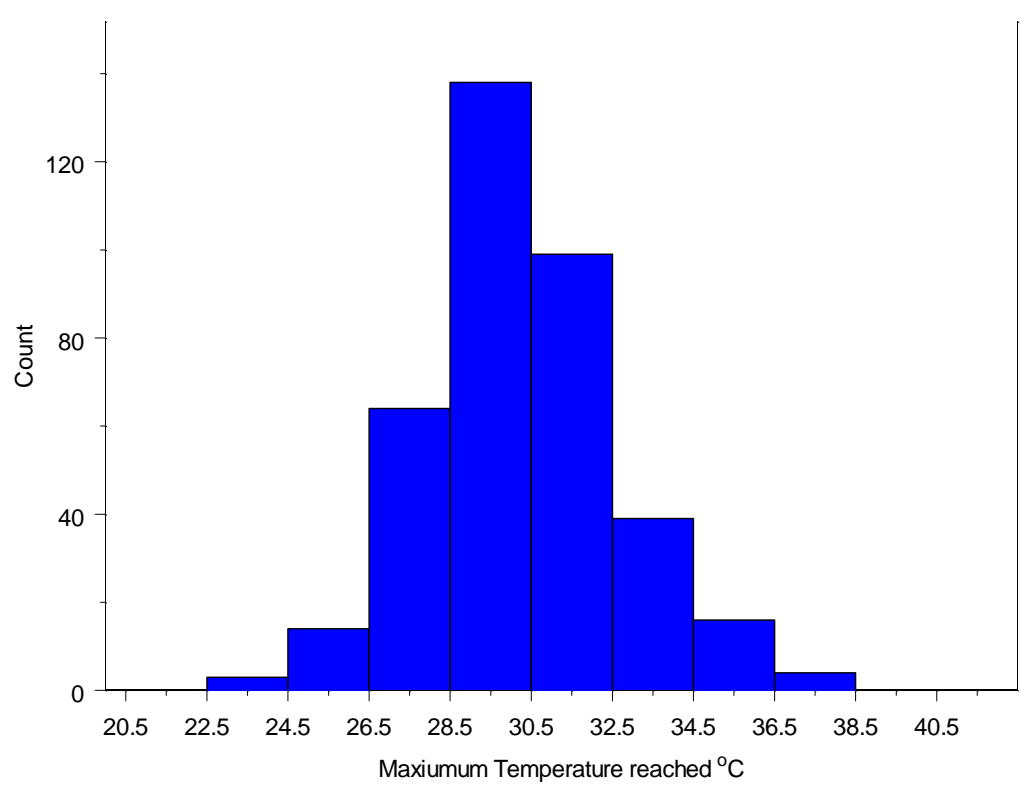

Figure 7: Maximum temperatures reached in New Zealand houses

On average, the maximum temperature in the living room is reached at $5.40 \mathrm{pm}$, although there is regional variation from $5 \mathrm{pm}$ in the north to $6.40 \mathrm{pm}$ in the south. The time of day the maximum temperature is reached is significant as occupants are likely to be home at this time. Electricity loads are at their highest at this time of day, due to occupants arriving home and switching on appliances. It is a time of day when the electricity network is already strained and the potential extra load from active cooling is large.

\subsection{Influences on summer temperature}

To understand how to prevent overheating it is necessary to understand the influences on summer temperatures. The main drivers of summer living room daytime temperature have been found to be the climate and the age of the house (French et al 2006). Given the lack of cooling and heating during summer, this is not surprising. Just $4 \%$ of the HEEP houses were found to be capable of cooling through heat pumps working in reverse. A small number of houses (3\%) heat throughout the whole year; 
these houses are mainly in the cooler southern areas of New Zealand. Since the monitoring study was completed the amount of cooling and capacity for cooling has changed quickly. Nearly $20 \%$ of households can now cool with $60 \%$ of these choosing to do so (French 2008).

Linear modelling has found that house age and external mean temperature explain $60 \%$ to $69 \%$ of the variation, depending on the time of day (e.g. morning, day, evening and night), and explain $74 \%$ of the variation for a 24 hour mean temperature ( $p$-value = $0)$. The house age alone explains $14 \%$ of the variation in daytime living room temperatures. New houses are warmer and at greater risk of overheating.

The influence of climate can be seen in Figure 8. The external temperature for the region is shown as a solid black square. The mean living room daytime temperatures are warmer in the warmer northern locations of New Zealand.

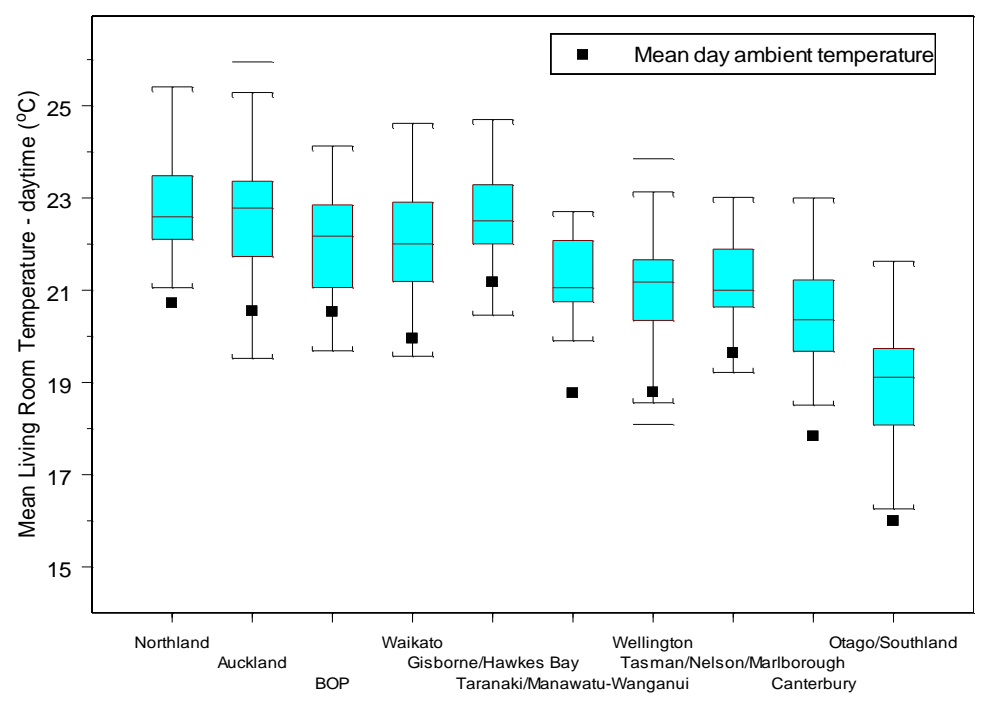

Figure 8: Mean summer living room daytime temperatures by Regional Council 
With few HEEP houses being cooled or heated, the indoor temperature relates strongly to the outside temperature - the warmer the climate, the warmer the house. Data analysis shows that for each average external temperature increase ${ }^{1}$ of $1^{\circ} \mathrm{C}$, the mean living room temperature increases by $0.8^{\circ} \mathrm{C}$. Through climate change a $3^{\circ} \mathrm{C}$ temperature rise is possible (see Chapter 4.2), and we can expect on average our houses to be $2.4^{\circ} \mathrm{C}$ warmer in summer. This would make the mean daytime summer living room temperature over $24^{\circ} \mathrm{C}$, close to the upper limit for comfort of $25^{\circ} \mathrm{C}$.

The mean summer living room temperatures show a trend of increasing by $0.25^{\circ} \mathrm{C}$ each decade the house was built. This gives a difference of $2.5^{\circ} \mathrm{C}$ between houses built at the beginning and end of the $20^{\text {th }}$ century. Figure 9 gives a box plot of the house age against the mean day temperature. Over half of the oldest houses (pre-1910) in the sample have a mean temperature of below $20^{\circ} \mathrm{C}$. Houses built from 1990 onwards all have a mean daytime living room summer temperature of above $20^{\circ} \mathrm{C}$, with the average temperature in this group close to $23^{\circ} \mathrm{C}$ and extreme means above $25^{\circ} \mathrm{C}$.

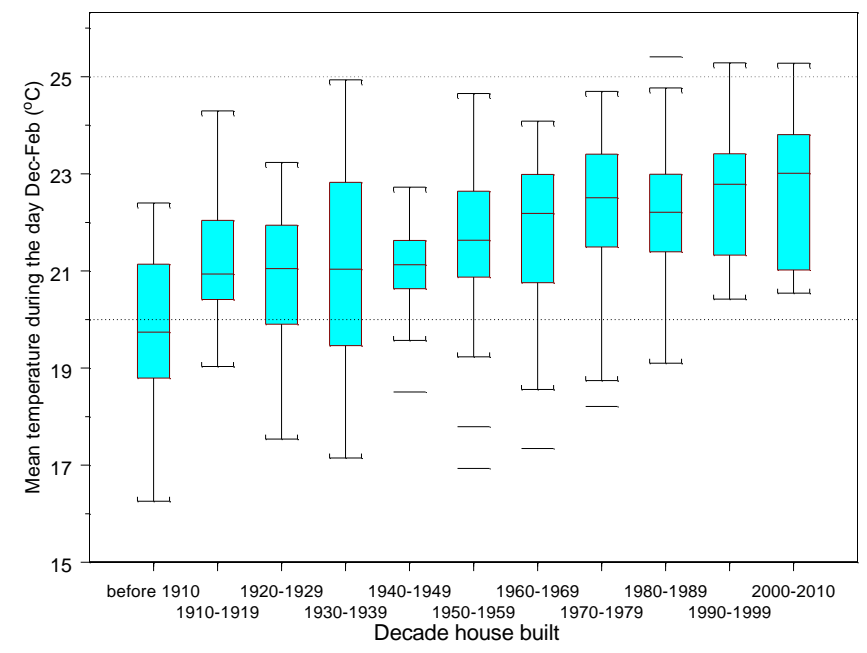

${ }^{1}$ Average external temperatures were calculated using NIWA CLIDB temperatures for the year the house was monitored. 


\section{Figure 9: Summer temperatures by house age}

The New Zealand Building Code (NZBC) uses climatic data to separate New Zealand into three climate zones for house insulation regulations. These three zones have been used to separate the HEEP sample to look at the effects of climate. Climate zone 1 is the warmest (includes Auckland, Northland and the Coromandel), and zone 3 is the coolest (includes the South Island and the central plateau in the North Island), with zone 2 comprising of the rest of the North Island see Figure 10 and Figure 11. The black squares are locations where monitoring was completed (Isaacs et al 2006).

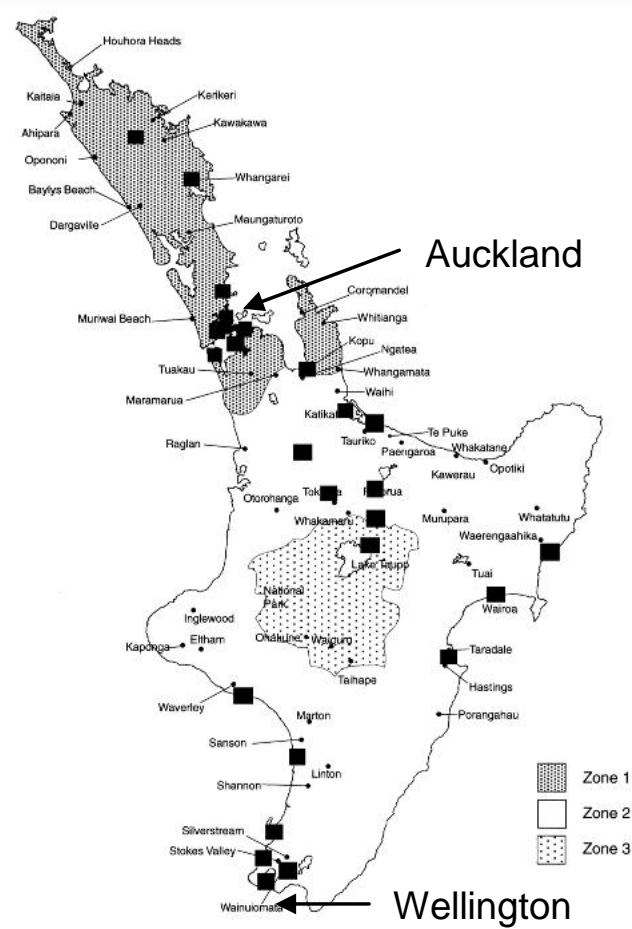

Figure 10: North Island climate zones and HEEP locations ${ }^{2}$

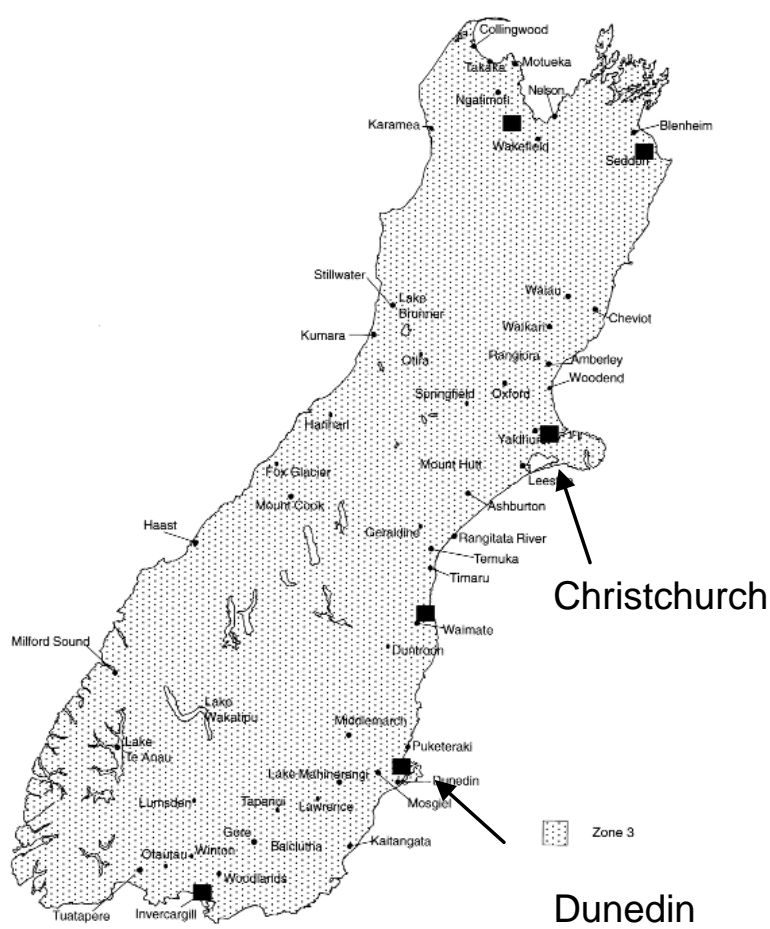

Figure 11: South Island climate zones and HEEP locations ${ }^{3}$

2 Standards New Zealand 2003.

3 Standards New Zealand 2003. 
Table 2 shows an increase in mean temperature between the pre-1950s and post1950s houses of between $0.7^{\circ} \mathrm{C}$ and $1.2^{\circ} \mathrm{C}$ depending on the climate zone. The colder the climate zone the greater the temperature difference between pre and post-1950s houses. It has been found that the largest temperature differences are between pre and post-1950s houses. Where appropriate for this work the monitored houses have therefore been divided into pre and post-1950 to examine the house age influence.

\begin{tabular}{|lc|cc|cc|c|}
\hline \multirow{2}{*}{ House age } & \multirow{2}{*}{ Climate zone } & \multicolumn{2}{|c|}{ Living room } & \multicolumn{2}{|c|}{ External } & \multirow{2}{*}{ House count } \\
& & Mean $\left({ }^{\circ} \mathbf{C}\right)$ & SE $\left({ }^{\circ} \mathbf{C}\right)$ & Mean $\left({ }^{\circ} \mathbf{C}\right)$ & SE $\left({ }^{\circ} \mathbf{C}\right)$ & \\
\hline Pre-1950 & 1 & 23.2 & 0.2 & 19.0 & 0.1 & 29 \\
Post-1950 & 1 & 23.9 & 0.1 & 19.1 & 0.1 & 111 \\
\hline Pre-1950 & 2 & 22.5 & 0.3 & 18.3 & 0.1 & 27 \\
Post-1950 & 2 & 23.5 & 0.1 & 18.4 & 0.1 & 104 \\
\hline Pre-1950 & 3 & 21.1 & 0.3 & 15.7 & 0.2 & 24 \\
Post-1950 & 3 & 22.3 & 0.2 & 16.0 & 0.1 & 60 \\
\hline
\end{tabular}

Table 2: Living room and external evening temperatures by house age

Excluded N/As- not all houses were able to be classified for age

External temperatures differ due to different houses being monitored each year

Table 3 gives the percent of average hours in three specified temperature ranges for pre and post-1950s houses in the three climate zones. For all three climate zones it can be seen there is a greater amount of time being spent above $25^{\circ} \mathrm{C}$ for the post1950 houses, and less time being spent under $20^{\circ} \mathrm{C}$. In climate zone 3 the amount of time over $25^{\circ} \mathrm{C}$ has more than doubled ( $8 \%$ to $17 \%$ ) between pre and post-1950. 


\begin{tabular}{|c|c|c|c|c|c|c|c|c|}
\hline $\begin{array}{c}\text { House } \\
\text { age }\end{array}$ & $\begin{array}{c}\text { Climate } \\
\text { zone }\end{array}$ & $\begin{array}{r}<20^{\circ} \mathrm{C} \\
(\%)\end{array}$ & SE & $\begin{array}{c}20-25^{\circ} \mathrm{C} \\
(\%)\end{array}$ & SE & $>25^{\circ} \mathrm{C}(\%)$ & SE & $\begin{array}{l}\text { House } \\
\text { count }\end{array}$ \\
\hline Pre-1950 & 1 & 8 & 1.5 & 70 & 3.4 & 22 & 3.7 & 29 \\
\hline Post-1950 & 1 & 4 & 0.5 & 65 & 1.5 & 31 & 1.6 & 111 \\
\hline Pre-1950 & 2 & 18 & 3.4 & 65 & 2.9 & 17 & 2.9 & 22 \\
\hline Post-1950 & 2 & 9 & 0.9 & 62 & 1.4 & 29 & 1.7 & 101 \\
\hline Pre-1950 & 3 & 34 & 4.0 & 58 & 3.4 & 8 & 1.6 & 24 \\
\hline Post-1950 & 3 & 19 & 2.1 & 65 & 1.7 & 17 & 1.8 & 59 \\
\hline
\end{tabular}

Table 3: Summer evening living room temperatures

Excluded N/As - not all houses were able to be classified for age

Table 4 gives the mean daily maximum and minimum temperatures by house age and climate zone for summer. The post-1950 houses have higher or the same maximums and minimums in all climate zones.

\begin{tabular}{|c|c|c|c|c|c|c|}
\hline \multirow{2}{*}{ House age } & \multirow{2}{*}{$\begin{array}{c}\text { Climate } \\
\text { zone }\end{array}$} & \multicolumn{2}{|c|}{$\operatorname{Temp}\left({ }^{\circ} \mathbf{C}\right)$} & \multirow{2}{*}{$\begin{array}{l}\text { Count of } \\
\text { Houses }\end{array}$} & \multicolumn{2}{|c|}{$\operatorname{Temp}\left({ }^{\circ} \mathrm{C}\right)$} \\
\hline & & Max LR & Min LR & & Max Ext & Min Ext \\
\hline Pre-1950 & 1 & 24.3 & 19.6 & 29 & 22.0 & 15.2 \\
\hline Post-1950 & 1 & 25.3 & 19.6 & 111 & 22.2 & 15.4 \\
\hline Pre-1950 & 2 & 23.2 & 18.5 & 22 & 22.1 & 12.3 \\
\hline Post-1950 & 2 & 24.8 & 19.0 & 101 & 22.2 & 12.9 \\
\hline Pre-1950 & 3 & 22.4 & 16.7 & 24 & 19.5 & 10.6 \\
\hline Post-1950 & 3 & 23.5 & 17.8 & 59 & 19.7 & 11.2 \\
\hline
\end{tabular}

Table 4: Daily mean maximum and minimum temperatures over summer

Excluded N/As

LR - Living room temperature

Ext - External temperature 


\subsection{Temperature measurement in the monitored houses}

The temperatures measured were air temperatures at two heights in the living room, and one height in the main bedroom (Isaacs et al 2006). The average of these two temperatures gives a temperature at approximately the head height for a seated person. Temperatures were recorded on a 10 minute basis. Sensors were placed out of direct sunlight and away from heating sources. The data was downloaded monthly and checked thoroughly to remove any errors. Surveying of each house was carried out for approximately one year. Temperature measurements were carried out with two types of loggers (see Appendix A).

Overall the quality of temperature data in the database is high Table 5 shows the two different loggers used for logging the temperatures inside the houses and the data that is 'missing'. Data can be missing for several reasons such as: the logger was incorrectly set; the battery in the logger went flat; data collected was not representative of the room (e.g. the logger was hit by direct sunlight); and a few files were lost with computer problems. Tiny-tags have more missing data than the BRANZ temperature loggers (BTL) at 12\%, however less monitoring was done by Tiny-tags. From the 732 BTLs monitoring the living room, $8 \%$ of the data was missing.

\begin{tabular}{|c|cc|}
\hline & $\begin{array}{c}\text { Data missing } \\
(\%)\end{array}$ & $\begin{array}{c}\text { Number of circuits } \\
\text { monitored }\end{array}$ \\
\hline BRANZ temperatures loggers & 8 & 871 \\
Tiny-tag temperatures loggers & 12 & 312 \\
\hline
\end{tabular}

Table 5: Missing data - Tiny-tag and BRANZ temperature loggers

To ensure the room representative air temperature was measured the radiative heat to a temperature logger was minimised, by not placing the logger in the direct path of 
strong radiant sources. The loggers were placed where they were not exposed to moisture and kept out of reach of children and pets. It was not always possible to keep the loggers out of direct sunlight for the whole year. When the sun did hit the logger the temperature rose rapidly. This data was removed during the data cleaning.

External weather data was obtained from the National Institute of Water and Atmospheric Research's (NIWA) national climate database (CLIDB) (Penny 2003). 


\section{New Zealand's climate - is overheating expected?}

This section is designed to give an overview of the climate in New Zealand. The following overview shows the climate is mild and overheating should be preventable in most locations in New Zealand. New Zealand houses are known to heat for between three and eight months of the year (Isaacs 2006). In the past cooling has not been done (French et al 2007b).

New Zealand is a long and narrow country, approximately $1,600 \mathrm{~km}$ in length, with a land area of $270,000 \mathrm{~km}^{2}$, ranging from latitude $37^{\circ} \mathrm{S}$ to $46^{\circ} \mathrm{S}$ (Statistics New Zealand 2005). Most homes are in a coastal type climate, with the central areas of both islands more continental. The overview of the climate is given for the four locations shown on Figure 10 and Figure 11.

The summer months in New Zealand (a southern hemisphere country) are December, January and February. January and February are the warmest months of the year with approximately the same mean air temperature. July is typically the coldest month.

\subsection{Temperatures}

In Auckland (far north), the average summer ambient temperature is $19.3^{\circ} \mathrm{C}$ over 24 hours, while in Dunedin (far south) it is $15.2^{\circ} \mathrm{C}$ - a difference of $4.1^{\circ} \mathrm{C}$ degrees.

The annual range of monthly mean temperatures (difference between the mean temperature of the warmest and coldest months) is small. In the top of the North Island (Northland) and in western districts of both islands it is approximately $8^{\circ} \mathrm{C}$. For the remainder of the North Island and east coast districts of the South Island it is $9^{\circ} \mathrm{C}$ to 
$10^{\circ} \mathrm{C}$. Further inland in the South Island, the annual range can exceed $11^{\circ} \mathrm{C}$, reaching a maximum of $14^{\circ} \mathrm{C}$ in Central Otago (MetService 2006).

Table 6 gives the air temperatures for four cities spread throughout the country, for January (summer), July (winter) and the annual average.

\begin{tabular}{|c|cc|c|}
\hline Location & Jan $\left({ }^{\circ} \mathbf{C}\right)$ & Jul $\left({ }^{\circ} \mathbf{C}\right)$ & Annual $\left({ }^{\circ} \mathbf{C}\right)$ \\
\hline Auckland & 19.3 & 10.8 & 15.1 \\
Wellington & 16.9 & 8.8 & 12.8 \\
\hline Christchurch & 17.4 & 6.6 & 12.1 \\
Dunedin & 15.2 & 6.5 & 11.0 \\
\hline
\end{tabular}

Table 6: Mean air temperatures (NIWA 2007)

\subsubsection{Sun hours}

Table 7 gives the number of sun hours for January, July and annually, for four locations in New Zealand. This compares to 186-341 hours for January in Australia (Bureau of Meteorology 2008).

\begin{tabular}{|c|cc|c|}
\hline Location & Jan (hrs) & Jul (hrs) & Annual (hrs) \\
\hline Auckland & 229 & 140 & 2060 \\
Wellington & 246 & 117 & 2065 \\
\hline Christchurch & 230 & 124 & 2100 \\
Dunedin & 178 & 101 & 1585 \\
\hline
\end{tabular}

Table 7: New Zealand sun hours (NIWA 2007)

\subsubsection{Relative humidity}

Table 8 gives $\mathrm{RH}$ levels which are similar throughout New Zealand. Due to the warmer temperatures in northern New Zealand (Auckland area), this is the only area that 
regularly has conditions during summer that are uncomfortable, due to high $\mathrm{RH}$ and high temperature. This could however change quickly with climate change. If temperatures increase in Wellington, $\mathrm{RH}$ could become a significant issue for comfort.

\begin{tabular}{|c|ccc|}
\hline Location & Jan (\%) & Jul (\%) & Annual (\%) \\
\hline Auckland & 77.1 & 88.5 & 81.1 \\
Wellington & 80.3 & 86.3 & 82.9 \\
\hline Christchurch & 72.9 & 87.3 & 79.6 \\
Dunedin & 73.1 & 80.2 & 75.8 \\
\hline
\end{tabular}

Table 8: New Zealand's relative humidity (\%) (NIWA

2007)

Data is mean monthly values of 9 am $\mathrm{RH}$ for the 1971 -

2000 period for locations having at least five complete

years of data

\subsection{Climate change and New Zealand}

On average New Zealand can expect the following changes from climate change:

- Average temperatures increasing by $1^{\circ} \mathrm{C}$ by the 2030 s and $2-3^{\circ} \mathrm{C}$ by the 2080s

- Sea level rise - by 2100 a $30-50 \mathrm{~cm}$ rise is likely

- More rain in the west of the country and less in the east

- Westerly winds are likely to be more prevalent (Ministry for the Environment (2008).

These changes should be considered when building today, as these are the buildings that will be affected by climate change. 
The change of most concern for thermal comfort is the increase in temperatures. Many houses in New Zealand are over 100 years old, and ideally houses built today will still be lived in 100 years from now. 


\section{Description of New Zealand houses}

The following section describes New Zealand houses using both the HEEP database and literature. The database can be used for understanding the current housing stock, due to it holding information on a statistically representative sample of New Zealand houses (Isaacs et al 2006). The quarterly BRANZ Ltd materials survey (Page 2005 gives a description of the ongoing survey) is able to be used to understand current building practices from building consent information. It is important to understand how houses are built to therefore understand what features are changing and what is causing the increasing temperatures. The following analysis is from the representative HEEP database.

A typical house in New Zealand is timber framed with weatherboard or brick veneer cladding (75\% of HEEP sample), a timber (60\%) or concrete floor $(30 \%)$ and a long-run steel roof $(61 \%)$ or tiles $(22 \%)$. Houses are typically stand-alone with one level $(71 \%)$ or two levels $(26 \%)$. The concrete slab floor is normally covered with carpet $-66 \%$ of houses with slab floors have carpet throughout their living areas compared to $57 \%$ of houses with suspended timber.

Approximately 25,000 new houses are built each year, with the majority being in Auckland. Figure 12 shows the number of annual new dwellings from consents issues in the four regions with the highest number of consents issued. Auckland and Christchurch are two of the warmest areas in New Zealand where houses are at greatest risk of overheating and are also the areas of largest growth of new houses. 


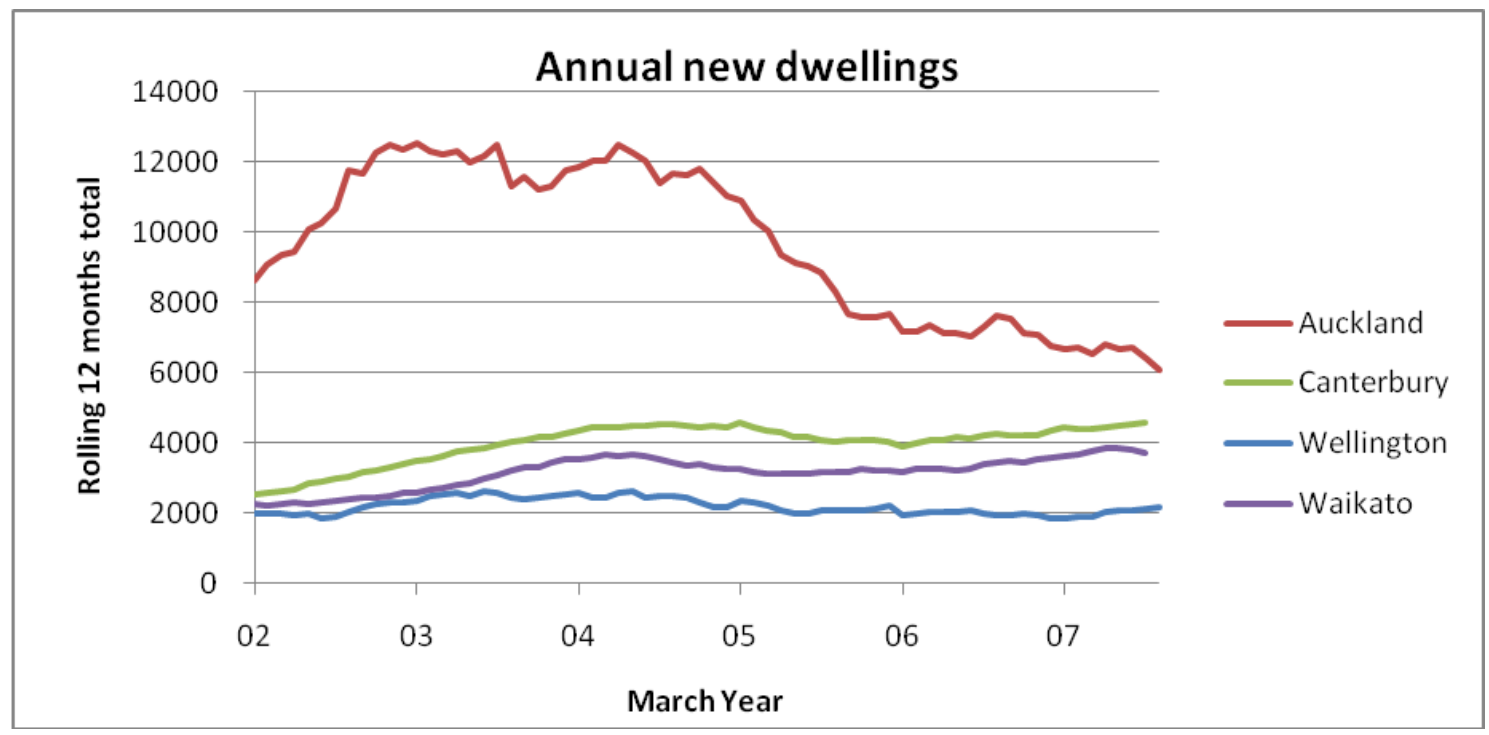

Figure 12: New dwelling consents 4

\subsection{New Zealand Building Code}

New Zealand houses have been required to have thermal insulation since 1 April 1978. These modest requirements were increased slightly for houses in the central North Island and all the South Island (Zone 3) in 1996. Figure 10 and Figure 11 show the North and South Island of New Zealand and the three climate zones. Table 9 sets out thermal resistance requirements for common combinations of roof, wall and floor (Isaacs 1993 and 1999). One of the main changes in the recent revision is single to double glazing in the schedule method of compliance - in warmer parts of New Zealand it is possible with good design and using another method of compliance that double glazing will not be required. Given these changes are happening at the completion of this work, and after the monitoring of HEEP, none of the houses in the sample are built to the new requirements. It is important to recognise these changes in the modelling component of this work to see if insulation levels have an effect.

4 Ian Page (BRANZ Economics Manager) compiled information from building consents issued (27 February 2008). 


\begin{tabular}{|c|c|c|c|c|c|c|}
\hline \multirow{2}{*}{$\begin{array}{c}\text { Year } \\
\text { commenced }\end{array}$} & \multirow{2}{*}{ Standard } & \multirow{2}{*}{ Coverage } & \multicolumn{4}{|c|}{ R-values $\left(\mathbf{m}^{2}{ }^{\circ}\right.$ C/W) } \\
\cline { 4 - 7 } & & Windows & Ceiling & Wall & Floor \\
\hline 1978 & NZS 4218P:1978 & New Zealand & 0.15 & 1.9 & 1.5 & 0.9 \\
\hline 1996 & NZS 4218:1996 & Zones 1\&2 & 0.15 & 1.9 & 1.5 & 1.3 \\
& & Zone 3 & 0.15 & 2.5 & 1.9 & 1.3 \\
\hline 2007 & NZS 4218:2007 & Zone 3 & 0.26 & 3.3 & 2.0 & 1.3 \\
2008 & & Zone 2 & 0.26 & 2.9 & 1.9 & 1.3 \\
2009 & & Zone 1 & 0.26 & 2.9 & 1.9 & 1.3 \\
\hline
\end{tabular}

Table 9: Building Code thermal performance requirements 1978 to current

The thermal insulation requirements apply only to new houses. Older houses are not required to upgrade to the current standard, unless being modified.

\subsection{House age}

New Zealand is a young country, with most houses being built from the 1950s onwards (Figure 13). The oldest houses in HEEP were built in the 1860 s but there are few houses of this age. The most number of consents in one year was 40,000 , in the mid1970s. 


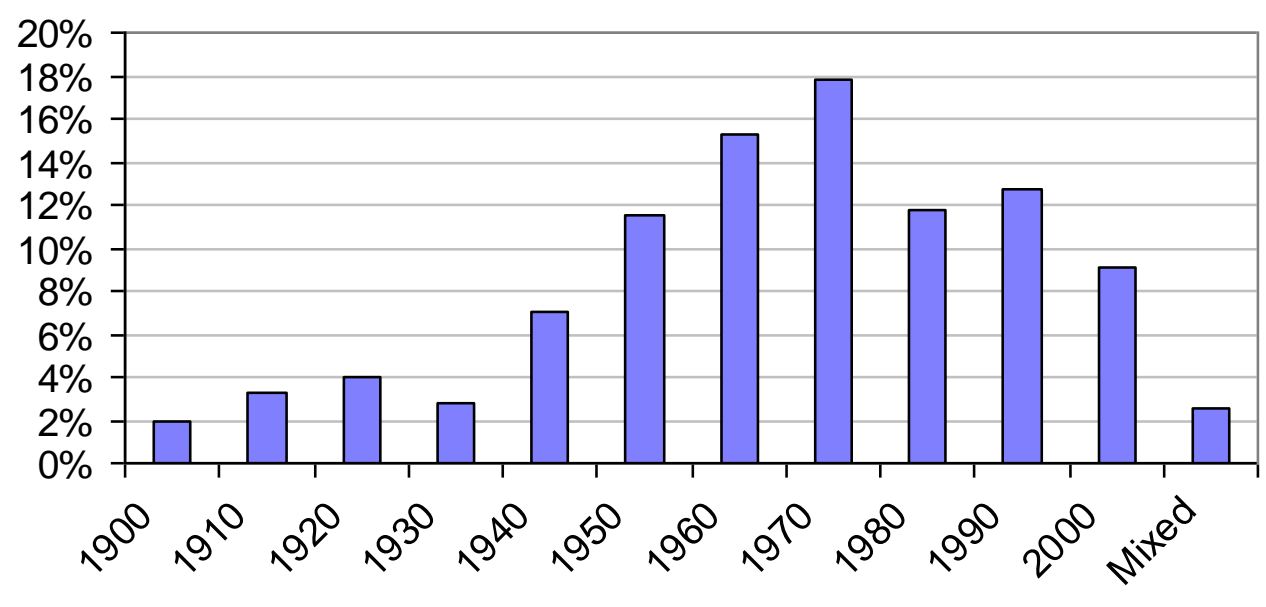

Figure 13: Counts of house by age (Quotable Value 2007)

\subsection{How are houses changing overtime?}

The information from the HEEP database and the literature, allows the changes in design and construction over time to be examined. The changes over the years are significant for this research to determine what features of new houses are causing the increasing summer temperatures. Once the features are known their influence on indoor temperature can be examined. As shown earlier the examination of temperatures has found the largest differences occur between pre and post-1950 houses (Chapter 3.3). Where appropriate the database has therefore been examined to find differences in construction and design by pre and post-1950 houses.

Below are some of the design and construction features that were found to change over the years:

- Increasing glazing areas - increased solar gains

- Less solar shading from eaves - increased solar gains

- Increased insulation - trapping heat inside

- Increased use of concrete slab floors - increasing thermal mass

- Increased use of sheet materials - increasing airtightness 
- Aluminium windows - increased airtightness

- Attached garages - lower heat losses through wall.

Figure 14, Figure 15 and Figure 16 show three typical New Zealand houses from three different time periods. Some of the changes mentioned above can be seen in the photos.

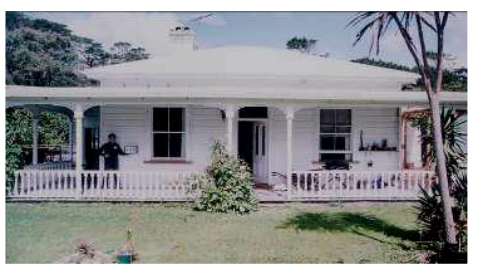

Figure 14: Early 1900s

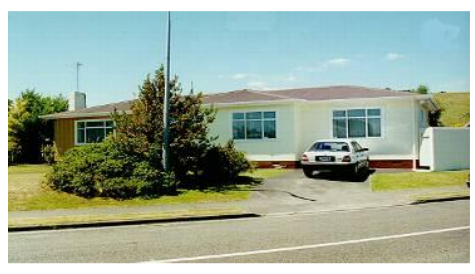

Figure 15: Mid-1900s

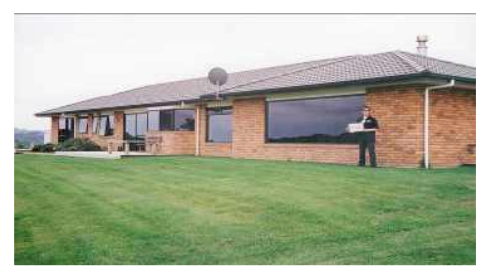

Figure 16: Post-2000 house house

\subsubsection{House size}

Newer houses are increasing in size - the average New Zealand house being built today is $240 \mathrm{~m}^{2}$ (Page 2005 is a descriptive paper on the ongoing survey). In the HEEP sample the average size is $121 \mathrm{~m}^{2}$, the largest $315 \mathrm{~m}^{2}$ and the smallest $51 \mathrm{~m}^{2}$ (Isaacs et al 2006).

\subsubsection{Glazing}

Newer houses have been found to have larger glazing areas. Table 10 gives the solar glazing area (east, west and north glazing) as a percentage of solar wall area (east, west and north walls). The larger the glazing area means not only more solar gains during the day heating the space, but more losses at night. For all three climate zones 
the post-1950 houses have a larger percentage of glazing area. The climate zones and pre and post-1950 houses differences are significant ( $p$-value: 0.045$)$.

\begin{tabular}{|lcccc|}
\hline House age & Climate zone & Solar glazing / solar wall area (\%) & SE & Count of houses \\
\hline Pre-1950 & 1 & 23.9 & 2.7 & 30 \\
Post-1950 & 1 & 27.4 & 1.4 & 112 \\
\hline Pre-1950 & 2 & 24.1 & 2.0 & 27 \\
Post-1950 & 2 & 28.3 & 1.3 & 105 \\
\hline Pre-1950 & 3 & 27.0 & 3.8 & 24 \\
Post-1950 & 3 & 30.5 & 1.8 & 58 \\
\hline
\end{tabular}

Table 10: Solar glazing and house age - HEEP

Excluded N/As

Passive design for living room orientation can be examined in the database. Table 11 gives the living room orientation by house age. North, north-east and north-west are the most popular orientation for both pre and post-1950 houses. Living rooms with northern orientations have increased in the post-1950 houses, with a reduction in south, south-east and south-west facing living rooms. West and east have stayed similar over time. This is suggesting pre-1950 houses have living rooms facing the street, but after that around $60 \%$ of houses are sensibly oriented to the sun, increasing the useful solar gains entering the house and possibly the temperature. 


\begin{tabular}{|c|cc|}
\hline Living room orientation & Pre-1950 & Post-1950 \\
\hline N,NE,NW & $47 \%$ & $59 \%$ \\
S,SE,SW & $31 \%$ & $22 \%$ \\
W & $12 \%$ & $13 \%$ \\
E & $9 \%$ & $6 \%$ \\
\hline Count of houses & 74 & 266 \\
\hline
\end{tabular}

Table 11: Living room orientation - HEEP

Houses with two living rooms in different directions have been removed - therefore the percentages do not add to 100

The database holds information on glazing type, window area, frame type and orientation. Unfortunately information on the opening area of the window was not recorded. The opening area and location of the windows that open affect the amount of ventilation possible in the house. It was not possible to determine from the available information if the opening area is changing over time.

Most houses in the sample and in New Zealand have single glazing; only recently has double glazing been required by the NZBC (see Table 9).

Literature research supports the database. Pre-1900 houses (Figure 17) have small windows and the buildings are very symmetrical in design (Shaw 1997). Lincoln College (1860) shows pre-1900 houses with small windows and large opening areas. Often the houses are built to face the street, with little consideration given to how the sun will affect the building. There are often few windows down the sides of the house. 
The larger two-storey houses of this period often have double-hung windows, with half of the window opening, but the proportion of window-to-wall area is still low.

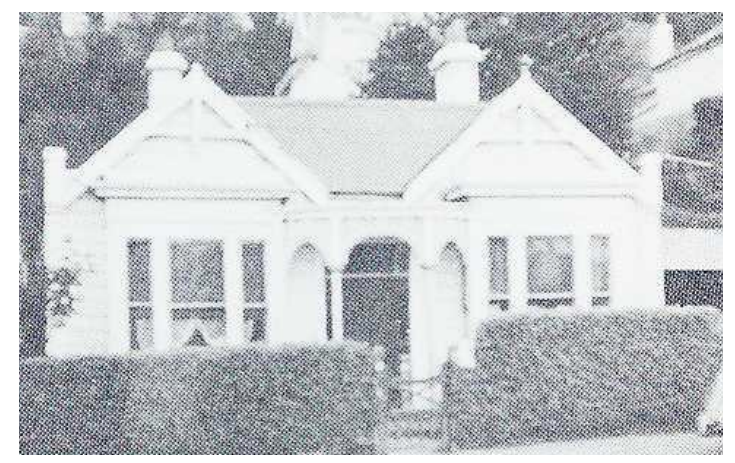

Figure 17: Pre-1900 house (Lincoln College 1975)

Fowler and van de Voort (1984) critique the many houses where the proportion of window-to-wall is not considered. They go on to point out the primary function of the house is for sheltering and the large areas of windows has lessened this primary function.

Shaw (1997) reports from the 1950s onwards there are larger glazing areas, often floor-to-ceiling and wall-to-wall and not always able to be opened (Figure 18 and Figure 19). Lincoln College report (1975) after the 1950s there was a wider range of house styles being built. Often with larger windows and reduced eave size. There were however still many houses built along the standard lines. The 1970s are reported as being an adventurous period with more money being spent on houses. The houses were bigger, with larger and more windows.

It can be concluded the amount of glazing in New Zealand houses is increasing. Reasons for this include architectural trends, technological advancements and 
increased money spent on houses. Glazing affects the amount of solar gains entering the house, therefore influencing the temperature.

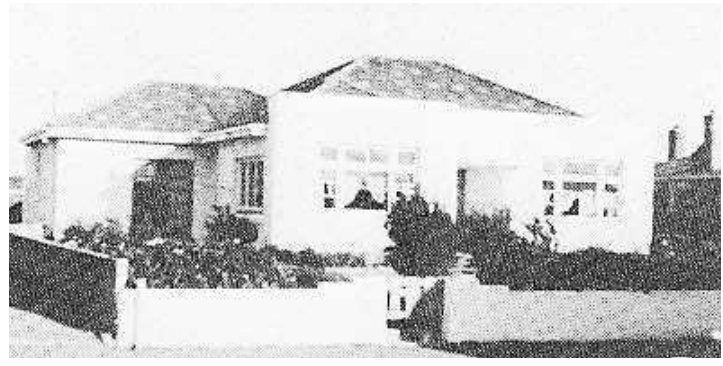

Figure 18: 1950s house (Lincoln College 1975)

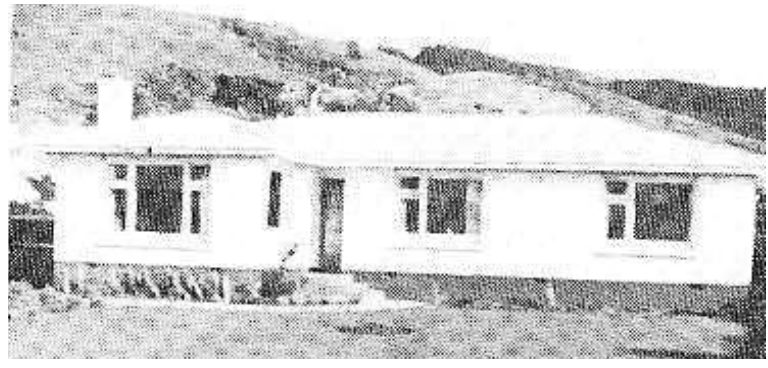

Figure 19: 1950s house (Lincoln College 1975)

\subsubsection{Shading/eaves}

External shading can be done through eaves and verandas and movable shading. It is difficult to find information on external shading in New Zealand houses. The eave size was not measured in HEEP. However through analysis of photographs newer houses were found to have smaller eaves, with some new houses having no eaves.

Many early colonial houses are seen to have a large veranda (Fowler and van de Voort 1984). Figure 20 shows an early colonial house known as Waitangi House which has a veranda that is a feature of most houses of this time. 


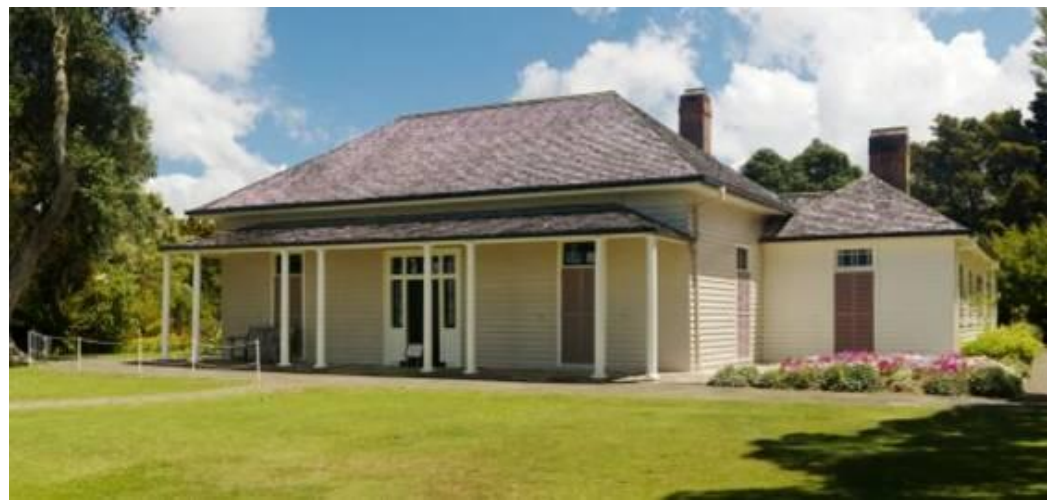

Figure 20: Early colonial house - Waitangi ${ }^{5}$

As reported earlier, houses built after the 1950s had a wider range of styles. This is when literature first noted that eave size was decreasing and verandas were becoming rare (Shaw 1997, Lincoln College 1975).

Figure 21 and Figure 22 show a modern architecturally designed home built in 2005. This house has shading on some windows, however it is limited.

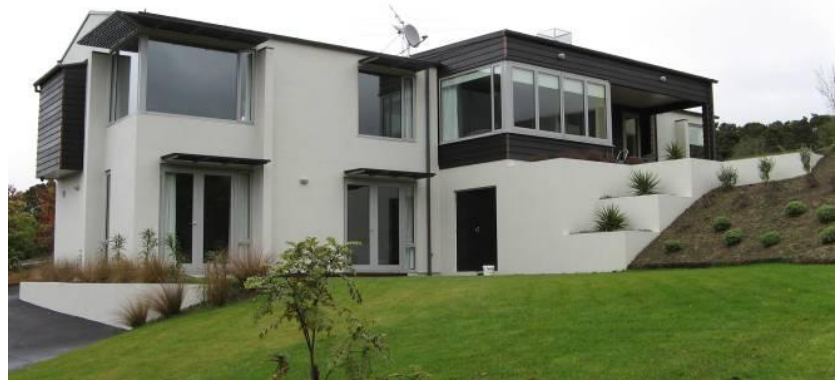

Figure 21: Modern New Zealand house built in $2005^{6}$

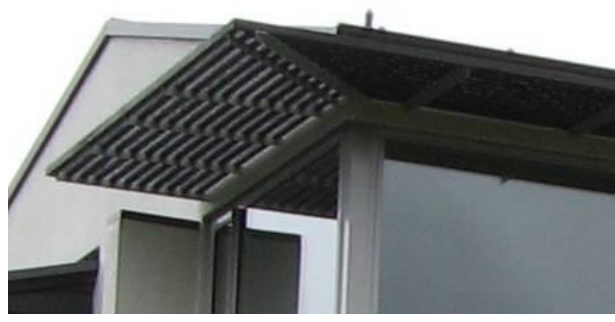

Figure 22: Close up of external shading ${ }^{7}$

5 http://en.wikipedia.org/wiki/Waitangi, Northland accessed 21 March 2008.

6 Photo taken by Lisa French October 2006.

7 Photo taken by Lisa French October 2006. 
Although there are no databases of eave sizes or verandas to conclude they are decreasing in new houses, both the literature and photographs examined in the database show less eaves and verandas in newer houses. External shading through eaves affects the amount of solar gains entering the house, and therefore the internal temperature.

\subsubsection{Insulation levels}

Houses from 1978 onwards were required to have insulation installed at construction (see Table 9). Pre-1978 houses are not required to have insulation, but many do have insulation installed, often only in the ceiling and patchy and/or of poor quality. The 2005 New Zealand 'House Condition Survey' performed by BRANZ (Clark et al 2005) found $60 \%$ of pre-1978 houses have ceiling insulation. Very few pre-1978 houses have wall insulation - generally only where there have been additions or extensive renovations. Under-floor insulation is found in a small number of houses where there was access, but often it is not throughout the house.

\subsubsection{Thermal mass}

Few New Zealand houses are built of solid construction. Only two houses out of 397 in the HEEP sample could be considered high mass with solid mass walls. The construction of floors has changed, with concrete slab becoming more common. Just $12 \%$ of pre-1950 houses have a slab, increasing to $40 \%$ for post -1950 and $65 \%$ for post-1978 (French et al 2007b). Sixty-six percent of concrete floors are covered with carpet. Concrete floors also increase the airtightness of the house.

\subsubsection{Sheet materials}

The materials used in the construction of houses are changing with time and this is influencing the airtightness of the house. Due to sheet materials being used, the 
houses are becoming increasingly airtight. Concrete slab floors are more common now than timber flooring (French et al 2007b), and when timber flooring is used plywood or particle board is standard rather than floor boards. Aluminium windows are standard in new houses and have been since the late 1970s, with most older houses still having the original timber-framed windows. Timber frames generally change size/shape slightly with age, resulting in a window that is not as airtight as a tightly-fitting aluminium window.

The changes to concrete floors, sheet materials and aluminium windows are all leading to increased airtightness of houses, lowering the background infiltration. This is discussed further in the next section.

\subsubsection{Airtightness and infiltration}

An airtight house means less heat losses - this is great in winter but could be contributing to higher temperatures in summer. Ideally houses should have the ability to control ventilation when needed e.g. opening windows that are not a security risk or allowing unwanted noise inside.

Airtightness was not able to be measured in HEEP houses, due to the expense in both time and money. Occupants were therefore asked their opinion on the airtightness of the house. As there are many influences on infiltration, it was not possible to estimate the air change rate for each house.

Previous work by Bassett (1992) found house age affects the airtightness. Figure 23 shows newer houses are more airtight. The ac/h given are not representative of air changes through natural ventilation, but are used to make comparisons between 
buildings, and typically these air leakage rates are around 20 times the leakage rate driven by normal wind and stack pressures.

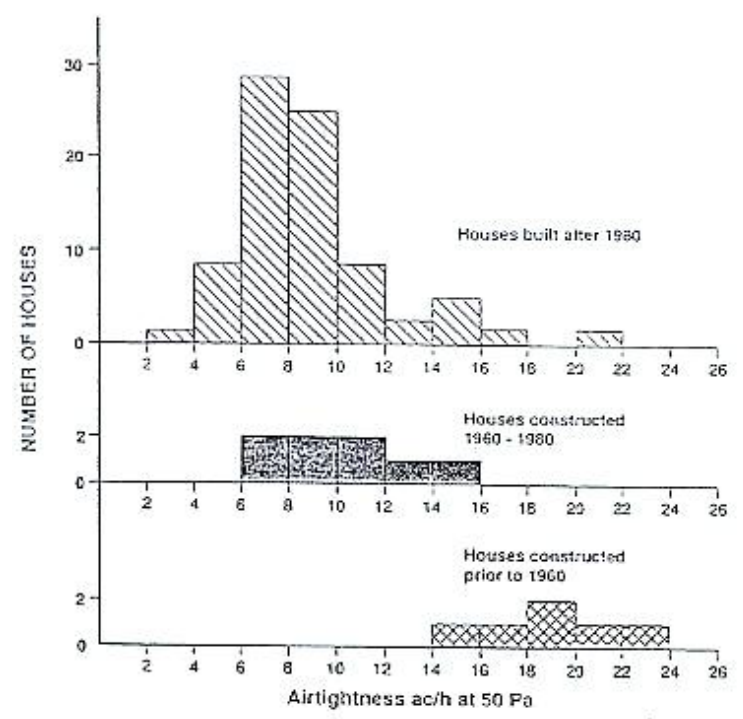

Figure 23: Histogram of air change rates at $50 \mathrm{~Pa}$ for 40 New Zealand houses (Bassett 1992)

An airtight house limits the houses to remove heat build-up in the house.

\subsubsection{Attached garages}

Attached garages with internal access are fairly standard in new houses. Before the 1950s this was very rare (Lincoln College 1975). Garages are not required to be insulated if they are not conditioned. They therefore can become very warm during summer, due to the lightweight construction and heat generated from vehicles. In many cases it may be possible for the heat in the garage to flow into the rest of the house.

Attached garages have the ability to increase the internal gains, affecting the indoor temperature. 


\section{Features contributing to overheating - literature review}

To understand what changes are happening in new houses that could be causing temperatures to increase in summer, a literature review has been undertaken. This review has examined features of design and construction, which are recognised as affecting the internal temperatures. The review covers both features that prevent overheating and cause the temperature to increase. By knowing what features prevent overheating, the opposite in many cases can be examined to determine what features are causing increasing temperatures.

The literature review covers both New Zealand and overseas literature. Generally New Zealand literature focuses on heating and staying warm in winter, however more recently cooling is being considered.

Several features were common throughout the literature. These features have been expanded on further. They are:

- The level of ventilation

- The airtightness of the house

- The amount and orientation of glazing

- External shading

- Thermal mass

- Site selection

- The level of insulation

- The amount of internal gains. 
At the end of each section the method used to examine the feature through modelling has been given.

\subsection{Glazing}

Glazing allows solar gains to enter the house, warming the indoor air, and allowing daylight into the interior. Glazing is therefore very important in both summer and winter. The orientation and the amount and type of glazing directly affects the amount of solar gains entering the house. During winter solar gains are beneficial, but glazing also increases heat losses. So increasing the amount of glazing does not always result in warmer temperatures. When the house is already warm, having solar gains could cause the house to overheat. Chiras (2002) suggests it is necessary to reduce or eliminate solar gains to allow passive cooling. He says window placement should be the first consideration.

Methods suggested by BRANZ (2005) for reducing solar gains in New Zealand houses include:

- Reducing north-facing windows

- Shading north-west windows by eaves or overhangs, trees or shrubs

- Using reflective glazing

- Fitting internal reflective blinds

- Using light-coloured roofs and walls to reflect solar radiation

- Using double glazing.

The height of the sun needs to be considered. Glazing facing west (where the sun sets) can lead to overheating in the evening, as the sun is low and generally not shaded by house eaves (Donn and Thomas 2001). Skylights will allow solar gains into 
the interior during summer as the sun is high, and skylights are very difficult to shade. It does however make them very effective for daylighting (Donn and Thomas 2001).

To examine glazing the area of glazing has been altered in the models, by doubling and halving the width of the original window.

\subsection{Shading/eaves}

As mentioned previously solar gains increase the internal temperature, therefore appropriate shading of the glazing is considered important to prevent overheating in summer. External shading is considered to be most effective, as this prevents the heat entering the interior (Chiras 2002). Interior shading will cause a build-up of heat between the shading device and window and much of this heat will eventually enter the room (Chiras 2002). Lane (1986) suggests sun control devices are necessary during summer, to decrease the cooling load if there is sufficient glazing for passive heating during winter. Pearson (1998) suggests some options for external shading including:

- Wider roof eaves

- Awnings

- Shutters

- Screens

- Verandas

- Blinds and low-emissivity glass

- Shading the whole structure with trees, shrubs, creepers and earth shelter.

Different levels of external shading were tested in this work by using different sized eaves. 


\subsection{Insulation}

Insulation is one area where there is conflicting information. Insulation is suggested to help keep the heat out during summer (BRANZ 2005). Lane (1986) agrees and suggests super-insulating will reduce cooling requirements. Chiras (2002) suggests a radiant barrier such as an aluminium foil in the roof can reflect heat and stop it from entering the room. Chiras also suggests when insulation is used in conjunction with other passive design measures, wall and roof insulation will help keep the interiors cool in warm weather. Floor insulation is not considered important for cooling according to Chiras. Hastings and Wall (2007) suggest a high standard of insulation is required. However, Orme and Palmer (2003) are concerned that too much insulation traps heat inside through reducing heat losses and thus causing overheating.

Several different levels of insulation were tested in the modelling section of this work, including none, 1996 Code, and high by New Zealand standards.

\subsection{Thermal mass}

Thermal mass absorbs heat from the space. High levels of thermal mass reduce temperature fluctuation on a daily basis (Donn and Thomas 2001 and Hastings and Wall 2007). This is ideal in winter to prevent the house dropping to low temperatures overnight. However, to improve comfort during summer, cooling the thermal mass that has stored heat during the day needs to be cooled at night, so it is able to absorb more heat during the following day (Chiras 2002). Ideally the heat is not released into the house, allowing the house temperature to decrease at night ready for the heat loads the next day. This is commonly called night cooling. However, if there is not enough 
ventilation or the night air is not cool enough, the thermal mass will release the heat into the house.

The models had their thermal mass increased through concrete floors and to allow the mass to be effective the concrete was not carpeted. In the one house that was built with a concrete floor, the carpet was removed. All houses were modelled with concrete internal walls and a concrete floor.

\subsection{Airtightness of houses}

Chiras (2002) suggests it is important to reduce any infiltration, as any hot air entering a house through cracks contributes to heat gains. Passively designed homes should be designed and built airtight. Hastings and Wall (2007) suggest that to achieve a high performance building, the envelope needs to be airtight and use mechanical ventilation to ensure adequate fresh air supply, rather than relying on occupant controlled ventilation. However, the problems are occurring in everyday houses in New Zealand, not low energy passive design houses.

The models have been tested with increased and decreased levels of infiltration.

\subsection{Ventilation}

It is difficult for the household to cool if the extra heat is not able to escape; therefore ventilation is considered very important for preventing overheating in summer. The traditional method of cooling is through cross-ventilation (Pearson 1998). Using the prevailing winds, cool air enters the building at a low level and expels warm air through windows or vents at a high level. The thermal stack effect can be used to ventilate a house when there are no prevailing winds. The stack effect relies on a pressure 
difference at different openings. Again the air will enter at a low level and be expelled through a high opening. Chiras (2002) suggests different methods for ensuring good cross-ventilation such as:

- Window placement

- Open plan living

- Having a shaded courtyard to cool the air before it enters the house

- Window fans to increase air movement.

Both Chiras and Pearson (1998) recognise the benefits of night cooling to release the heat that has been stored during the day with cool night air. There are other methods such as wind scoops and earth cooling tubes, attic fans or whole house fans to increase the ventilation in warm humid or windless climates. Hastings and Wall (2007) suggest natural ventilation needs to be designed with care, as in a very airtight building the success is strongly user-dependent.

BRANZ (2005) suggests the following methods for increasing ventilation in New Zealand houses:

- Orientate for exposure to cooling breezes

- Reduce air path barriers through the building

- Provide fans for ventilation and air movement in the absence of breezes

- Maximise convective ventilation with high-level windows, ceiling and roof space vents

- Have windows open on security latch.

Mechanical ventilation at a controlled rate is a possibility, although not often found in New Zealand homes. Supply only ventilation systems are becoming increasingly 
common. However, most systems take air from the roof, so will not be suitable for cooling in summer. It may be possible to use these systems for night-time cooling.

The models have been tested with both higher and lower levels of ventilation than the base case.

\subsection{Internal heat gains}

Internal gains through heat generated by occupants and appliances are an added heat source inside the house. The internal gains are largely determined by the occupants in the house. However, some decisions made at the design stage influence where the internal gains are in the house. For example:

- The location of the hot water heater

- The location of the laundry

- The kitchen in relation to the rest of the house

- An internal access garage allows the heat from the garage into the house

- The amount of lights in the house.

Occupants' choices affect many of the internal gains. Chiras (2002) suggests reducing internal gains by: occupants using appliances late at night or earlier in the morning; shifting the appliances outdoor; or sealing off heat sources and venting outside.

The models were tested with increased and decreased levels of internal gains. 


\subsection{Site selection}

The selection of the site determines the amount of solar gains and wind that the house will receive. For overheating, shading can be built into the design (Donn and Thomas 2001). In New Zealand it is accepted that good orientation is towards the sun, to take advantage of solar gains during winter and good daylighting (SmarterHomes 2008 and Elkink 2008). Good orientation should also consider cooling breezes for summer (SmarterHomes 2008). Chiras (2002) considers the orientation to be one of the most important considerations for preventing overheating, and the warmer the climate the more important this becomes if passive cooling is the goal.

For this work each house was modelled in its 'as built' orientation as well as the living room orientated towards north.

\subsection{Combining methods}

Combinations of features have not been modelled in this work. However, this is an area that could be explored further. Chiras (2002) suggests that many features make a small difference by themselves, but combined they may make a large difference. This is suggested as an area where further research could be conducted. 


\section{Thermal modelling to determine which features contribute to overheating}

This section discusses the process of modelling five houses in the thermal modelling tool SUNREL (Deru et al 2002) and validating them. Using validated models ensures the outputs are as realistic as possible. The models features are altered one at a time to determine which features cause the increasing temperatures. The changes made are based on the known features that have changed in houses over time and the features known to influence temperatures (Chapters 5 and 6). The results of these changes are given in Chapter 8.2.

The five thermal models are based on monitored houses. Modelling monitored houses means the models can be validated. However, there are always limits to how realistic a house can be modelled, particularly when modelling an occupied house. Assumptions were made about occupants' actions and the physical house as explained in the following section.

The five houses modelled were chosen from Auckland, New Zealand (latitude $-37^{\circ}$ and longitude $174.7^{\circ}$ ). A number of features of the house and occupants were considered before modelling, therefore resulting in a range of house and occupant types.

Modelling of the houses was completed using information from the HEEP database, including house audit information and occupant survey data. Steps were made to ensure the models are as realistic as possible, such as scheduled opening and closing of windows, ventilation and appropriate internal gains based on measured data. Due to modelling limitations, it is always only possible to give a representation of the house and the conditions. 
Key features of the houses are given in Table 12. All houses can be considered relatively lightweight.

\begin{tabular}{|c|c|c|c|c|c|}
\hline $\begin{array}{l}\text { House } \\
\text { number }\end{array}$ & One & Two & Three & Four & Five \\
\hline Floor area & $69 \mathrm{~m}^{2}$ & $278 \mathrm{~m}^{2}$ & $87 \mathrm{~m}^{2}$ & $195 \mathrm{~m}^{2}$ & $245 \mathrm{~m}^{2}$ \\
\hline House age & $1940 s$ & 1982 & 1960s & 1964 & $\begin{array}{c}\text { 1930s, 1950s, } \\
1960 \text { s and } \\
2002^{8}\end{array}$ \\
\hline Occupants & 2 & 2 & 3 & 2 & 5 \\
\hline Levels & $1 \& 1 / 2$ & $1 \& 1 / 2$ & 1 & 3 & 2 \\
\hline Floor & $\begin{array}{l}\text { Timber with } \\
\text { perimeter wall }\end{array}$ & Concrete & $\begin{array}{c}\text { Timber with } \\
\text { perimeter } \\
\text { wall }\end{array}$ & Timber & $\begin{array}{c}\text { Timber up, } \\
\text { concrete down }\end{array}$ \\
\hline Walls & $\begin{array}{l}\text { Timber frame, } \\
\text { weatherboard }\end{array}$ & $\begin{array}{c}\text { Concrete } \\
\text { block lower, } \\
\text { brick veneer } \\
\text { upstairs }\end{array}$ & $\begin{array}{l}\text { Timber } \\
\text { frame, } \\
\text { weather- } \\
\text { board }\end{array}$ & $\begin{array}{c}\text { Timber } \\
\text { frame, } \\
\text { weather- } \\
\text { board, } \\
\text { concrete } \\
\text { block for } \\
\text { lower level }\end{array}$ & $\begin{array}{l}\text { Timber frame, } \\
\text { weatherboard } \\
\text { upstairs, brick } \\
\text { veneer below }\end{array}$ \\
\hline Insulation & None & Roof only & Roof only & $\begin{array}{c}\text { Walls and } \\
\text { roof }\end{array}$ & $\begin{array}{c}2002 \text { addition } \\
\text { only }\end{array}$ \\
\hline Glazing & Single & Single & Single & Single & Single \\
\hline
\end{tabular}

8 Four major additions were done to the house in these years. 


\begin{tabular}{|c|c|c|c|c|c|}
\hline $\begin{array}{l}\text { Window } \\
\text { frames }\end{array}$ & Timber & Aluminium & Timber & Aluminium & Timber \\
\hline $\begin{array}{l}\text { Window-to- } \\
\text { wall ratio }\end{array}$ & $12 \%$ & $26 \%$ & $23 \%$ & $27 \%$ & $26 \%$ \\
\hline Airtightness $^{9}$ & Draughty & Airtight & Average & Average & Leaky \\
\hline $\begin{array}{l}\text { House } \\
\text { condition }\end{array}$ & Average & $\begin{array}{l}\text { Reasonably } \\
\text { good }\end{array}$ & Average & $\begin{array}{l}\text { Reasonably } \\
\text { good }\end{array}$ & $\begin{array}{c}\text { Well below } \\
\text { average }\end{array}$ \\
\hline $\begin{array}{l}\text { House } \\
\text { eaves }\end{array}$ & $\begin{array}{c}\text { Between } \\
0.3-1.3 \mathrm{~m}\end{array}$ & $\begin{array}{l}\text { Between } \\
1.3-3 \mathrm{~m}\end{array}$ & $\begin{array}{l}\text { Between } \\
0.3-1.3 \mathrm{~m}\end{array}$ & $\begin{array}{l}\text { Between } \\
0.3-1.3 \mathrm{~m}\end{array}$ & $\begin{array}{c}\text { Between } \\
0.3-1.3 \mathrm{~m}\end{array}$ \\
\hline $\begin{array}{l}\text { Living room } \\
\text { orientation }\end{array}$ & West & East & West & $\begin{array}{c}\text { South, West } \\
\text { and East }\end{array}$ & North-East \\
\hline
\end{tabular}

Table 12: Description of houses modelled

\subsection{Modelling assumptions}

Assumptions were made for both the occupants' activities and for unknowns about the house construction or design. Table 13 summarises assumptions affecting internal temperatures.

\begin{tabular}{|l|lllll|}
\hline House number & One & Two & Three & Four & Five \\
\hline Internal gains (day) & $0.34 \mathrm{kWh}$ & $1.08 \mathrm{kWh}$ & $0.51 \mathrm{kWh}$ & $0.62 \mathrm{kWh}$ & $0.95 \mathrm{kWh}$ \\
Internal gains (night) & $0.30 \mathrm{kWh}$ & $0.61 \mathrm{kWh}$ & $0.41 \mathrm{kWh}$ & $0.41 \mathrm{kWh}$ & $0.79 \mathrm{kWh}$ \\
Internal furnishings & $2,760 \mathrm{~kg}$ & $11,120 \mathrm{~kg}$ & $3,480 \mathrm{~kg}$ & $7,800 \mathrm{~kg}$ & $9,800 \mathrm{~kg}$ \\
Venting set-point (summer) & $25^{\circ} \mathrm{C}$ & $25^{\circ} \mathrm{C}$ & $25^{\circ} \mathrm{C}$ & $25^{\circ} \mathrm{C}$ & $25^{\circ} \mathrm{C}$ \\
Venting (summer) & $40 \mathrm{ac} / \mathrm{h}$ & $40 \mathrm{ac} / \mathrm{h}$ & $40 \mathrm{ac} / \mathrm{h}$ & $40 \mathrm{ac} / \mathrm{h}$ & $40 \mathrm{ac} / \mathrm{h}$ \\
Infiltration & $1.1 \mathrm{ac} / \mathrm{h}$ & $0.5 \mathrm{ac} / \mathrm{h}$ & $1 \mathrm{ac} / \mathrm{h}$ & $0.67 \mathrm{ac} / \mathrm{h}$ & $0.8 \mathrm{ac} / \mathrm{h}$ \\
\hline
\end{tabular}

9 Occupant reported. 


\section{Table 13: Summary of assumptions}

\subsubsection{Zones}

Each house was modelled by zones (see Appendix B for floor plans by zones). Within each zone was either one room or a group of rooms. The living room was always a separate zone, with the rest of the house divided as appropriate. Generally each model has the following zones: living room, bedroom, hallway, bathroom, attic and under-floor (in timber floor houses). The attic zone is modelled in the pitched roof houses (all but one of the houses). This allows air to be modelled between the ceiling and the roof, as the under-floor zone allows air flow under the house.

\subsubsection{Material properties}

To ensure heat storage and resistance is modelled correctly, all materials with thermal storage are modelled using their mass properties. For example, plasterboard is modelled by entering the values for conductivity, density, specific heat, material thickness and number of nodes instead of an R-value. This allows the material to store and release heat. Only materials with little heat storage (e.g. metal roofing and carpet) were entered as an R-value. Air was entered as an R-value of 0.18 - this is considered an appropriate value for air in an enclosed space such as walls and attic spaces. ${ }^{10}$

Generic material properties were taken from Standards New Zealand (2006). In some cases it was necessary to make assumptions about materials used. In these cases

10 Personal communication with lan Cox-Smith, BRANZ Ltd Thermal Testing Scientist, August 2006. 
Eddie Bruce ${ }^{11}$ was consulted to check construction materials and thicknesses were appropriate, in conjunction with Standards New Zealand (1999), and product brochures. For example there are multiple weatherboard claddings available, therefore a commonly used product was chosen. Ply flooring was used instead of particle board flooring, as particle board will not be given consent in some locations due to moisture issues. However, the difference in R-values between the two is just 0.003 . To ensure the material properties are realistic all materials used were checked to ensure they can be purchased in the modelled thickness and properties.

\subsubsection{Internal furnishings}

Furniture, books, bedding and clothing all contribute to the thermal mass of the house. This thermal mass is occupant dependent, spread throughout the house, differs between houses and is hard to measure. This can be accounted for by adding more thermal mass to a room and was done by placing extra internal walls in the houses. Adding extra walls has the advantage of being able to place an appropriate amount of extra mass in each zone. The addition of internal walls within a zone does not affect the interior temperature, as SUNREL assumes air is well mixed within each zone (Deru et al 2002).

The amount of extra thermal mass due to the furnishings etc in the house can be considered the same as the live load of the house. This does vary by house; therefore a range of weights were tested to determine the effect different amounts of thermal mass have. The range tested was from $15 \mathrm{~kg} / \mathrm{m}^{2}$ to $40 \mathrm{~kg} / \mathrm{m}^{2}$. This weight was

11 Personal communication with Eddie Bruce, BRANZ Ltd Industry Helpline, August and September 2006. 
determined by the design allowances in the NZBC. The NZBC requires houses to be built to hold $1.5 \mathrm{Kpa}$, which equates to $150 \mathrm{~kg} / \mathrm{m}^{2}$. A safety factor of 1.5 is then added; $1.5 \mathrm{Kpa}$ is at the upper limit and can be reduced for large spaces.

It can be assumed in an average house that the weight of the furnishings is approximately $10 \%$ of the requirements (or $15 \mathrm{~kg} / \mathrm{m}^{2}$ ). ${ }^{12}$ This weight is the live load only e.g. furniture and occupants inside the building with the walls not included. For the upper limit $40 \mathrm{~kg} / \mathrm{m}^{2}$ was chosen, due to this being the weight used for seismic testing at BRANZ Ltd. ${ }^{13}$ The upper limit of $40 \mathrm{~kg} / \mathrm{m}^{2}$ was chosen for the final models as there was little temperature difference seen between the $15 \mathrm{~kg} / \mathrm{m}^{2}$ and $40 \mathrm{~kg} / \mathrm{m}^{2}$.

The total weight of extra mass required for each house was based on the floor area. With the weight of the wall known the correct dimensioned wall was then added, giving the overall amount of extra thermal mass in the house. The garages and basements were excluded from calculating the extra mass required. To calculate the dimensions of the wall representing the mass of the furnishings, the weight of a typical timber-framed, plasterboard wall was calculated from the mass properties of the materials. The wall weight was calculated to be $22 \mathrm{~kg} / \mathrm{m}^{2}$ (two pieces of plasterboard and studs), given that:

- Plasterboard weighs $-8 \mathrm{~kg} / \mathrm{m}^{2}$ (one piece of plasterboard)

- Studs weigh $-6 \mathrm{~kg} / \mathrm{m}^{2}$ (assuming studs comprise $12 \%$ of the wall).

12 Personal communication with Simon Burrough, Clendon, Burns and Park, Consulting Structural Engineer, April 2007.

13 Personal communication with Roger Shelton, BRANZ Ltd Senior Structural Engineer, and Nigel Isaacs, BRANZ Ltd Principal Scientist, April 2007. 


\subsubsection{Walls, roof and floor}

The wall, roof and floor types were first constructed in the wall type section of SUNREL. In the wall types each wall is given a name, then the wall, roof or floor is constructed in layers from inside to outside. Each layer uses the names of the material from the mass properties descriptions or an R-value. Some typical walls are detailed in Table 14. All non-solid walls, floors and ceilings were entered as composite walls. This was done as SUNREL models heat transfer two-dimensionally. For example walls were modelled as two separate walls, with the same interior and exterior surface and dimensions. Each separate part of the wall is entered as a percentage equalling 100 . This allows the insulation and timber studs (causing thermal bridging) to be represented. The BRANZ House Insulation Guide (Tims 2007) shows the effect the different timber-to-air/insulation ratios have on the overall thermal performance. For a typical New Zealand timber-framed house with $100 \mathrm{~mm}$ walls, the following ratios of timber-to-air or insulation were used as determined by lan Cox-Smith: 14

- Walls - studs $18 \%$, cavity $82 \%$

- Timber floor - joists $10 \%$, cavity $90 \%$

- Ceiling - joists $12 \%$, cavity $88 \%$

- Roof - rafters $10 \%$, cavity $90 \%$.

The exterior wall's solar reflectivity value used was 0.3 - a medium to light-coloured wall. All exterior surfaces were modelled to allow them to receive solar gains.

14 Personal communication with Dr lan Cox-Smith, BRANZ Ltd Thermal Testing Scientist, August 2006. 


\begin{tabular}{|l|cccc|}
\hline Element & \% of wall & Layer 1 & Layer 2 & Layer 3 \\
\hline Wall external & 82 & Plasterboard & Air/lnsulation & Cladding \\
& & & & \\
\hline Wall external & 18 & Plasterboard & Timber stud & Cladding \\
\hline Floor timber & 90 & Carpet & Plywood & Air/Insulation \\
\hline Floor timber & 10 & Carpet & Plywood & Joist \\
\hline
\end{tabular}

Table 14: Typical wall and floor construction

Concrete slab floors are difficult to model in a two-dimensional thermal modelling tool. This is due to heat transfer not only going through the slab, but sideways at the edges. The concrete slab floors were modelled in the suggested method in the SUNREL manual (Deru et al 2002). For the purposes of modelling, concrete floors have been treated as having a perimeter area of $1 \mathrm{~m}$. This allows the heat loss to go through to the ground, and out to the air (outwards from the slab), and a middle area where the heat loss is straight down into the ground.

All the timber floor models have a perimeter wall and an under-floor zone.

For pitched roofs the ceiling, roof and attic were modelled.

\subsubsection{Insulation}

Insulation was modelled by an R-value in the appropriate layer of the wall, floor or ceiling (see Table 14). During the HEEP installation, the roof and under-floor spaces were examined where possible, with estimates made of the type and thickness of insulation. The R-value for modelling was estimated using the field information and the age of the house. 


\subsubsection{Glazing}

Windows were modelled using the glazing types page in SUNREL. The R-value used for single glazed windows was 0.15 (Standards New Zealand 2004) with an extra 0.5 for curtains (Stoecklein and Bassett 2000). Curtains were added between the hours of $11 \mathrm{pm}$ and 7 am using a schedule. Windows modelled with curtains were in the bedroom, living and dining rooms. Utility room windows were not modelled with curtains.

\subsubsection{Internal gains}

Internal gains were calculated for each house based on the floor size, number of occupants, and number of hot water cylinders (Table 15). Appropriate internal gains were determined from HEEP analysis. ${ }^{15}$ All gains from occupants during the day were in the living room and in the bedrooms during the night. Equipment gains were evenly distributed throughout the house, except from the hot water cylinder gains, which were modelled in the appropriate zone.

15 Personal communication with Michael Camilleri, BRANZ Ltd Senior Scientist (HEEP), August 2007. 


\begin{tabular}{|l|ll|}
\hline & Daytime & Night-time \\
\hline Hours & $7: 00-23: 00$ & $23: 00-7: 00$ \\
Occupancy & $75 \mathrm{~W}$ per person & $75 \mathrm{~W}$ per person \\
Equipment gains & $3 \mathrm{~W} / \mathrm{m}^{2}$ & $1.5 \mathrm{~W} / \mathrm{m}^{2}$ \\
Hot water cylinder losses & $100 \mathrm{~W}$ per cylinder & $50 \mathrm{~W}$ per cylinder \\
\hline
\end{tabular}

Table 15: Calculation of internal gains

\subsubsection{Ventilation}

SUNREL has the choice of natural ventilation, and venting through fans at a specified set-point air change rate. The set-point can be scheduled by the time of day and year. The set-point and air change rate were estimated, but several values were tested. Only the zones with opening windows to the outside are vented. Natural ventilation in SUNREL was not used, due to insufficient data. The venting temperature set-point was set to $25^{\circ} \mathrm{C}$, with the venting level at $40 \mathrm{ac} / \mathrm{h}$. This was set through discussions, ${ }^{16}$ research (Garde et al 2001) and experimentation with the models.

\subsubsection{Air leakage/infiltration}

Measuring air leakage requires a blower door test. The houses modelled were not able to have their air leakage measured, due to the expense in time and money. However, with the physical information collected on the house, and the occupant-reported assessment of air leakage (asked in the survey), assumptions were made for the average air leakage of each house. The infiltration levels (Table 13) were calculated using BRANZVENT. ${ }^{17}$ Four $\mathrm{ac} / \mathrm{h}$ in the subfloor were modelled, as this is the

16 Personal communication with Francois Garde, Laboratory of Building Physics and Systems, University of Reunion Island, July 2007.

17 BRANZVENT is a method of calculating infiltration and ventilation in houses developed by Mark Bassett. BRANZVENT is unpublished at present. Therefore the calculation was performed 
suggested value from Mark Bassett through his work measuring air changes in the subfloor. ${ }^{18}$

\subsubsection{Skyline}

Entering a skyline allows modelling of obstructions such as neighbouring houses/buildings, hills or trees preventing the sun from reaching the house. SUNREL splits the horizon into 11 sections centred on north for a southern hemisphere model (south for a northern hemisphere model - see Appendix D). Shading on the south side is ignored. The horizon is the altitude angle in degrees of the skyline at each of the 11 sections (Deru et al 2002). The values for the skyline were determined by examining the exterior photographs of the houses.

\subsubsection{Solar distribution}

The percentage of solar gains each surface inside a zone receives was specified. Careful consideration was given to the size and direction of the windows, to determine the surfaces receiving sun, and the solar gain was (??) divided as a result.

\subsubsection{Weather data}

The external temperatures are known to have the largest effect on internal temperatures in New Zealand houses (French et al 2007b). Accurate weather data is

through personal communication with Mark Bassett, BRANZ Ltd Principal Scientist, August 2006.

18 Personal communication with Mark Bassett, BRANZ Ltd Principal Scientist, August 2006. 
therefore vital to calculate the internal temperature accurately. For this reason, it was decided to develop a weather file for the period of which the houses were monitored, rather than using available TMY weather files. The format used for creating the weather file was SUNREL, outlined in the SUNREL manual (Deru et al 2002). The weather file was created from monitored NIWA data, available from the CLIFLO database (Penny 2003). The details of the two weather stations used are shown in Table 16. The Owairaka weather station was considered most representative of the houses modelled. Unfortunately, only the temperature data was available from Owairaka station. The Khyber Pass station was therefore used for the remaining data. The Khyber Pass station is in a commercial area of Auckland compared to Owairaka station, which is in a residential area.

\begin{tabular}{|c|c|c|c|c|c|}
\hline $\begin{array}{l}\text { Weather } \\
\text { station }\end{array}$ & $\begin{array}{l}\text { Agent } \\
\text { number }\end{array}$ & Latitude & Longitude & $\begin{array}{l}\text { Height } \\
\text { above sea } \\
\text { level }\end{array}$ & Data used \\
\hline $\begin{array}{l}\text { Khyber Pass, } \\
\text { Auckland }\end{array}$ & 22164 & -36.87 & 174.78 & $81 \mathrm{~m}$ & $\begin{array}{l}\text { Solar radiation, } \mathrm{RH} \text {, } \\
\text { wind direction and } \\
\text { speed }\end{array}$ \\
\hline $\begin{array}{l}\text { Owairaka, } \\
\text { Auckland }\end{array}$ & 1468 & -36.893 & 174.726 & $41 \mathrm{~m}$ & $\begin{array}{l}\text { Temperature data - dry- } \\
\text { bulb }\end{array}$ \\
\hline
\end{tabular}

Table 16: Weather station descriptions (Penny 2003)

The beam radiation was calculated from the global horizontal, as it is not measured in a location representative of the houses in Auckland. Two methods were tested Maxwell (1987) and Erbs et al (1982). The results were compared and the Erbs method was decided to represent the expected beam radiation the best (this was supported by Perez et al 2001). The dew-point temperature was calculated, using the $\mathrm{RH}$ and dry-bulb temperature data in equations from ASHRAE Fundamentals (Owen 
2005). The ground temperatures required for Auckland were taken from Ministry of Transport (1983) average monthly temperatures for a depth of $1 \mathrm{~m}$. The ground temperature values were not available for the period the houses were monitored, so average values were used. The ground temperature for each month was entered as a schedule into SUNREL.

Table 17 gives the monthly outputs from SUNREL for the temperatures, and the heating and cooling degree days. See Appendix $C$ for radiation and wind data. 


\begin{tabular}{|c|c|c|c|c|c|c|}
\hline \multirow[b]{2}{*}{ Month } & \multicolumn{4}{|c|}{ Temperature } & \multicolumn{2}{|c|}{$\begin{array}{c}\text { Degree days (base } \\
\left.15^{\circ} \mathrm{C}\right)\end{array}$} \\
\hline & $\begin{array}{c}\text { Mean } \\
{ }^{\circ} \mathrm{C}\end{array}$ & $\begin{array}{c}\text { Minimum } \\
{ }^{\circ} \mathrm{C}\end{array}$ & $\begin{array}{c}\text { Maximum } \\
{ }^{\circ} \mathrm{C}\end{array}$ & $\begin{array}{c}\text { Range } \\
{ }^{\circ} \mathrm{C}\end{array}$ & Heating & Cooling \\
\hline January & 18.8 & 10.8 & 24.6 & 6.3 & 0 & 36 \\
\hline February & 19.1 & 13.5 & 25.4 & 5.7 & 0 & 41.9 \\
\hline March & 18.7 & 14.0 & 24.4 & 4.8 & 0 & 30.7 \\
\hline April & 16.4 & 9.0 & 21.2 & 5.1 & 3.6 & 2.5 \\
\hline May & 14.8 & 8.5 & 19.1 & 4.5 & 17.8 & 0.1 \\
\hline June & 13.4 & 7.1 & 19.2 & 4.5 & 50.3 & 0 \\
\hline July & 10.4 & 4.3 & 15.3 & 5.1 & 137.9 & 0 \\
\hline August & 11.5 & 6.0 & 16.7 & 4.6 & 104.9 & 0 \\
\hline September & 13.0 & 7.8 & 19.2 & 4.8 & 58.9 & 0 \\
\hline October & 13.5 & 7.0 & 20.1 & 5.4 & 51.4 & 0 \\
\hline November & 14.9 & 9.1 & 20.2 & 5.1 & 21.5 & 0.2 \\
\hline December & 18.1 & 11.6 & 24.5 & 5.3 & 0.1 & 27 \\
\hline Total & 15.17 & 4.3 & 25.4 & 5.1 & 446.5 & 138.3 \\
\hline
\end{tabular}

Table 17: Weather data summary from SUNREL

\subsection{Calculation of temperature in models}

The temperature generated by SUNREL needs to be comparable to the temperatures experienced in the house. For this work the central zone temperature from SUNREL has been used for the living room air temperature. SUNREL is a multi-zone modelling tool, with one temperature calculated per zone. The central zone temperature (reported air temperature for the zone) is not the air temperature, but a conductance-weighted average of the temperatures affecting the zone (Deru et al 2002). 
In some circumstances the central node temperature might differ significantly from the true air temperature. Muncey (1979) showed the resulting error in temperature is typically comparable to that produced by differences in radiation transfer, resulting from the detailed modelling of furniture in the zone. The generated air temperature from SUNREL is therefore considered to be a close representation of the temperatures in the houses. To eliminate occurrences where there may be differences an average temperature over a period of weeks is used for the thermal modelling work.

SUNREL assumes the air is well mixed within the zone, and the temperature is the same throughout the space. In reality there can be large differences in a space due to gains and losses, or air flow disrupted by furniture. If there are walls within the zone this will affect the flow of air, and the temperatures are likely to be different between places within the zone. This is not taken into consideration in the SUNREL calculation.

\subsection{Validating the models}

The models were validated by comparing the monitored data (HEEP) to the data generated by the models. It is difficult to say what temperature difference between the model and monitored data is acceptable. The temperatures from the models and monitored data were therefore converted to comfort measurements which were then compared. For example an average temperature difference of $1^{\circ} \mathrm{C}$ means little, compared to $40 \%$ more of the occupants being dissatisfied in the environment.

The comfort measurement used is calculated according to Fanger's PMV and PPD method (Fanger 1970). This work is however about comparing models with measured data, rather than deciding if the houses are comfortable or not. Using this comfort 
measurement, the results of both the monitored and modelled houses are evaluated, testing the model's representation of reality. The PPD has an advantage over straight temperature comparisons by allowing the difference in the thermal sensation of the occupants to be compared, instead of a temperature difference that has an unknown effect on the comfort of the occupants. See Appendix E for more information on PMV and PPD.

\subsubsection{Calculating the PMV}

The PMV index is calculated from activity (metabolic rate), the clothing value (thermal resistance), air temperature, mean radiant temperature, relative air velocity and partial water vapour pressure. The full calculations can be seen in Appendix E. Table 18 gives the constant variables used to calculate the PPD. The measured variables that change with time are shown as three dashes (---). For all values except those relating to temperature and $\mathrm{RH}$, the same value is used when calculating the PPD for the models and the monitored houses. $\mathrm{RH}$ was not measured, therefore the partial water vapour was calculated by using the dew-point (Penny 2003). The $\mathrm{RH}$ was calculated and a conversion made for the inside temperature to give the approximate $\mathrm{RH}$. This is based on the assumption that the outside air is holding the same amount of moisture as the inside air. This should be close to reality in a well-vented house in New Zealand during summer. The moisture produced from occupants, pets, plants and equipment inside the house is unknown, and will differ by house, time of year and day. 


\begin{tabular}{|l|lcc|}
\hline Symbols & Variables & Values & Units \\
\hline CLO & Clothing & 0.5 & Clo \\
MET & Metabolic rate & 1.2 & met \\
WME & External work & 0 & met \\
TA & Air temperature & --- & ${ }^{\circ} \mathrm{C}$ \\
TR & Mean radiant temperature & --- & ${ }^{\circ} \mathrm{C}$ \\
VEL & Relative air velocity & 0.1 & $\mathrm{~m} / \mathrm{s}$ \\
RH & Relative humidity & --- & $\%$ \\
PA & Water vapour pressure & --- & $\mathrm{Pa}$ \\
\hline
\end{tabular}

Table 18: PMV variables and values

The PMV and PPD equations were written as functions in Visual Basic. This allowed multiple PMVs to be calculated at one time, using hourly temperature data from both the modelled houses and the monitored data (see Table 19).

\subsubsection{Calculating the PPD}

The PPD was calculated once the PMV was known (Equation 2). Figure 24 shows the relationship between PMV and PPD. Appendix E explains the relationship and gives the calculations.

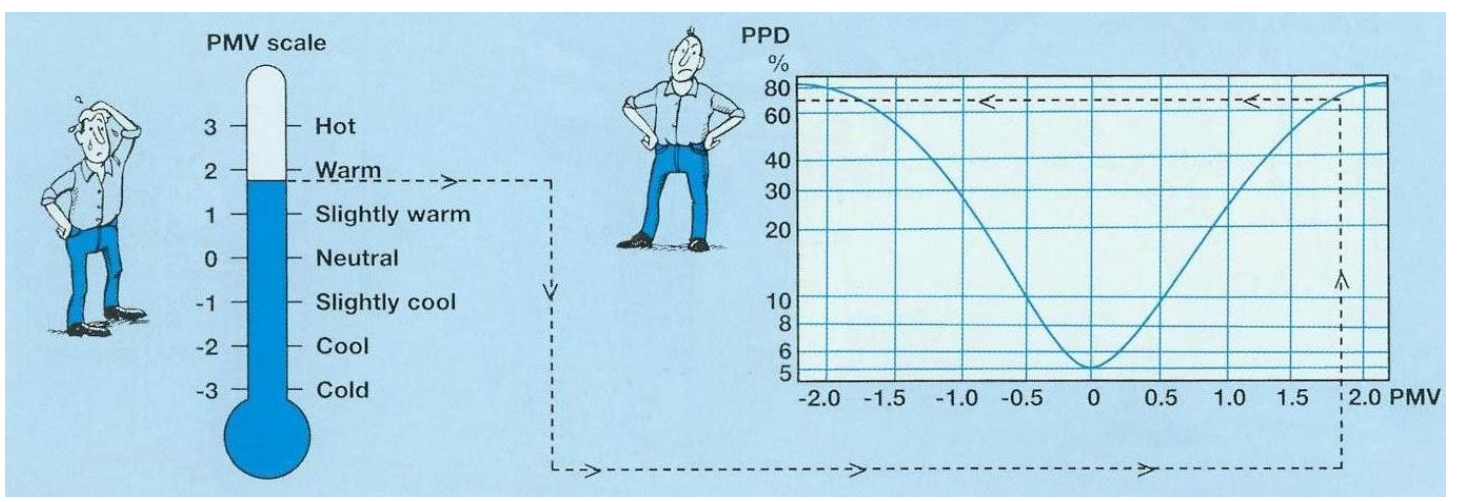

Figure 24: PMV and PPD relationship (Innova 2007) 
The PPD indices predict the number of thermally dissatisfied people in a large group. The further the PMV is away from neutral (0), the higher the number of people who are thermally dissatisfied. The percent of people thermally dissatisfied is never below $5 \%$. Even if all people are dressed similarly, and are performing the same activity, there will be still some individuals who are dissatisfied with the environment.

Table 19 gives an example of calculated PMVs and PPDs (in grey) for hourly external temperatures and dew-points for a few hours in January.

\begin{tabular}{|ccccccc|}
\hline Dew-point & Absolute & Air & Water & vapour & PMV & PPD \\
temperature $\left({ }^{\circ} \mathbf{C}\right)$ & dew-point & temperature & pressure (Pa) & & $(\%)$ \\
& $(\mathrm{K})$ & $\left({ }^{\circ} \mathbf{C}\right)$ & & & \\
\hline 11.8 & 284.95 & 20.1 & $1,384.2$ & -1.6 & 56.4 \\
11.8 & 284.95 & 21.4 & $1,384.2$ & -1.2 & 36.2 \\
11.8 & 284.95 & 22.0 & $1,384.2$ & -1.0 & 27.9 \\
11.8 & 284.95 & 22.1 & $1,384.2$ & -1.0 & 26.7 \\
11.9 & 285.05 & 22.2 & $1,393.4$ & -1.0 & 25.4 \\
11.9 & 285.05 & 23.3 & $1,393.4$ & -0.7 & 14.6 \\
11.9 & 285.05 & 23.1 & $1,393.4$ & -0.7 & 16.2 \\
11.7 & 284.85 & 22.5 & $1,375.1$ & -0.9 & 21.9 \\
11.7 & 284.85 & 22.4 & $1,375.1$ & -0.9 & 23.1 \\
11.9 & 285.05 & 21.4 & $1,393.4$ & -1.2 & 36.2 \\
11.9 & 285.05 & 21.1 & $1,393.4$ & -1.3 & 40.6 \\
& & & & &
\end{tabular}

Table 19: An example of calculated PMVs and PPDs 


\subsubsection{Validation results}

The models were validated by comparing the model's PPD data to the monitored PPD data. The data was compared for the first three weeks of January 2003. For all houses the monitored energy data was examined to check the occupants were at home during this time, rather than on holiday. There are also several days for all houses where the occupants are not at work. This is relevant as occupants may be actively controlling ventilation when at home. However, by comparing data over time the results will average out. Figure 25 gives an example of PPDs for both the monitored and the model data for the first 300 hours in January 2003.

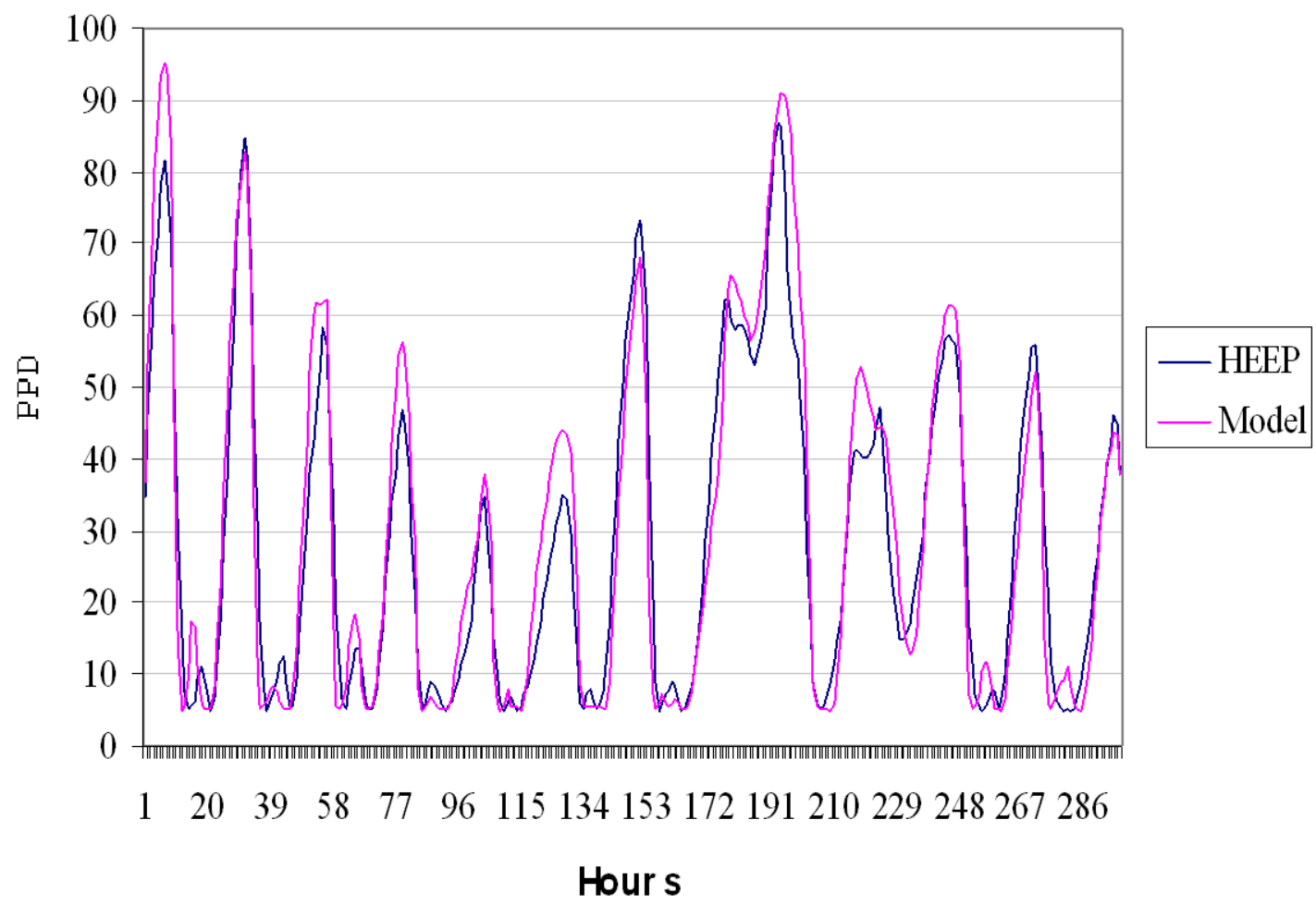

Figure 25: PPD for House one - first 300 hours of January

Figure 26 shows the relationship between the calculated PPD and the monitored PPD for house one. Figure 27 shows the relationship between the calculated temperature 
and the monitored temperature. In Figure 27 in can be seen the windows in the model open at $25^{\circ} \mathrm{C}$. The model is more likely to overestimate temperature rather than under.

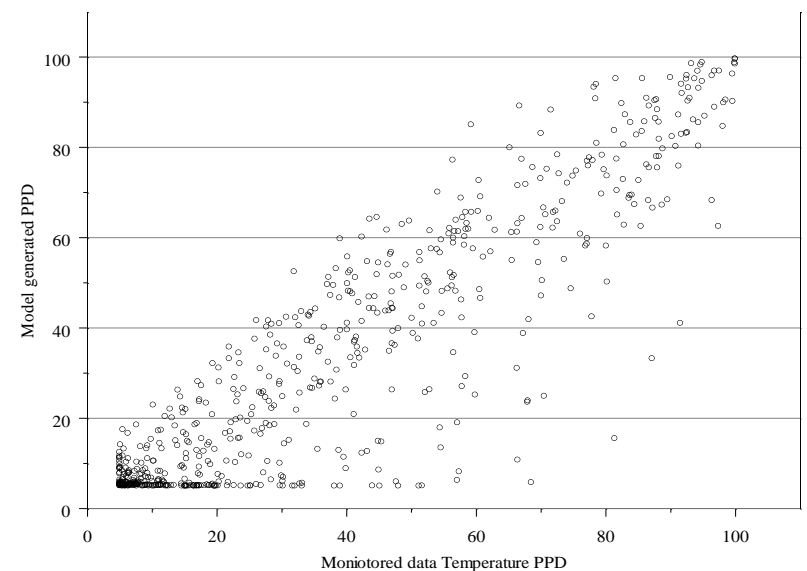

Figure 26: PPD correlation for House one - PPD

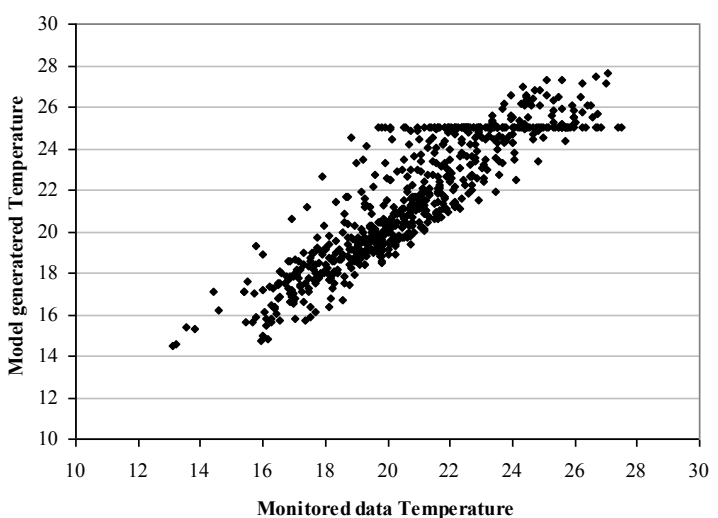

Figure 27: Temperature correlation $\left({ }^{\circ} \mathrm{C}\right)-$ House one

A paired T-test was used to determine the differences between the monitored and the model's PPD values for each house (Table 20). House Two had the largest average difference between the model and monitored data at $6 \%$. A negative difference (House five) means the model predicts a higher PPD than the monitored data.

\begin{tabular}{|l|ccc}
\hline House & Lower range (\%) & Upper range (\%) & Average (\%) \\
\hline One & 3.7 & 5.6 & 4.6 \\
Two & 5.3 & 6.7 & 6.0 \\
Three & 1.0 & 2.8 & 1.9 \\
Four & 3.4 & 5.7 & 4.6 \\
Five & -4.7 & -1.6 & -3.2 \\
\hline
\end{tabular}

Table 20: Paired T-test results 
Although the results are not statistically the same, the variation is small. A difference of $\pm 5 \%$ is considered acceptable considering the PPD method only goes as low as $5 \%$ due to some people never being satisfied (Fanger 1970). 


\section{Changes in design and construction that are causing overheating}

The following section summarises the changes that cause the indoor temperature to increase. Results are given from analysis of monitored data and thermal modelling.

The HEEP database has monitored temperature data for a representative sample of New Zealand houses for a year. New Zealand is the only country to have a representative database like this. The database was used in this work as much as possible, to ensure results are relevant to occupied New Zealand houses. However, there are limitations with analysing data from real houses. First, the occupants cannot be controlled. Occupants will open and close windows affecting ventilation rates, which can have a large effect on the indoor temperature. The database does not hold information on the occupants actions, so there is potential for unknown activities happening that affect the indoor temperature. Another issue when analysing real data is that every house is different. It is not possible to group houses that are exactly the same, because there are no two the same and this limits the analysis that can be done. For these reasons thermal modelling of five monitored houses was done to complete this work.

Thermal modelling has the advantage of everything being controlled. Five houses were modelled in the thermal design software SUNREL as explained in Chapter 7. These five houses were validated by checking the output against monitored data, ensuring the models are realistic. The models then had one feature altered at a time determining the effect the feature has on the indoor temperature. An average temperature difference was calculated between the new average maximum temperature and the base models 
maximum temperature for the first three weeks in January 2003. The same features were changed in all models and the average temperature difference compared.

\subsection{Results from monitored data}

The HEEP database was examined to determine which features of new houses are causing the indoor temperatures to increase. Due to the variation in the sample it is difficult to conclusively say what elements of new houses are causing the increasing temperatures. However, four features were found to have a marginal influence for explaining the temperature increase. They are:

- Glazing area - the higher the percent of north, west and east glazing of the north, west and east walls, the higher the temperature

- Increasing thermal insulation - it is difficult to accurately determine the R-value of the houses; however, the more insulation the higher the interior temperature is likely to be

- Airtightness of the house - the more airtight the house the warmer the temperature. It was not possible to measure ventilation in the houses - ventilation is expected to have an influence given the influence of airtightness

- Eave size - the smaller the eave the higher the temperature. However, due to eave size being estimated rather than measured, it is not possible to say how significant eave size is.

The influences on indoor temperatures were determined by linear modelling in the statistical analysis program S-Plus. 


\subsubsection{Glazing area}

Glazing area has been found to be increasing in new houses in both the literature study and the HEEP database. Increasing the glazing area increases the amount of solar gains entering and therefore increasing the indoor temperature. As the temperature increase does not appear to relate just to glazing size, it is thought that perhaps the occupants have adapted their actions to compensate for the higher solar gains. For example, the occupants might have extra shading in summer either externally or internally through curtains or blinds, or they may have higher air flow rates through opening more windows and perhaps using fans. There are many interactions that could be happening to prevent the glazing area being statistically significant.

\subsubsection{Insulation}

Figure 28 gives the mean living room temperature for all houses by pre and post-1978, when insulation became mandatory in New Zealand. Some pre-1978 houses in this sample do have insulation, but it is generally only in the ceiling and often to a lower level than what is required for post-1978 houses.

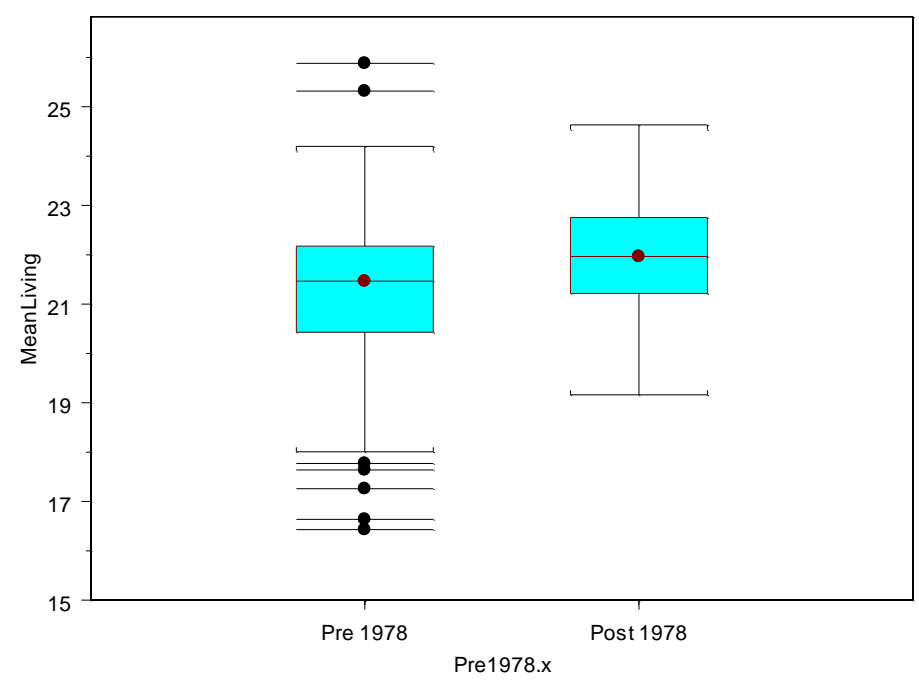

Figure 28: Mean living room day temperatures by insulation requirements 
The mean living room temperature for pre-1978 houses is $21.3^{\circ} \mathrm{C}$ and for post- 1978 houses $22.0^{\circ} \mathrm{C}$ (Table 21). Given there is large variation in the amounts of insulation in both groups, it is hard to be certain of the effect the presence of insulation has on temperatures.

\begin{tabular}{|l|ccc|}
\hline House age & Living temp $\left({ }^{\circ} \mathbf{C}\right)$ & SE $\left({ }^{\circ} \mathbf{C}\right)$ & Count of houses \\
\hline Pre-1978 & 21.3 & 0.1 & 260 \\
Post-1978 & 22 & 0.1 & 100 \\
\hline
\end{tabular}

Table 21: Mean living room temperatures by insulation requirements

\subsubsection{Airtightness}

The occupant-reported airtightness was found to have a marginal influence on summer temperatures (French et al 2007a), although the quality of this reported airtightness cannot be quantified. Airtightness was not measured in the HEEP houses due to the expense in both time and money. Instead occupants were asked their opinion on their house's airtightness. Ideally houses should have the ability to control ventilation when needed through opening windows.

\begin{tabular}{|l|ccc|}
\hline Airtightness & Living temp $\left({ }^{\circ} \mathrm{C}\right)$ & $\mathrm{SE}\left({ }^{\circ} \mathrm{C}\right)$ & Count of houses \\
\hline Airtight & 22.3 & 0.1 & 109 \\
Average & 21.8 & 0.1 & 161 \\
Leaky & 21.7 & 0.2 & 49 \\
Draughty & 20.8 & 0.2 & 54 \\
\hline
\end{tabular}

Table 22: Airtightness and living room temperature 


\subsubsection{External shading}

The size of eaves was found to have an influence on the internal temperatures, with houses that have smaller eaves having higher internal temperatures. The eave size was not measured during the installation of the monitoring equipment; instead the eave size was estimated from photographs. Without an objective measurement of the eave size, it is difficult to confirm their importance.

\subsubsection{Other possible influences}

Due to the nature of monitored data it was not possible to examine all the influences on temperatures. Ventilation is thought to be important, but was not able to be measured. Ventilation is difficult to measure due to the influence the weather and occupants have on ventilation rates. Internal gains are another possible influence on temperature, but are also very difficult to measure or estimate.

\subsection{Results from simulations}

A series of changes were carried out with thermal models to explore the relative importance of different design and construction features Chapter 7). These included: increasing and removing eaves; increasing and decreasing infiltration; changing from single to double glazing; halving and doubling the size of the windows; three levels of insulation (none, 1996 Code, and above Code or 'high'); rotating the house to have a north-facing living room (one model was already north); changing internal walls to exposed concrete; changing all floors to exposed concrete; increasing shading from neighbouring trees and houses; and increasing and decreasing ventilation.

As everything is controlled a greater number of features were able to be examined compared to analysis of monitored data. All changes were made to all houses where 
applicable (adding mass by changing the timber floor to concrete was not possible in the one house that already had a concrete slab floor). All changes were made one at a time to see the effect of that one change. Each change was made to the original model of the house as it was built. In further work, it is suggested that combinations of changes should be looked at. The changes to the models that had the biggest effect on increasing the living room temperature were:

- Increasing the glazing area

- Decreasing ventilation

- Removing the eaves

- Increasing insulation.

The most significant decrease in reducing the summer peaks were from:

- Decreasing glazing area

- Increasing usable mass - through either exposed concrete walls or floors

- Increasing ventilation.

Each of these have a basis in both physics and common sense: increasing window size increases solar gains; decreasing ventilation reduces the house's ability to remove heat from the house; increasing thermal insulation increases heat retention; and increasing thermal mass increases temperature stability.

Figure 28 shows the temperature changes in the models over the validated base case (see Section 7.3). See Table 12 for descriptions of the houses. The base case is when the house is modelled as built and run by the occupants. Temperatures were 
generated by SUNREL for the first three weeks of January 2003 in the living room zone. The maximum temperature was calculated for each day and an average maximum found for both the base and altered model. The same was done for the base model. The difference from the base average maximum temperature (y-axis) was then plotted in Figure 28. A positive value means the temperature has increased and a negative value means the temperature has decreased compared to the base. By averaging the differences over three weeks one-off occupant actions or particularly hot or cold days are averaged out. 


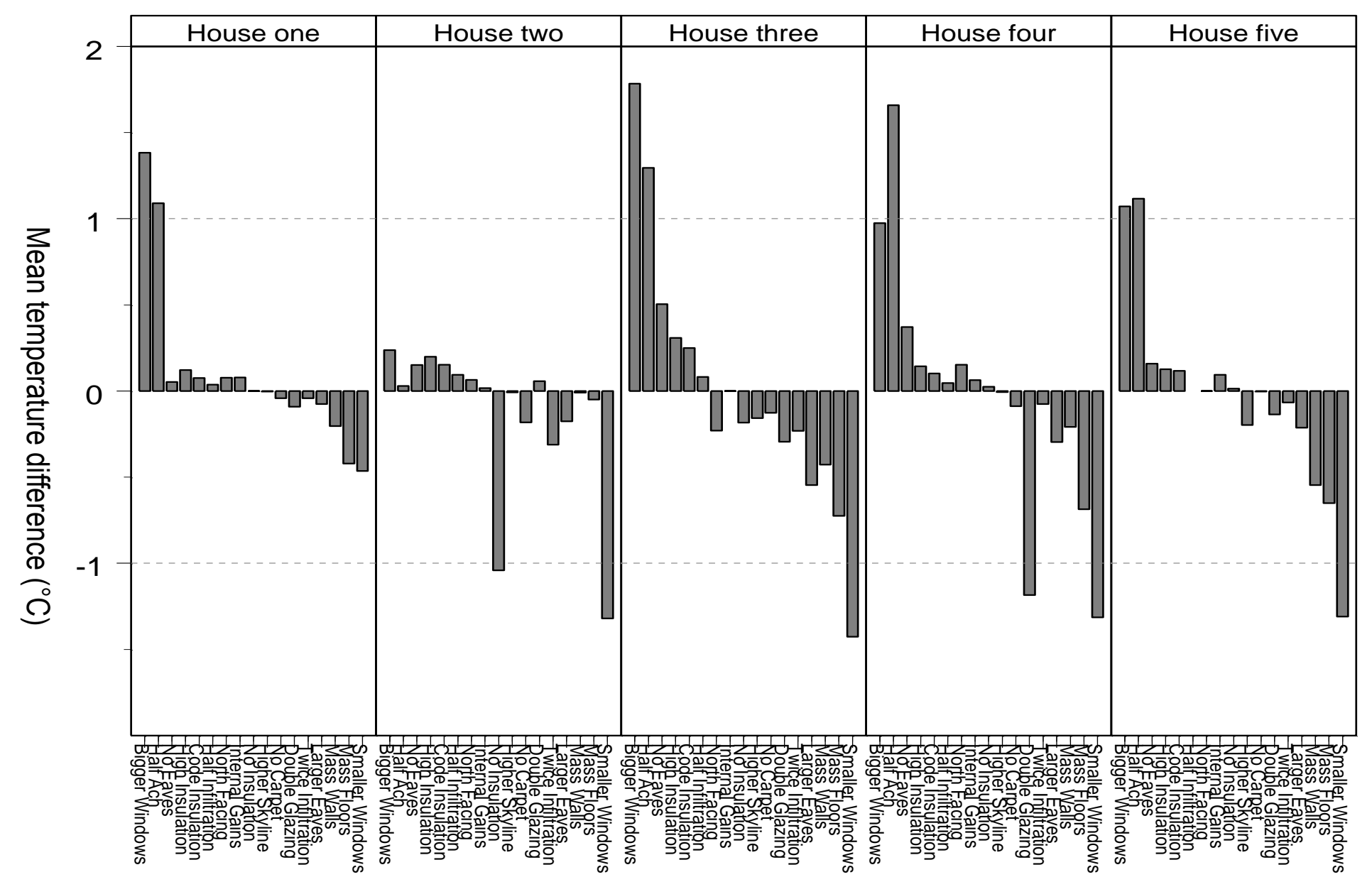

Figure 29: Increasing and decreasing maximum temperatures 


\subsubsection{Glazing area}

Two changes were made to the windows: first they were doubled in size, then halved. To double the size the window height was doubled, and where it was not possible to double height, the length was doubled. In some cases it was not possible to do either, so the windows were then made as big as possible given the size of the wall. To decrease window size the height was halved. Table 23 gives the percentage of window-to-wall area for the base case, and when the window area was increased and decreased.

\begin{tabular}{|l|ccc|}
\hline \multirow{2}{*}{ House number } & \multicolumn{3}{|c|}{$\%$ of walls as windows } \\
& Base & Increased & Decreased \\
\hline One & 12 & 23 & 6 \\
Two & 26 & 53 & 13 \\
Fouree & 23 & 45 & 11 \\
Five & 27 & 39 & 13 \\
& 26 & 43 & 13 \\
\hline
\end{tabular}

Table 23: Window percent of wall area

\subsubsection{Ventilation}

The base case ventilation rate was halved. The base case rate was $40 \mathrm{ac} / \mathrm{h}$ and the reduced amount $20 \mathrm{ac} / \mathrm{h}$.

\subsubsection{External shading}

The base house eaves were increased by doubling the projection and to decrease eave size they were removed. Table 24 gives the average eave projection for each of the models. 


\begin{tabular}{|l|ccc|}
\hline House number & Base & Increased & Decreased \\
\hline One & $0.5 \mathrm{~m}$ & $1 \mathrm{~m}$ & $0 \mathrm{~m}$ \\
Two & $1.6 \mathrm{~m}$ & $3.2 \mathrm{~m}$ & $0 \mathrm{~m}$ \\
Three & $1.0 \mathrm{~m}$ & $2.0 \mathrm{~m}$ & $0 \mathrm{~m}$ \\
Four & $1.2 \mathrm{~m}$ & $2.4 \mathrm{~m}$ & $0 \mathrm{~m}$ \\
Five & $0.6 \mathrm{~m}$ & $1.2 \mathrm{~m}$ & $0 \mathrm{~m}$ \\
\hline
\end{tabular}

Table 24: Average eave projection

\subsubsection{Insulation}

A range of different levels of insulation were tested: none, 1996 Code, and high insulation. Some of the base cases had insulation to start with as shown in Table 25. The first step was modelling the houses with no insulation, and then the different levels were tested in Table 26. Double glazing was also tested separately.

\begin{tabular}{|l|ccc|}
\hline House & Walls & Floor & Ceiling \\
\hline One & None & None & None \\
Two & Aluminium foil & None & Loose fill \\
Three & None & None & Loose fill \\
Four & Fibreglass & None & Fibreglass \\
Five & Fibreglass in latest addition & Latest addition only & Fibreglass in latest addition \\
\hline
\end{tabular}

Table 25: Insulation in base cases 


\begin{tabular}{|l|c|l|l|l|}
\hline \multirow{2}{*}{ Insulation level } & \multicolumn{4}{|l|}{ R-values $\left(\mathbf{m}^{2}{ }^{\circ} \mathbf{C} / \mathbf{W}\right)$ for insulation and glazing } \\
\cline { 2 - 5 } & Glazing & Ceiling & Wall & Floor \\
\hline Code 1996 & 0.15 & 1.9 & 1.5 & 1.0 \\
\hline High insulation & 0.26 & 3.2 & 1.8 & 1.0 \\
\hline
\end{tabular}

Table 26: R-value of insulation for Code and high insulation tests in models

\subsubsection{Thermal mass}

Increasing usable mass was done by two methods; First changing timber floors to 100 $\mathrm{mm}$ concrete and removing all coverings, and where the floor was already concrete the coverings were removed; and secondly by converting all internal walls to $70 \mathrm{~mm}$ thick concrete. All base cases had lightweight uninsulated internal walls. The floor materials for the base cases can be seen in Table 27 and wall materials in Table 28.

\begin{tabular}{|l|cc|}
\hline House & Ground & Upper \\
\hline One & Timber & N/A \\
Two & Concrete & Concrete \\
Three & Timber & N/A \\
Four & Concrete & Timber \\
Five & Concrete & Timber \\
\hline
\end{tabular}

Table 27: Floor material 
Design and construction features that cause new houses in New Zealand to overheat

\begin{tabular}{|l|cc|}
\hline House & Ground & Upper \\
\hline One & Timber-frame/weatherboard & N/A \\
Two & Concrete block & Timber-frame/brick \\
Three & Timber-frame/weatherboard & N/A \\
Four & Concrete block & Timber-frame/weatherboard \\
Five & Timber-frame/brick & Timber-frame/weatherboard \\
\hline
\end{tabular}

Table 28: Wall material 


\section{Discussion on design and construction features causing overheating}

Temperature data analysis has found newer houses are warmer in summer, with many being uncomfortably warm (French et al 2007a). Through monitored temperature data of 397 houses and thermal modelling, it has been possible to determine which features are causing new houses to be warmer. If current construction methods and design trends continue, along with climate change, it is likely New Zealand houses are going to continue to increase in temperature. It is important to understand why newer houses are warmer, to prevent overheating houses being built in the future.

The key features found to cause increased temperatures were over-glazing, lack of ventilation and lack of external shading. By controlling these three parameters a comfortable and sustainable house for future generations can be built. From this work some basic design principles have been developed to prevent overheating in summer. Thermal insulation was also found to increase temperatures during summer.

However, insulation is a requirement in new houses, as it is important for reducing heat losses during winter. The increase in summer temperatures caused by insulation is not considered significant enough to reduce insulation requirements. Overheating should be considered when future upgrades to the insulation requirements in New Zealand occur. Insulation causes the temperature to increase due to warm air being trapped inside the building. This temperature rise can be solved by having satisfactory ventilation to remove the warm air.

Increasing temperatures and overheating in new houses are a concern for many reasons. Occupants will be finding the temperatures reached in new houses 
uncomfortable. The World Health Organisation (WHO) suggests an optimum temperature range of $18^{\circ} \mathrm{C}$ to $25^{\circ} \mathrm{C}$ (WHO 2003). Many of the new houses in the sample of monitored houses are experiencing temperatures above the optimum temperature range, and above what is considered comfortable. During summer an average 1990s house in New Zealand spends $40 \%$ of the time between 4 pm and 6 pm above $25^{\circ} \mathrm{C}$.

Climate is the largest single influence on summer indoor temperature. Climate change is therefore an issue for designing houses that will be comfortable in the future. Any ambient temperature increase will increase indoor temperatures. New Zealand's climate is expected on average to be $3^{\circ} \mathrm{C}$ warmer by the 2080s (Ministry for the Environment 2008), which would increase the indoor temperature by $2.4^{\circ} \mathrm{C}$ on average (French et al 2007a).

In previous New Zealand research only $4 \%$ of the houses had the ability to be actively cooled and little evidence of cooling was found (Isaacs et al 2006). Now in a survey conducted in 2007 almost $20 \%$ of New Zealand houses have the ability to cool through reverse cycle heat pumps and $60 \%$ of households are choosing to cool (French 2008). Heat pumps may solve the problem of an overheating house, but they use electricity when a good design may have prevented the house from overheating. There is the danger of occupants becoming reliant on heat pumps for summer cooling, with the resulting higher electricity use forming a positive loop into the mechanism of climate change.

Due to the increasing demand for electricity and the constant need for upgrading the grid, the cost of electricity is rising in New Zealand. If energy prices continue to rise 
people may not be able to afford to cool (just as some people currently cannot afford to heat). If we design and build houses that require cooling, we are creating houses whose occupants may not be able to maintain a comfortable temperature.

To prevent new houses being built that require electricity to be comfortable, the house features were determined that are causing the temperature increase. To do so the following steps were taken.

To understand what features are changing in new houses, house design was examined through literature and the HEEP database. The database holds house plans and house audit information on 397 houses in New Zealand. Some of the key changes in new houses over time include: increased glazing areas; reduced eaves and verandas; increasingly airtight construction; suspended timber floor to concrete slabs; and increased insulation levels. All of these features were examined to see their influence on increasing temperatures.

To ensure the correct features of the houses were examined a literature review was undertaken. The review was completed to understand which building features are considered to be most influential on temperatures, allowing these features to be examined. Unfortunately very little of the literature available was written for New Zealand. The available literature focused on how to decrease temperatures in very hot climates, such as passive cooling through courtyards. From this review several features were identified as likely to be influential on indoor temperatures. The most important were: ventilation, area of glazing, shading, site selection, insulation, internal gains and thermal mass. These changes were examined to determine their influence on increasing temperatures. 
With the changes in house design understood, and the features that affect temperature known, it was possible to examine their influence on increasing temperatures. Through the monitored temperature data, real houses were able to be examined to determine the influences of features. No other study found has been able to look at such a representative sample of real houses. There are limitations when dealing with monitored data, such as limitations on what is known and controlled. This was overcome by using five validated thermal models to allow one feature at a time to be modified. The models were validated against the monitored house data to ensure the results are relevant to New Zealand houses.

The process of analysing monitored houses and using validated models allows the basic design principles described to be presented with confidence.

\subsection{Design principles}

To have a comfortable house without active cooling, certain features should be considered at the design stage. An overheating house could be difficult to 'fix' once built. This work indicates that the key areas which need to be considered at the design stage are the glazing area, the ability to control ventilation and exterior shading. A common sense approach can be taken for designing a sustainable home.

The area of the glazing was found to be the most influential feature on indoor temperatures. It is important there is sufficient daylight in a building, but too much glazing has negative effects on comfort in summer and winter. In summer the solar gains through the glazing will increase the indoor temperature, and if occupants are in direct sunlight the high radiant heat will cause discomfort. 
During winter the high heat losses through the glazing make a building harder to heat. There are a range of tools to calculate if there is sufficient daylight in a space (e.g. Elkink 2008). Designers need to think carefully before having more glazing than is necessary. Further work is needed to know what an acceptable range of window-towall proportions is. It is expected to be dependent on the house, in particular the amount of mass, external shading, climate and orientation.

Ventilation is important to remove heat build-up within the house. Heat build-up occurs from solar and internal gains (appliances, occupants etc) being trapped inside the house. Almost any building has the potential to overheat without adequate ventilation. Good cross-ventilation by opening windows on both sides of the house will provide air movement, removing heat from the house. Ideally the windows will be designed so occupants are able to open them safely, without causing a security risk or letting in unwanted noise, and in a location and of a type that is easy to use.

Louvers and bi-fold windows are ideal for opening large areas but they need to be practical. It is important a large area can open, rather than just a small area on a security latch. However having windows opening on a security latch while away from the house allows some extra ventilation during the warmer months. Passive vents can also be used to increase background ventilation, but are not sufficient as the only method of ventilation. Ceiling or room fans can be used for increasing air movement. Forced air ventilation systems are also an option for houses. Little research has been done in New Zealand, but they are reported to be useful in the evenings and overnight for reducing the indoor temperature through night cooling. It is important to consider the practicality and ease of use for all methods. 
External shading is the third feature to consider. Shading reduces the amount of solar gains that will enter the house. The importance of shading reduces as the amount of glazing reduces. Internal shading (through blinds, curtains etc), are not as effective at reducing overheating due to the heat still being able to enter the space. They do help protect occupants from direct sunlight, which can cause discomfort. As with the glazing area it is important to determine how the sun is going enter the building to ensure there is sufficient daylight.

The amount of glazing, ventilation and shading are considered the most influential features for overheating in summer from this work. From the results discussed in Chapter 9, an indication of what house features are causing new houses to increase in temperature during the summer are given. However there are other features which have been found to help prevent overheating in the thermal modelling. Many of the houses modelled were lightweight and when extra thermal mass was added either in the floors (without carpet) or the internal walls, the indoor temperature was found to decrease. Combinations of influences were not looked at in this work. This is an area where further work could be beneficial.

Existing houses that are having overheating problems have limited options. To increase air flow ceiling fans or room fans could be used, or changing some fixed windows to opening. To lessen solar gains the easiest way is to externally shade windows that are letting in large amounts of sunshine. Exposing thermal mass could be an option depending on the materials in the house, or the addition of mass e.g. adding a high mass internal feature wall. Changes to occupant behaviour could help e.g. leaving more windows open with security latches, opening windows earlier and 
leaving windows open on both sides of the house. It is important to consider the results of this work to achieve significant reductions in temperatures.

To prevent overheating government regulation is an option, although with practical design this would not be necessary. The most effective ways of regulating would be limiting the amount of glazing and placing a lower limit on openings.

The new requirements for energy-efficient housing ( $\mathrm{DBH} 2007)$ discourage more than $30 \%$ of the wall area being glazed. If more than this wall area is glazed, it becomes harder for the house to pass the thermal requirements. This rule has been designed for preventing heat losses in winter, rather than decreasing the solar gains in summer. However designers will need to consider their design carefully before exceeding the $30 \%$ rule; hopefully this should also reduce overheating. 


\section{References}

ASHRAE. 2004. 'ASHRAE Standard 55-2004.Thermal Environmental Conditions for Human Occupancy'. ASHRAE, Atlanta, USA.

ASHRAE. 2005. 'ASHRAE Handbook - 2005 Fundamentals, SI Edition'. ASHRAE, Atlanta, USA.

Auliciems A and Szokolay S. 1997. Thermal Comfort. PLEA Note 3: Passive and Low Energy Architecture International in association with Department of Architecture, the University of Queensland, Brisbane, Australia.

Australian Bureau of Statistics. 2008. 'Feature Article 3: Changing Water and Energy Use in Perth Homes'. 1367.5 - Western Australian Statistical Indicators (June 2007). www.abs.gov.au/AUSSTATS/abs@.nsf/7d12b0f6763c78caca257061001cc588/dfb739 90a3566e15ca25725e001a4d51!OpenDocument accessed 21 February 2008.

Baker N and Standeven,K. 1996. 'Thermal Comfort for Free-running Buildings'. Energy and Buildings 23:175-182.

Bassett M. 1992. House Airtightness Variation with Age. 10th International Passive and Low Energy Architecture (PLEA) Conference. Auckland, New Zealand.

Brager GS and de Dear RJ. 1998. 'Thermal Adaptation in the Built Environment: A Literature Review'. Energy and Buildings 27(1): 83-96. 
Brager GS and de Dear R. 2001. 'Climate, Comfort \& Natural Ventilation: A New Adaptive Comfort Standard for ASHRAE Standard 55'. In Proceedings of Moving Thermal Comfort Standards Into the 21st Century. 5-8 April, 2001, Windsor, UK.

BRANZ. 2005. Smart Building Tips. BRANZ calendar, Judgeford, New Zealand.

Buckett NR. 2007. 'National Impacts of the Widespread Adoption of Heat Pumps in New Zealand'. BRANZ Study Report 169. BRANZ Ltd, Judgeford, New Zealand.

Bureau of Meteorology. 2008. Average Daily Sunshine Hours Maps. .www.bom.gov.au/cgi-bin/climate/cgi bin scripts/sunshine-hrs.cgi accessed May 2008.

Camilleri MT. 2000. 'Implications of Climate Change for the Construction Sector: Houses'. BRANZ Study Report 94. BRANZ Ltd, Judgeford, New Zealand.

Chiras D. 2002. The Solar House - Passive Heating and Cooling. Chelsea Green Publishing Company, Vermont, USA.

Clark SJ, Jones M and Page IC. 2005, 'New Zealand 2005 House Condition Survey’. BRANZ Study Report 142. BRANZ Ltd, Judgeford, New Zealand.

Dang H, Tamayo J and Wilkinson D. 2007. New Zealand Energy in Brief. Ministry of Economic Development, Wellington, New Zealand. 
de Dear R. 2004. 'Thermal Comfort in Practice'. Indoor Air 14 (Suppl 7): 32-39.

Department of Building and Housing (DBH). 2007. Compliance Document for New Zealand Building Code - Clause H1 - Energy Efficiency - Third Edition. DBH, Wellington, New Zealand.

Deru M, Judkoff R and Torcellini P. 2002. SUNREL - Technical Reference Manual. National Renewable Energy Laboratory (NREL), Colorado, USA.

Donn M and Thomas G. 2001. Designing Comfortable Homes - Guidelines on the Use of Glass, Mass and Insulation for Energy Efficiency. Cement \& Concrete Association of New Zealand (CCANZ), Wellington, New Zealand.

Elkink A. 2008. Passive Design. Level Sustainable Building Series, BRANZ Ltd, Judgeford, New Zealand.

Energy Efficiency and Conservation Authority (EECA). 2007. New Zealand Energy Efficiency and Conservation Strategy - Making It Happen (NZEECS). www.eeca.govt.nz/about/national-strategy/nzeecs-index.html accessed 30 September 2007.

Erbs DG, Klein SA and Duffie JA. 1982. 'Estimation of the Diffuse Radiation Fraction for Hourly, Daily and Monthly Average Global Radiation'. Solar Energy 28:293-302

Fanger PO. 1970. Thermal Comfort. McGraw-Hill, New York, USA. 
Fowler M and van de Voort R. 1983. The New Zealand House, Lansdowne Press, Auckland.

French LJ, Camilleri MJ, Isaacs NP and Pollard AR. 2006. 'Exploration of Summer Temperatures in New Zealand Houses and the Temperature Drivers'. In Proceedings of Getting Them Right. 27-30 April 2006, Windsor, UK.

French LJ, Camilleri MJ and Isaacs NP. 2007a. Influences on Summer Indoor Temperatures in a Representative Sample of New Zealand Houses. $\mathrm{XXXV}^{\text {th }}$ International Association of Housing Science (IAHS) World Congress on Housing Science, 4-6 September 2007, Melbourne, Australia.

French LJ, Camilleri MJ, Isaacs NP and Pollard AR. 2007b. 'Temperatures and Heating Energy in New Zealand Houses from a Nationally Representative Study HEEP'. Energy and Buildings 39(7): 770-738.

French LJ. 2008. 'Active Cooling and Heat Pump Use in New Zealand - Survey Results'. BRANZ Study Report 186. BRANZ Ltd, Judgeford, New Zealand.

Garde F, Mara T, Luret AP, Boyer H and Celaire. R. 2001. 'Bringing Simulation to Implementation: Presentation of a Global Approach in the Design of Passive Solar Buildings Under Humid Tropical Climates'. Solar Energy 71(2): 109-120.

Hacker J, Holmes M, Belcher S and Davies G. 2005. Climate Change and the Indoor Environment: Impacts and Adaptation. CIBSE TM36:2005. The Chartered Institution of Buildings Services Engineers, London, UK. 
Hastings R and Wall M. 2007 Sustainable Solar Housing - Volume 1 - Strategies and Solutions. Earthscan, London, UK.

Humphreys MA. 1978. 'Outdoor Temperatures and Comfort Indoors'. Building Research and Practice (March/April).

Humphreys MA and Nicol JF. 1998. 'Understanding the Adaptive Approach to Thermal Comfort'. ASHRAE Transactions 104(1): 991-1004.

Innova. 2007. Thermal Comfort Booklet. www.lumasense.dk/Booklets.60.0.html accessed November 2007.

International Standard Organization. 2005. ISO 7730:2005 Ergonomics of the Thermal Environment - Analytical Determination and Interpretation of Thermal Comfort Using Calculation of the PMV and PPD Indices and Local Thermal Comfort Criteria. ISO, Geneva, Switzerland.

Isaacs NP. 1993. Thermal Efficiency in New Zealand Buildings: A Historical Overview. Centre for the Building Performance Research, Victoria University of Wellington, New Zealand.

Isaacs NP. 1999. 'Performance Based Building Energy Efficiency Code'. In Proceedings Global Building Model in the Next Millennium Conference. 12-15 April 1999, Melbourne, Australia. (BRANZ Conference Paper 63: 108-118). 
Isaacs NP, Amitrano LJ, Camilleri MJ, French LJ, Pollard AR, Saville-Smith K, Fraser R and Rossouw P. 2004. 'Energy Use in New Zealand Households: Report on the Year 8 Analysis for the Household Energy End-use Project (HEEP)'. BRANZ Study Report 133. BRANZ Ltd, Judgeford, New Zealand.

Isaacs NP, Camilleri MJ, French LJ, Pollard AR, Saville-Smith K, Fraser R, Rossouw P and Jowett J. 2006. 'Energy Use in New Zealand Households: Report on the Year 10 Analysis for the Household Energy End-use Project (HEEP)'. BRANZ Study Report 155. BRANZ Ltd, Judgeford, New Zealand.

Jaques RA. 2000. 'Summertime Overheating in New Zealand Houses - Influences, Risks and Mitigation Strategies'. BRANZ Study Report 89, BRANZ Ltd, Judgeford, New Zealand.

Keating EC. 1978. Average Degree-Day Tables Selected New Zealand Stations. Ministry of Transport and New Zealand Meteorological Service, Wellington, New Zealand.

Lane J. 1986. Energy-Efficient Housing Design - A Combined Approach - The Earth Sheltered/Super Insulated/Passive Solar House. Van Nostrand Reinhold Company, New York, USA.

Lincoln College. 1975. The Age of Houses Illustrated. Farm Management and Rural Valuation Department, Lincoln College, Lincoln, New Zealand. 
Maxwell EL. 1987. A Quasi-physical Model for Converting Hourly Global Horizontal to Direct Normal Isolation. Report SERI/TR-215-3087, Solar Energy Research Institute, Golden, USA.

McIntyre DA. 1980. Indoor Climate. Applied Science Publishers Ltd, Essex, England.

Meteorological Service of New Zealand Ltd (MetService). 2006. The Climate of New Zealand. www.metservice.co.nz/default/index.php?alias=learningcentre accessed 9 February 2006.

Ministry for the Environment. 2008. A Changing Climate. www.mfe.govt.nz/publications/climate/a-changing-climate-nov04/a-changingclimate.pdf accessed 15 May 2008.

Ministry of Transport. 1983. Summaries of Climatological Observations to 1980: Stations Represented are in New Zealand, Including its Outlying Islands, the Ross Dependency (Antarctica) and Territories of the South-west Pacific. New Zealand Meteorological Service, Wellington, New Zealand.

Mole C (Assoc Ed). 2008. 'Reaching 90\% Renewables Target A Breeze: Parker'. New Zealand Energy \& Environment Business Week (5)1: 16 April.

Muncey RWR. 1979. Heat Transfer Calculations for Buildings. London, Applied Science Publishers Ltd, London, UK. 
National Institute of Water and Atmospheric Research (NIWA). 2007. Climate Data. www.niwa.cri.nz/edu/resources/climate accessed August 2007.

Nicholas JV and White DR. 2001. Traceable Temperatures - An Introduction to Temperature Measurement and Calibration. Second Edition, Measurement Standards Laboratory of New Zealand, John Wiley \& Sons, Ltd, London, UK.

Nicol JF,and Humphreys MA. 2002. 'Adaptive Thermal Comfort and Sustainable Thermal Standards for Buildings'. Energy and Buildings 34(6): 563-572.

Orme M and Palmer M. 2003. Control of Overheating in Future Housing - Design Guidance for Low Energy Strategies. Faber Maunsell Ltd, London, UK.

Oseland NA and Humphreys MA. 1994. Trends in Thermal Comfort Research. BRE, Watford, UK.

Page I. 2005 ‘BRANZ Building Materials Survey’. BUILD 90 (October/November): 65.

Pearson D. 1998. 'The New Natural House Book - Creating a Healthy, Harmonious and Ecologically Sound Home. Simon \& Schuster, New York, USA.

Penny AC. 2003. Climate Database (CLIDB) User's Manual 5th Edition. NIWA, Wellington, New Zealand. www.niwascience.co.nz/services/clidb/ accessed 9 January 2006. 
Perez R, Aguiar R, Collares-Pereira M, Dumortier D, Estrada-Cajigal V, Gueymard C, Ineichen P, Littlefair P, Lund H, Michalsky J, Olselth JA, Renne D, Rymes M, Skartveit A, Vignol F, Zelenka A. 2001. 'Solar Resource Assessment: A Review'. Published in Solar Energy - The State of the Art - ISES Position Papers. Edited by Jeffrey Gordon. James \& James Ltd, London, UK.

Quotable Value NZ. 2007. Property Information. www.qv.co.nz accessed August, September and October 2007.

Robinson H, Cosgrove L and Powell F. 1957. Thermal Resistance of Airspaces and Fibrous Insulations Bounded by Reflective Surfaces. Report No. 151, US Dept Commerce, Building Materials and Structures.

Rohles FH Jn. 2007. 'Temperature \& Temperament - A Psychologist Looks at Comfort'. ASHRAE Journal 49(2): 14-22 (February).

Shaw P. 1997. A History of New Zealand Architecture. Hodder Moa Beckett, Auckland, New Zealand.

Sherman MH and Grimsrud DT. 1980. 'Infiltration-pressurization Correlation: Simplified Physical Modelling'. ASHRAE Transactions 86(2): 778.

SmarterHomes. 2008. Orientation. www.smarterhomes.org.nz/design/orientation/ accessed March 2008. 
Smith N. 2007. Thermal Comfort - A Pilot Field Study of Thermal Comfort in New Zealand Households. A research report submitted for Building Science Honours, Victoria University of Wellington, New Zealand.

Standards New Zealand. 1999. NZS 3604:1999 - Timber framed buildings. SNZ, Wellington, New Zealand.

Standards New Zealand. 2003. NZS PAS 4244:2003 - Insulation of LightweightFramed and Solid-Timber Houses'. SNZ, Wellington, New Zealand.

Standards New Zealand. 2004 NZS 4218:2004 Energy Efficiency - Small Building Envelope. SNZ, Wellington, New Zealand.

Standards New Zealand. 2006. NZS 4214: 2006 - Methods of Determining the Total Thermal Resistance of Parts of Buildings. SNZ, Wellington, New Zealand.

Statistics New Zealand. 2005. Profile of New Zealand. Accessed electronically www.stats.govt.nz/quick-facts/default.htm 3 March 2006.

Stevens DG. 1982. 'Recommended Passive Solar Process'. New Zealand Architect $(4): 26: 29$

Stoecklein A and Bassett M. 2000. ALF3 - The Annual Loss Factor Method - A Design Tool for Energy-efficient Houses - Calculation Manual to be Used in Conjunction with the BRANZ House Insulation Guide. Third Edition. BRANZ Ltd, Judgeford, New Zealand. 
Tims G. 2007. House Insulation Guide'. Third Edition, BRANZ Ltd, Judgeford, New Zealand.

Transpower. 2008. Welcome to Grid New Zealand. www.gridnewzealand.co.nz/ accessed 10 May 2008.

University of Sydney. 2008. Guidelines for Indoor Thermal Comfort and Ventilation. www.usyd.edu.au/ohs/policies/ohs/IndoorThermalComfort.shtml accessed 20 May 2008.

World Health Organization (WHO). 2003. Heat-waves: Impacts and Responses. WHO Briefing Note for the Fifty-third Session of the WHO Regional Committee for Europe, Vienna, Austria.

Yoo O. 1998. A Field-study of Thermal Comfort in Wellington Houses. A research report submitted to the Department of Architecture to meet the requirements of the transition course, Victoria University of Wellington, Wellington. 


\section{Appendix A: Temperature measurement}

The HEEP monitoring used two types of temperature loggers. The BTL (shown in Figure 30) is a low cost, compact $(90 \times 60 \times 25 \mathrm{~mm})$ temperature logger designed at BRANZ Ltd. Instantaneous temperature readings are made at one of the pre-set logging intervals which include one, two, five, 10 and 15 minute intervals. The memory of the logger allows for the storage of approximately 200 days of 10 minute data.

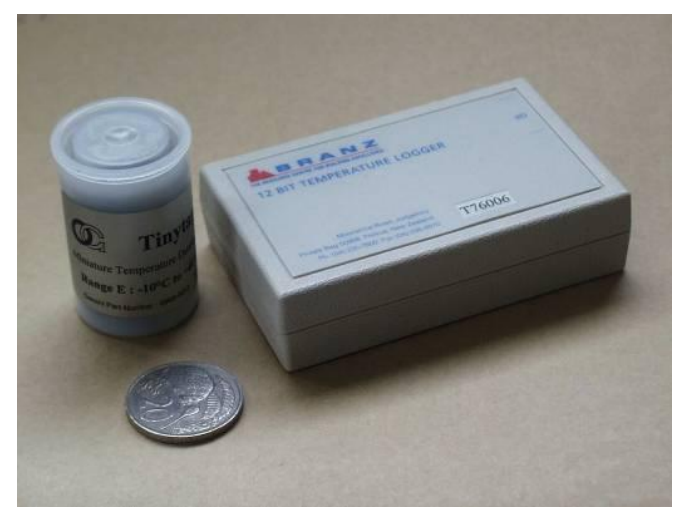

Figure 30: A BRANZ temperature

logger (right) with a Tiny-tag

temperature logger

The Tiny-tag is manufactured by Gemini Data Loggers in the UK and is a compact logger being enclosed in a standard $35 \mathrm{~mm}$ film canister (54 x $32 \mathrm{~mm}$ diameter). A picture of a Tiny-tag logger is shown in Figure 30. The Tiny-tag loggers record an instantaneous temperature measurement at an adjustable recording interval of between one second and 10 days. The General Range Tiny-tag has a temperature range of $-40^{\circ} \mathrm{C}$ to $75^{\circ} \mathrm{C}$. 


\section{What the BRANZ temperature loggers monitor}

Several small experiments were carried out to determine how radiant heat affects the logger readings. The proportion of each radiant and air temperature the logger measures depends on the conditions in the room e.g. air flow, distance to a radiant heat source and power of radiant heat source. Radiant heat sources include humans, sunlight and radiant heaters.

For this work the temperature measurements from HEEP are being used to determine occupant comfort in the houses, in particular looking at overheating in the summer months. Both radiant heat and air temperature affect the comfort of the occupant, therefore the two temperatures could be measured separately. However people feel both radiant and air temperature together. The BTL's measure the temperature the occupants feel by measuring both radiant and air temperature together. We do not know, or have any control over, where the occupants are in the space and how they are affected by high amounts of radiant heat. For example if the occupants are sitting in a window with sun shining on them they will receive radiant heat. This will not be picked up in measurements as the loggers are placed out of the sun and away from heat sources. Air flow should increase in summer reducing the effect of radiant heat on the occupants and the loggers. The higher the air flow the less effect radiant heat has. There is also a range of airtightness levels found in the houses. 
According to Dr Rod White ${ }^{19}$ from IRL, if you put a human on a shelf they would feel the same temperature as a BTL will record on the same shelf. What temperature is measured depends on the colour and reflectivity of the logger. A black logger would absorb most of the radiant heat, while a white logger would reflect radiant heat. How much depends on clothing and skin colour. For humans it depends on skin colour and clothing.

Several experiments were conducted to see the influence radiant head has on the logger reading. Heat transfer needed to be understood to conduct the experiments.

\section{Understanding heat transfer}

There are three types of heat flow: radiation, conduction and convection. The type and strength of the heat flows in a space affects the comfort of the occupants. Heat flow is always driven by a temperature difference from the higher temperature region to the lower temperature region.

Thermal radiation is energy in the form of electromagnetic waves and covers the spectrum through radio waves, infrared, light, ultraviolet and on through $\mathrm{x}$-rays if the object is hot enough. All matter with a temperature above absolute 0 emits electromagnetic radiation and generally in large quantities. Thermal radiation does not need a physical medium for the transfer of heat and is most efficient in a vacuum. The total emissivity is a quantity that characterises the ability of an object to emit radiation and has a value between 0 and 1 . When the emissivity is 1 the object is said to be a

19 Rod White, Personal communication 24 August 2006, at Industrial Research Limited (IRL), Gracefield, Lower Hutt, New Zealand. 
blackbody. Objects with dark rough surfaces have a higher emissivity than those with shiny smooth surfaces. Radiation exchange will depend on the mean temperature of the surround surfaces or on the presence of a strong mono-directional radiation source e.g. the sun (Auliciems and Szokolay 1997).

The more air movement there is the greater the influence air temperature has on the sensor. The higher the air movement the less important the mean radiant temperature is to the sensor.

At room temperature $(\sim 300 \mathrm{~K})$, all objects including the human body emit radiation at a rate of about $470 \mathrm{Wm}^{-2}$. The reason we are not normally aware of this high rate of loss is that all of our surroundings are also emitting at approximately the same rate. So, on balance, we absorb almost as much as we emit. However if we go outside on a clear night we cool down quickly because of the radiation emitted into space (Nicholas and White 2001).

Air temperature is the temperature of the air without any influences from radiant heat sources, it is also known as the dry-bulb temperature. Auliciems and Szokolay (1997) conclude this temperature is the most important measurement in determining comfort. But to measure importance of discomfort or stress other environmental factors such as $\mathrm{RH}$, radiation and air movement need to be known.

A dressed human can be considered to be 0.9 to 0.95 as can a standard BTL. Although not all the radiant heat will be reflected 0.03 is considered good, and if the loggers are affected by radiant heat it should still be seen. 
Objects have three basic optical properties - emissivity, reflectivity and transmissivity - since any light falling on a surface must be absorbed, reflected or transmitted. For any object, the capacity to absorb (absorptivity) is the same as the capacity to emit (emissivity). If not we could find situations where heat would flow from cooler temperatures to hotter temperatures, in contradiction to the basic laws of thermodynamics (Nicholas and White 2005)

Reflectivity + emissivity + transmissivity $=1$

\section{Testing BRANZ temperature loggers}

A set of tests were completed to determine how the BTLs are affected by radiant heat sources. Six BTLs were selected for the experiments; three were wrapped in reflective foil.

\section{Testing the emissivity of foil}

The foil used to wrap the loggers and reflect radiant heat was tested in the heat flow meter to measure the emissivity. This gives a measure of how much radiant heat is reflected by the wrapped loggers, and how much is absorbed and hence measured by the logger. 


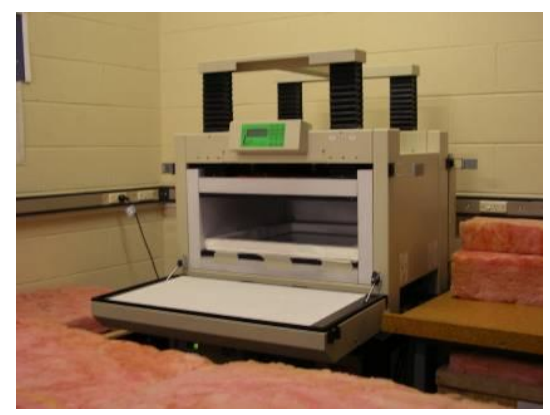

Figure 31: Heat flow meter testing the emissivity of foil

Figure 31 shows the heat flow meter with the foil on the lower plate. The polystyrene around the edge creates an air gap between the upper plate of the heat flow meter and the foil on the lower plate. When the heat flow meter is running the upper plate lowers to touch the polystyrene. The measured R-value from the heat flow meter is $1.095 \mathrm{~m}^{2} \mathrm{~K} / \mathrm{W}$. The emissivity taken from Robinson et al (1957) for an R-value of 1.1 at $23^{\circ} \mathrm{C}$ with a $40 \mathrm{~mm}$ air gap is $0.03 \pm 0.01^{20}$ - this is considered very good.

The foil used for this work is opaque, so therefore the transmissivity is 0 . A perfect reflector will have emissivity of 0 and reflectivity of 1 . A blackbody will have reflectivity of 0 and emissivity of 1 . For these experiments we therefore want the emissivity to be as close to 0 as possible.

20 Ian Cox-Smith and Sheng-Huei (Huey) Huang, Personal communication and assistance, 27 September 2006, BRANZ Ltd, Judgeford, New Zealand. 


\section{Radiant heat source}

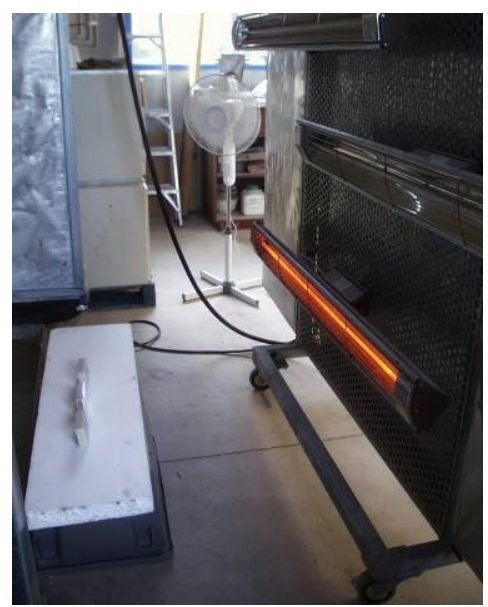

Figure 32: Loggers and radiant heaters

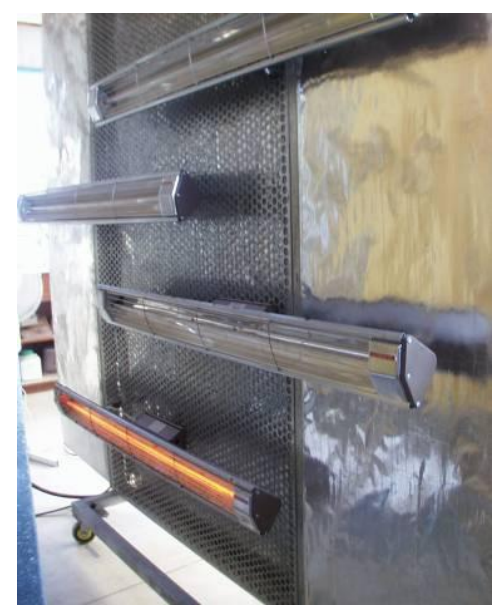

Figure 33: Radiant heaters

The heat-rain rig at BRANZ was used to control radiant heat (Figure 32 and Figure 33). This consists of four $2 \mathrm{~kW}$ bar heaters enclosed in a reflective box. The heaters are controlled by a program which allows them to be cycled on and off. The loggers sitting in front of a radiant heater can be seen in Figure 32. The loggers are insulated from the table by polystyrene. The four heaters can be seen in Figure 33; only one heater was used during the tests as this was considered powerful enough.

Figure 34 and Figure 35 show the temperatures recorded by the two standard loggers and one foil wrapped logger in front of the radiant heat source. The heater is set on a 30 minute cycle, and one 30 minute period of the heater being on is shown in Figure 34. Figure 35 shows three cycles of 30 minutes on and 30 minutes off. The third cycle shown is when the air movement was increased by a portable fan; before this the air movement was little. The temperature of the foil wrapped logger increases by $5^{\circ} \mathrm{C}$, whereas the standard loggers increase by $30^{\circ} \mathrm{C}$ during the 30 minutes of having the 
heater on. During the experiments the 'door' of the heat-rain rig was left open as shown in the pictures.

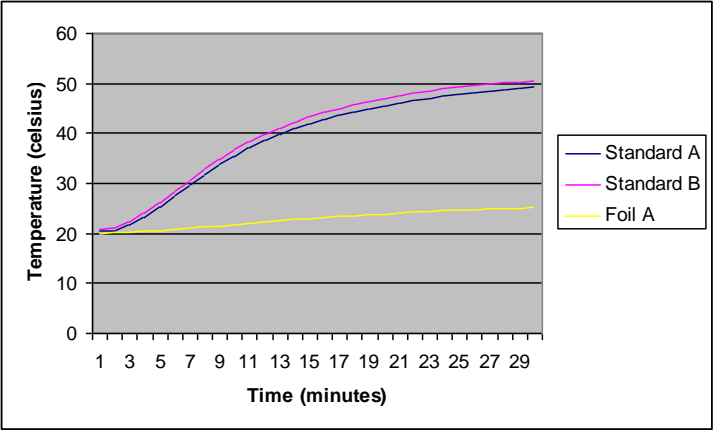

Figure 34: Temperature measurement during 30 minutes of the heater on

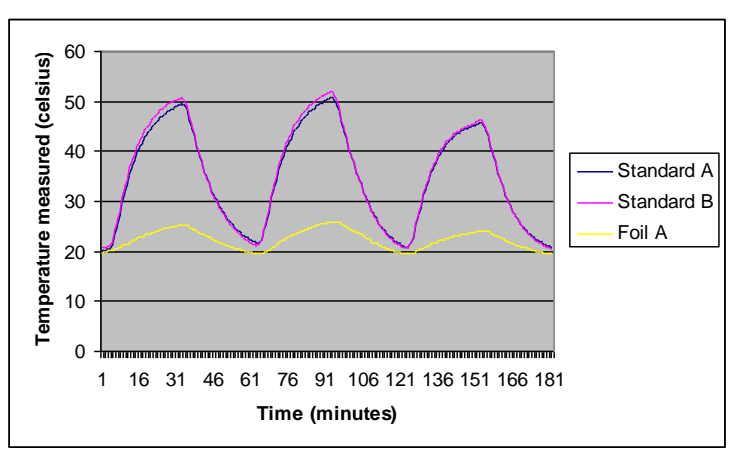

Figure 35: Temperature measurements during three cycles of the heater on

Figure 34 and Figure 35 show temperatures measured by the loggers are affected by radiant heat and air flow. It is not possible to calculate a ratio of radiant-to-air temperature, as it depends on the radiant heat source strength (power and distance) and air flow. The loggers are strongly affected by radiant heat, but placement of loggers in houses minimises this. 


\section{Appendix B: House plan}

The following house plans are drawn as modelled in SUNREL. The house is divided into zones. In many of these zones there will be internal walls that are not shown on the plans, but are modelled. The plans are not to scale. 
House One $-69 \mathrm{~m}^{2}$

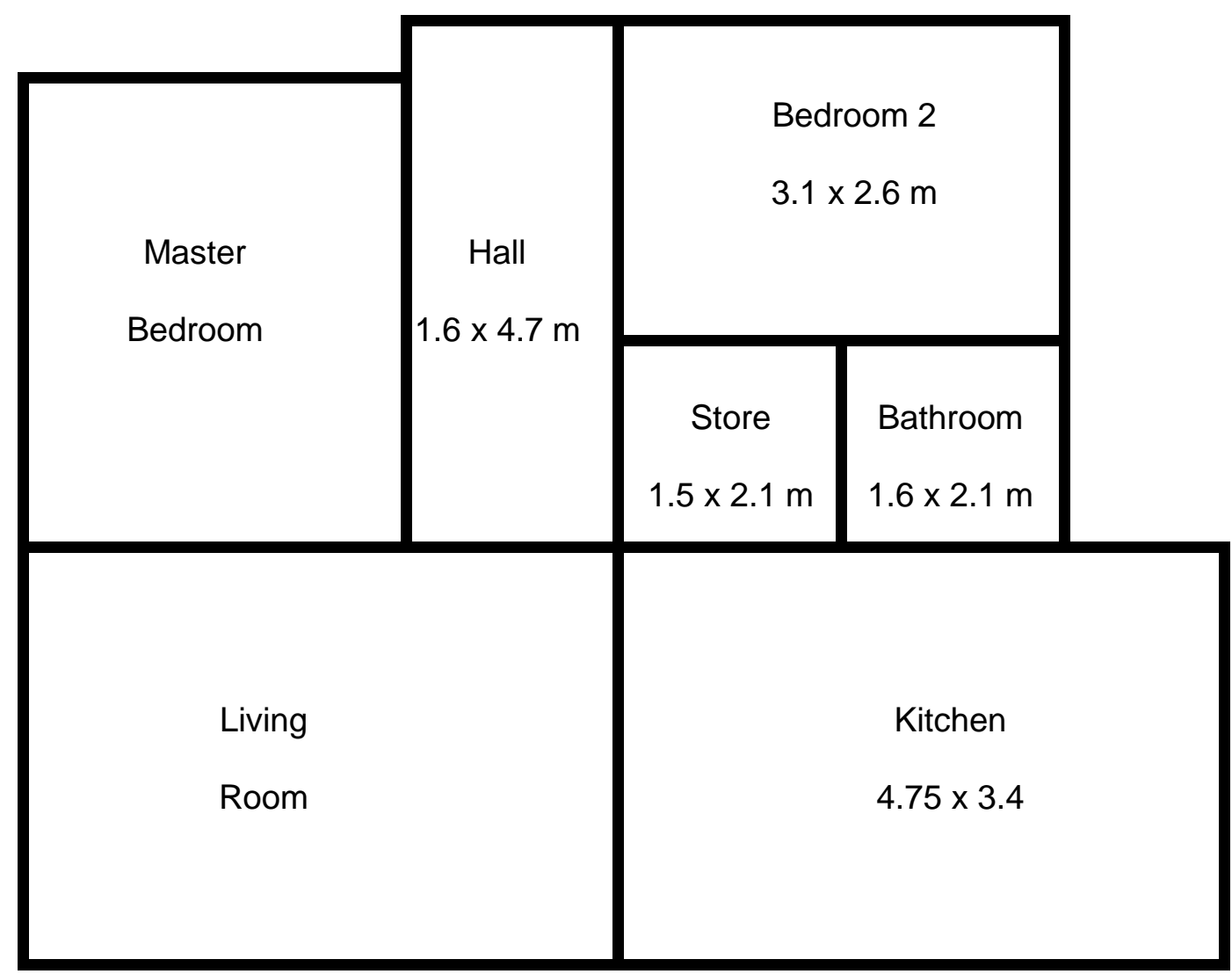

Level One

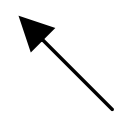

$\mathrm{N}$

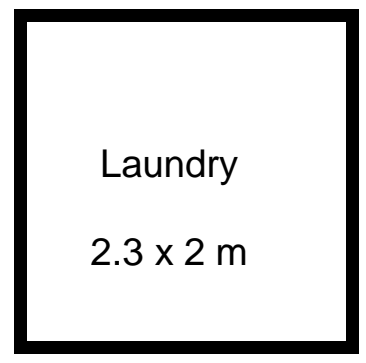

Ground Level 
House Two $-278 \mathrm{~m}^{2}$

First level

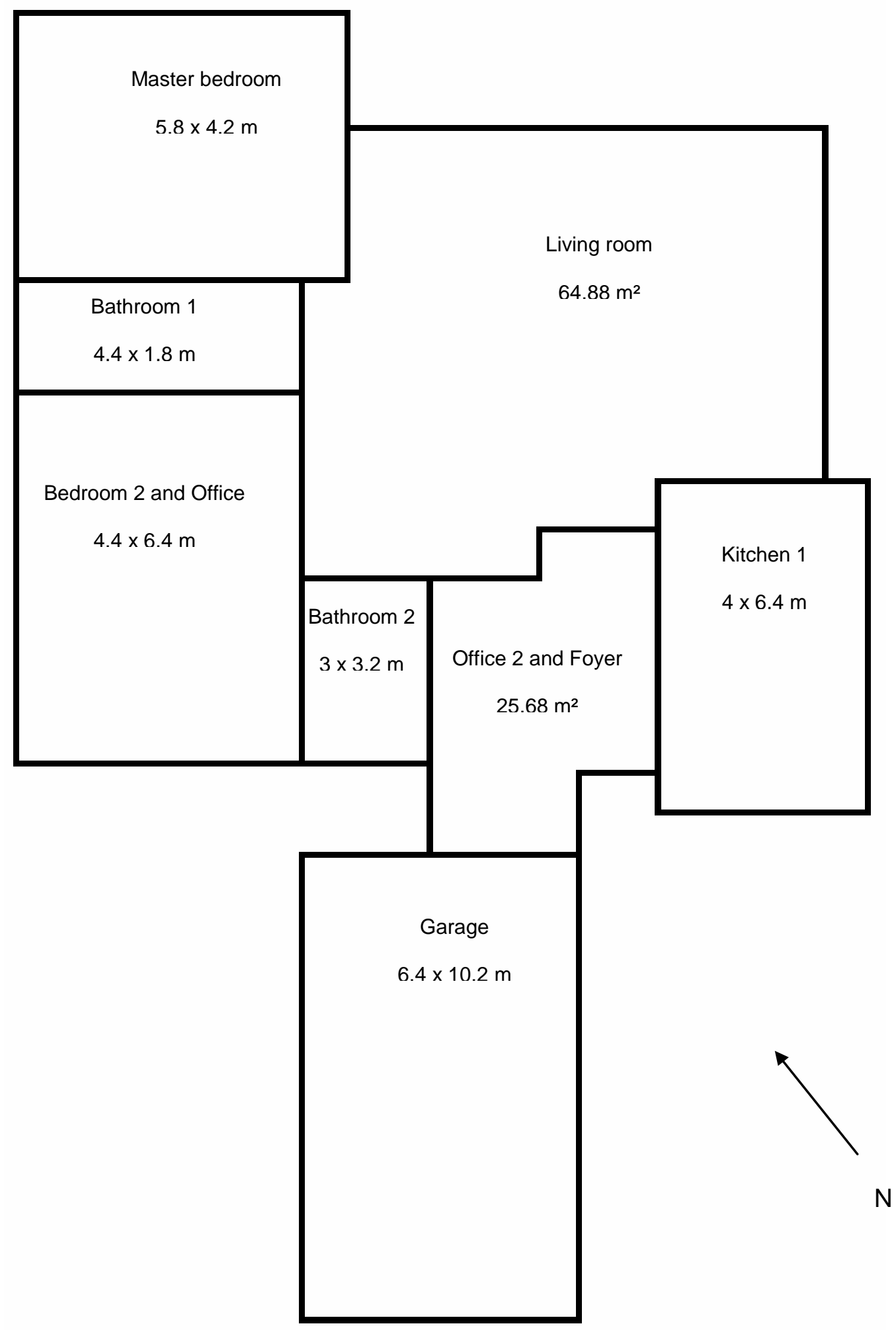




\section{Ground level}

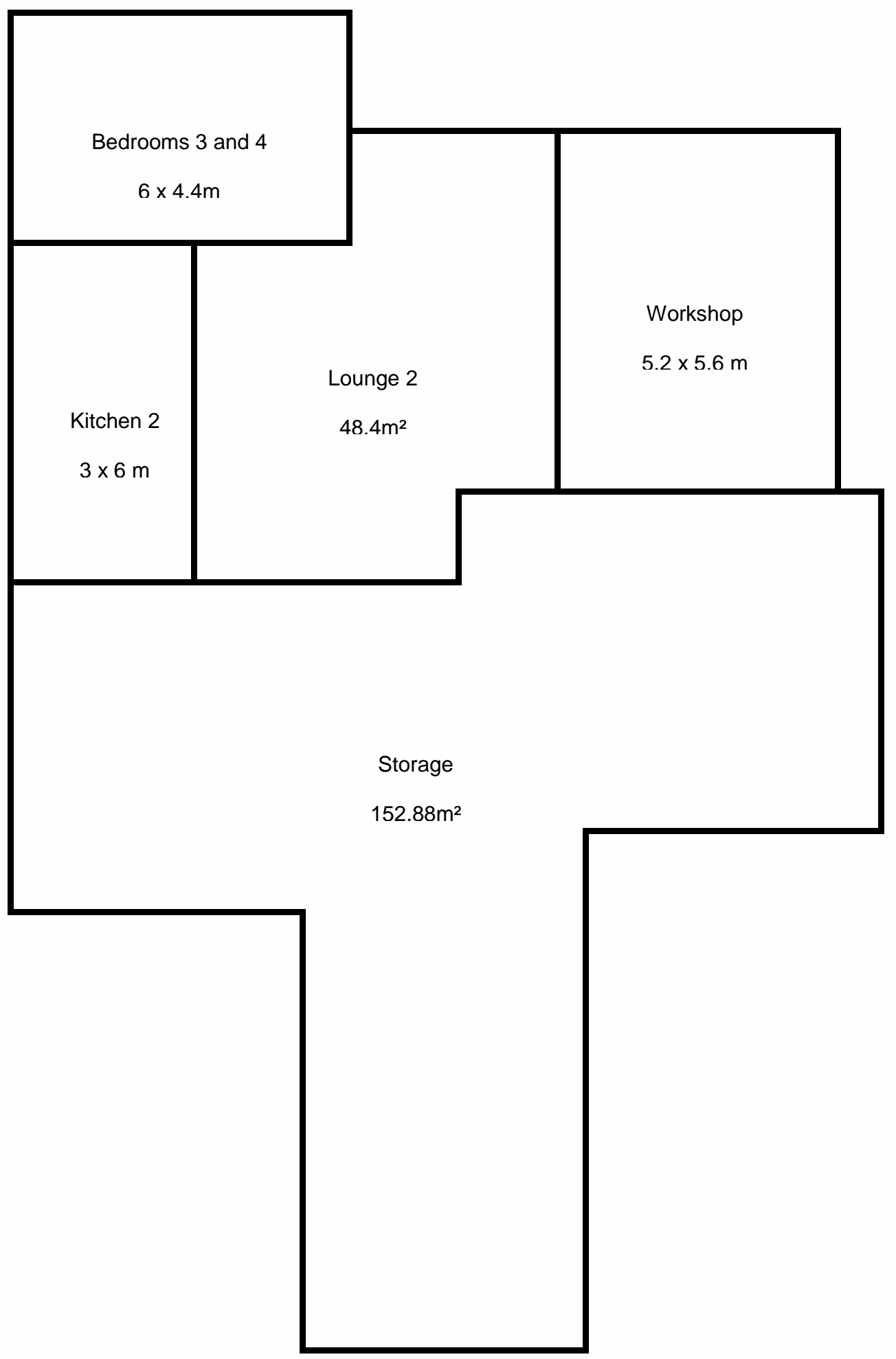


House Three $-87 \mathrm{~m}^{2}$

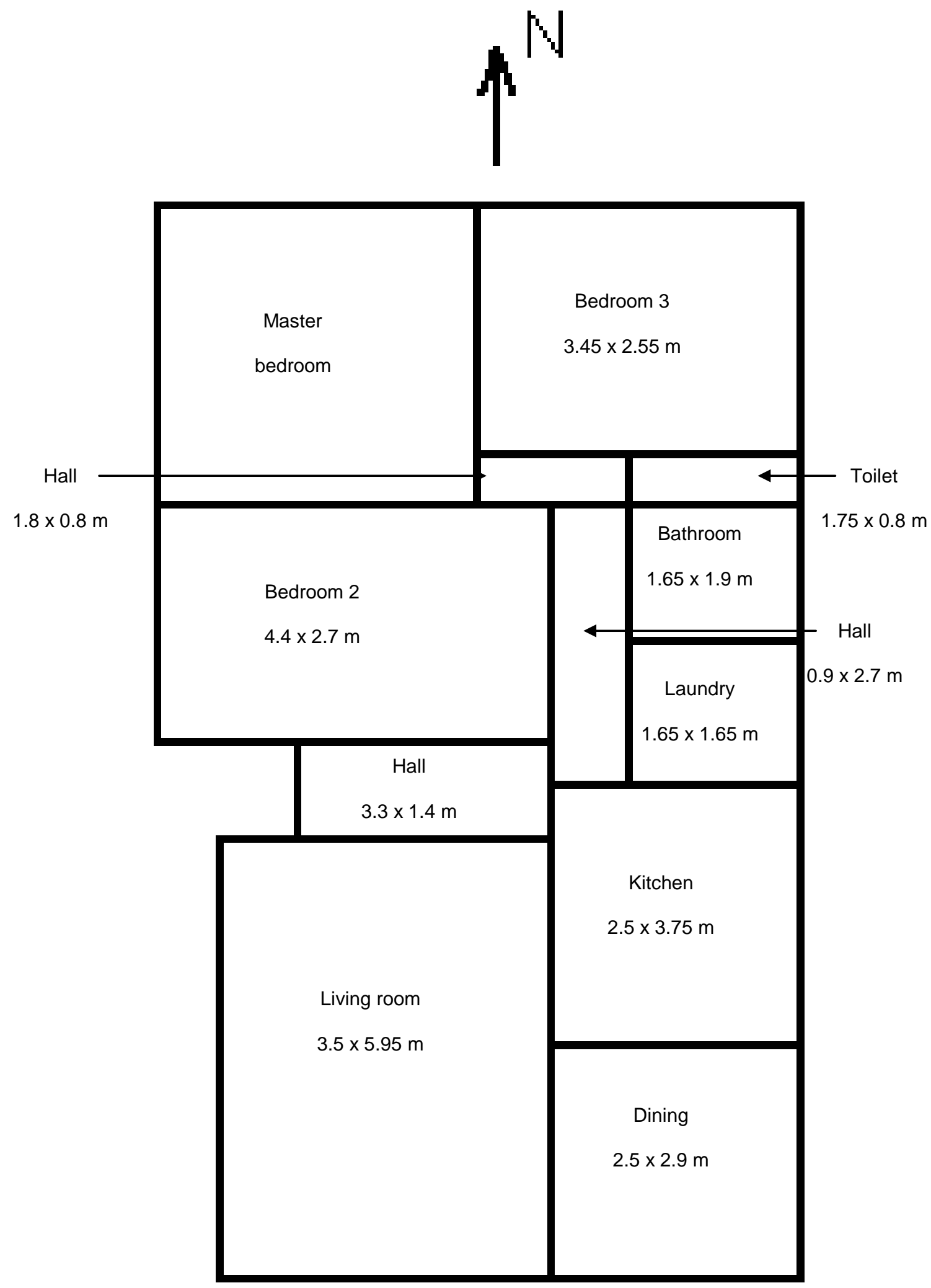


House Four - 195 m $^{2}$

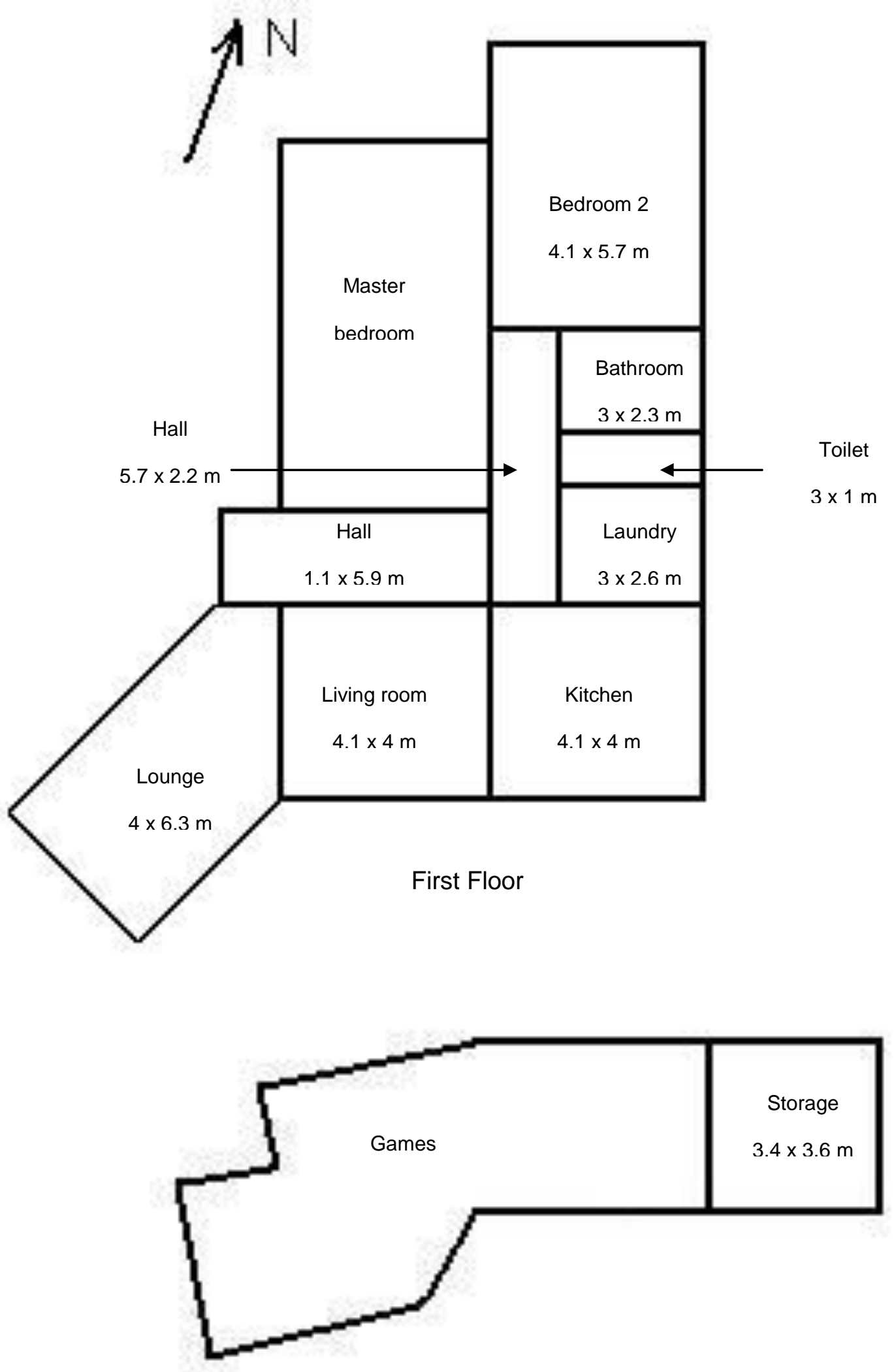


House Five $-245 \mathrm{~m}^{2}$

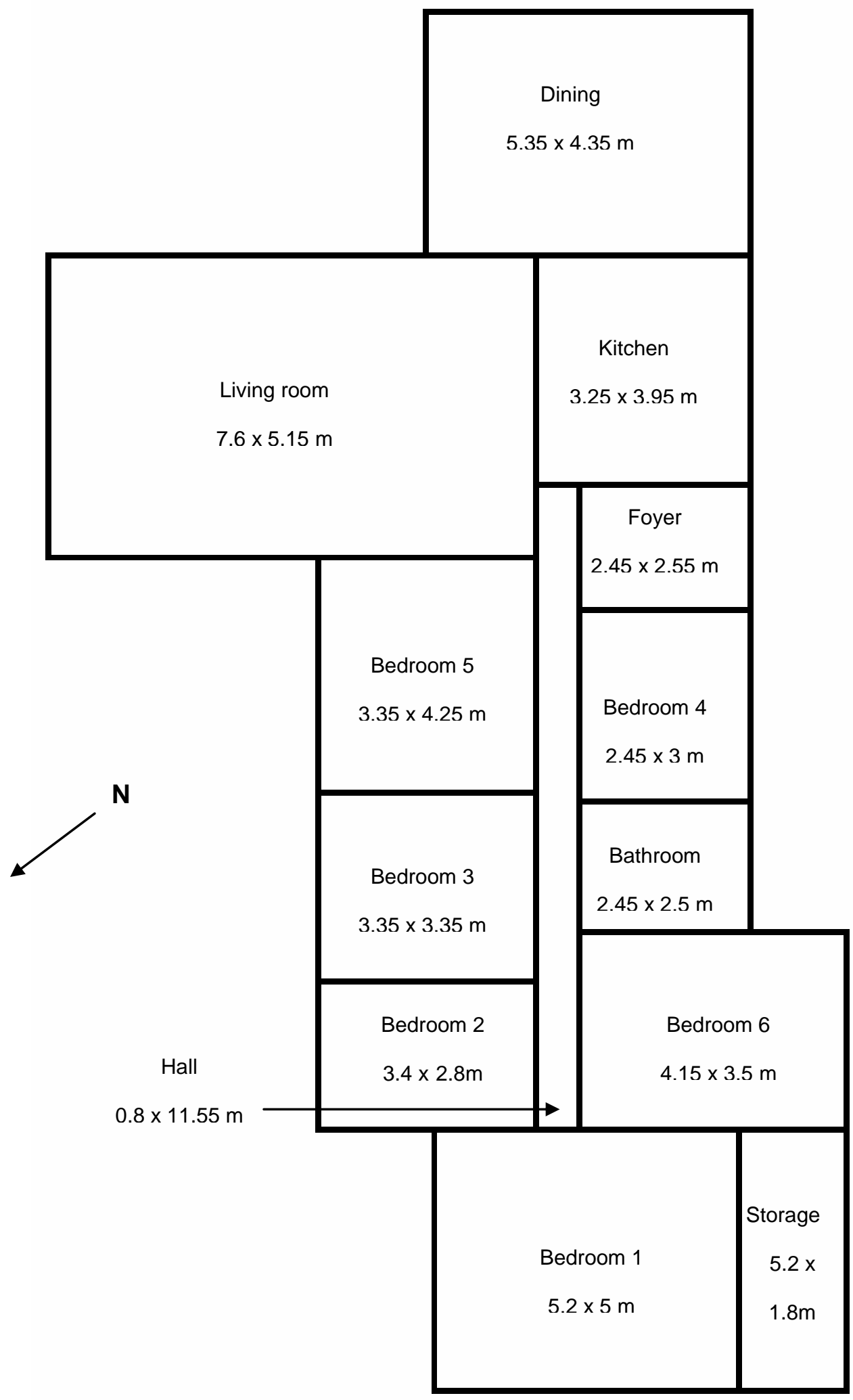




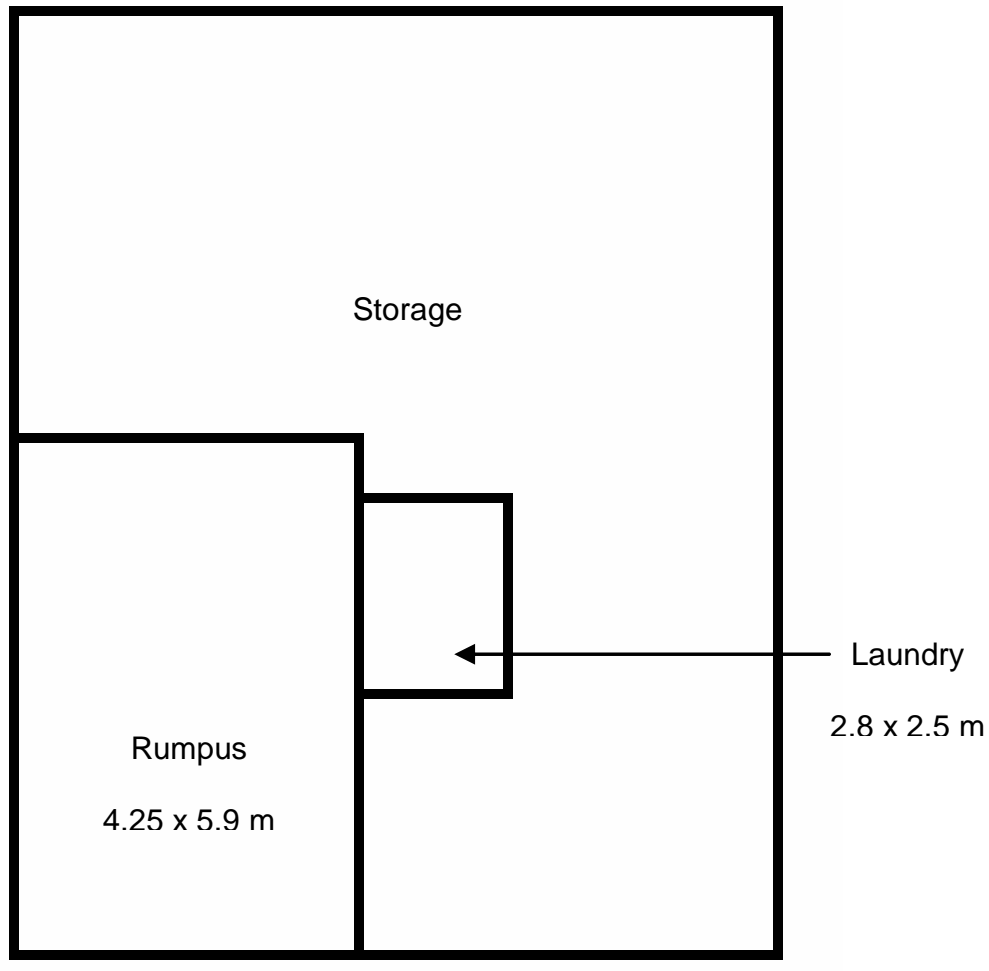

Ground Floor 


\section{Appendix C: Weather data}

The following tables in this appendix give a summary of the weather data used for modelling.

\begin{tabular}{|l|ccc|}
\hline \multirow{2}{*}{ Month } & \multicolumn{3}{|c|}{ Wind speed } \\
\cline { 2 - 4 } & Mean & Minimum & Maximum \\
& $\mathbf{m} / \mathbf{s}$ & $\mathbf{m} / \mathbf{s}$ & $\mathbf{~ m} / \mathbf{s}$ \\
\hline January & 3.1 & 0 & 8 \\
Mebruary & 2.8 & 0 & 8 \\
April & 3.2 & 0.3 & 7.8 \\
May & 2.4 & 0.3 & 7 \\
June & 2.3 & 0.1 & 6.1 \\
July & 2.6 & 0.1 & 9.1 \\
August & 2.4 & 0.1 & 7.3 \\
September & 2.7 & 0.2 & 6.5 \\
October & 3.2 & 0.5 & 9.4 \\
November & 3 & 0.1 & 6.6 \\
December & 3.2 & 0.3 & 7.6 \\
\hline Annual & 2.8 & 0.5 & 7.4 \\
\hline
\end{tabular}

Table 29: Wind speed monthly summary from SUNREL for 2003 


\begin{tabular}{|l|c|c|c|c|c|}
\hline \multirow{2}{*}{ Month } & \multicolumn{5}{|c|}{ Solar radiation } \\
\cline { 2 - 6 } & Direct & Unshaded & Direct & Diffuse & Total \\
& normal & horizontal & horizontal & horizontal & horizontal \\
MJ/SM & MJ/SM & MJ/SM & MJ/SM & MJ/SM \\
\hline January & 31.5 & 65.7 & 23.7 & 41.9 & 65.7 \\
February & 26.7 & 47.6 & 18.7 & 28.9 & 47.6 \\
March & 23.7 & 43.5 & 15.0 & 28.5 & 43.5 \\
April & 18.7 & 36.5 & 9.8 & 26.7 & 36.5 \\
May & 14.8 & 26.1 & 6.2 & 20.0 & 26.1 \\
June & 11.5 & 18.3 & 4.2 & 14.1 & 18.3 \\
July & 13.3 & 21.3 & 5.1 & 16.1 & 21.3 \\
August & 16.2 & 27.3 & 8.0 & 19.4 & 27.3 \\
September & 21.1 & 34.0 & 12.7 & 21.3 & 34.0 \\
October & 26.9 & 46.1 & 18.8 & 27.3 & 46.1 \\
November & 31.3 & 51.7 & 23.2 & 28.5 & 51.7 \\
December & 32.6 & 55.6 & 25.0 & 30.6 & 55.6 \\
\hline Total & 268.3 & 473.6 & 170.4 & 303.2 & 473.6 \\
\hline
\end{tabular}

Table 30: Solar radiation monthly summary data from SUNREL for 2003 


\section{Appendix D: Skyline}

As SUNREL is a northern hemisphere program the tool is concerned with sun in the south rather than north, the opposite to New Zealand. A test was therefore done to check the direction labelled 'south' in SUNREL was actually meaning 'north' given a southern hemisphere latitude has been entered for the location data. A test box was run with a window in each compass direction and with and without a skyline. Solar gains for the windows were examined in the results, to determine the effect of entering a negative number in the latitude on the direction of the skyline. This test confirmed entering a southern hemisphere latitude (or negative latitude) meant the skyline values centre around north rather than south. However the label in the skyline still says 'south' unless manually changed in the header file. 


\section{Appendix E: PMV and PPD}

The PMV and PPD as given in ISO 7730:2005 (International Standard Organization 2005) is designed for predicting the thermal sensation and degree of discomfort experienced in the houses.

The PMV predicts the mean value of a large group of persons to determine the thermal sensation on a seven-point thermal sensation scale (see Figure 24). The PMV index is based on the heat balance of the human body, and thermal balance occurs when the internal heat production in the body is equal to the loss of heat to the environment. The PMV index has been related statistically to thermal sensation votes collected from more than 1,300 people (International Standard Organization 2005).

The following equations (International Standard Organization 2005) were used for the calculation of PMV and PPD. Table 31 gives descriptions of parameters used and the assumptions where required.

Equation 1: Predicted Mean Vote (PMV)

$$
\begin{aligned}
& P M V=\left(0.303 e^{-0.036 M}+0.028\right)\left\{(M-W)-3.05 \times 10^{-3} \times\left[5733-6.99(M-W)-P_{a}\right]\right. \\
& -0.42[(M-W)-58.15]-1.7 \times 10^{-5} M\left(5867-P_{a}\right)-0.001 \times 4 M\left(34-t_{a}\right)-3.96 \times 10^{-8} \\
& \left.f_{c l} \times\left[\left(t_{c l}+273\right)^{4}-\left(\bar{t}_{r}+273\right)^{4}\right]-f_{c l} h_{c}\left(t_{c l}-t_{a}\right)\right\}
\end{aligned}
$$

Equation 2: Predicted Percentage of People Dissatisfied (PPD)

$$
P P D=100-95 \times \exp \left(-0.03353 \times P M V^{4}-0.2179 \times P M V^{2}\right)
$$


Where:

Equation 3: Ratio of clothing

$$
f_{c l}=\left\{\begin{array}{l}
1.00+1.290 \times I_{c l} \text { for } I_{c l} \leq 0.078 \\
1.05+0.645 \times I_{c l} \text { for } I_{c l}>0.078
\end{array}\right.
$$

Equation 4: Convective heat transfer coefficient

$$
h_{c}=\left\{\begin{array}{cc}
2.38\left(t_{c l}-t_{a}\right)^{0.25} & \text { for } 2.38\left(t_{c l}-t_{a}\right)>12.1 \sqrt{v_{a r}} \\
12.1 \sqrt{\mathrm{v}_{\mathrm{ar}}} & \text { for } 2.38\left(\mathrm{t}_{\mathrm{cl}}-\mathrm{t}_{\mathrm{a}}\right)^{0.25}<12.1 \sqrt{\mathrm{v}_{\mathrm{ar}}}
\end{array}\right.
$$

Equation 5: Surface temperature of clothing

$$
t_{c l}=35.7-0.028(M-W)-I_{c l}\left\{3.96 \times 10^{-8} f_{c l}\left[\left(t_{c l}+273\right)^{4}-\left(\bar{t}_{r}+273\right)^{4}\right]+f_{c l} h_{c}\left(t_{c l}-t_{a}\right)\right\}
$$

Where:

PMV is the Predicted Mean Vote

$\mathrm{M} \quad$ is the metabolic rate in $\mathrm{W} / \mathrm{m}^{2}$ of the body surface area

$\mathrm{W}$ is the external work in $\mathrm{W} / \mathrm{m}^{2}$ equal to 0 for most activities

$\mathrm{I}_{\mathrm{Cl}} \quad$ is the thermal resistance of clothing in $\mathrm{m}^{2} .{ }^{\circ} \mathrm{C} /$

$f_{c l} \quad$ is the ratio of man's surface area while clothed, to man's surface area while nude

$\mathrm{t}_{\mathrm{a}} \quad$ is the air temperature in ${ }^{\circ} \mathrm{C}$

$t_{r} \quad$ is the mean radiant temperature in ${ }^{\circ} \mathrm{C}$

$\mathrm{V}_{\mathrm{ar}}$ is the relative air velocity (relative to the human body) in $\mathrm{m} / \mathrm{s}$

$\mathrm{P}_{\mathrm{a}} \quad$ is the partial water vapour pressure in Pascals

$\mathrm{h}_{\mathrm{c}} \quad$ is the convective heat transfer coefficient in $\mathrm{W} /{ }^{\circ} \mathrm{C}$

$\mathrm{t}_{\mathrm{cl}} \quad$ is the surface temperature of clothing in ${ }^{\circ} \mathrm{C}$. 
Where estimated the same value is used both for the models and the measured houses.

\begin{tabular}{|c|c|c|}
\hline Symbol & Description & \\
\hline PMV & $\begin{array}{l}\text { Is the } \\
\text { Predicted } \\
\text { Mean Vote }\end{array}$ & Calculated in Equation 1 \\
\hline $\bar{M}$ & $\begin{array}{l}\text { Is the } \\
\text { metabolic } \\
\text { rate in } \mathrm{W} / \mathrm{m}^{2} \\
\text { of the body } \\
\text { surface } \\
\text { area }\end{array}$ & Estimated to be $70 \mathrm{~W} / \mathrm{m}^{2}$ (1.2 met) sedentary activity (office, dwelling, school, laborator) \\
\hline W & $\begin{array}{l}\text { Is the } \\
\text { external } \\
\text { work in } \\
\mathrm{W} / \mathrm{m}^{2} \text { equal } \\
\text { to } 0 \text { for } \\
\text { most } \\
\text { activities }\end{array}$ & \\
\hline $\mathrm{I}_{\mathrm{cl}}$ & $\begin{array}{l}\text { Is the } \\
\text { thermal } \\
\text { resistance } \\
\text { of clothing } \\
\text { in } \mathrm{m}^{2} .{ }^{\circ} \mathrm{C} \text { / } \\
\text { W }\end{array}$ & $\begin{array}{l}\text { Estimated to be } 0.080 \mathrm{~m}^{2} . \mathrm{K} / \mathrm{W}(0.5 \mathrm{clo}) \text { - underpants, shirt with short sleeves, light tro } \\
\text { light socks and shoes }\end{array}$ \\
\hline$f_{c l}$ & $\begin{array}{l}\text { Is the ratio } \\
\text { of man's }\end{array}$ & Calculated from Equation 3 \\
\hline
\end{tabular}




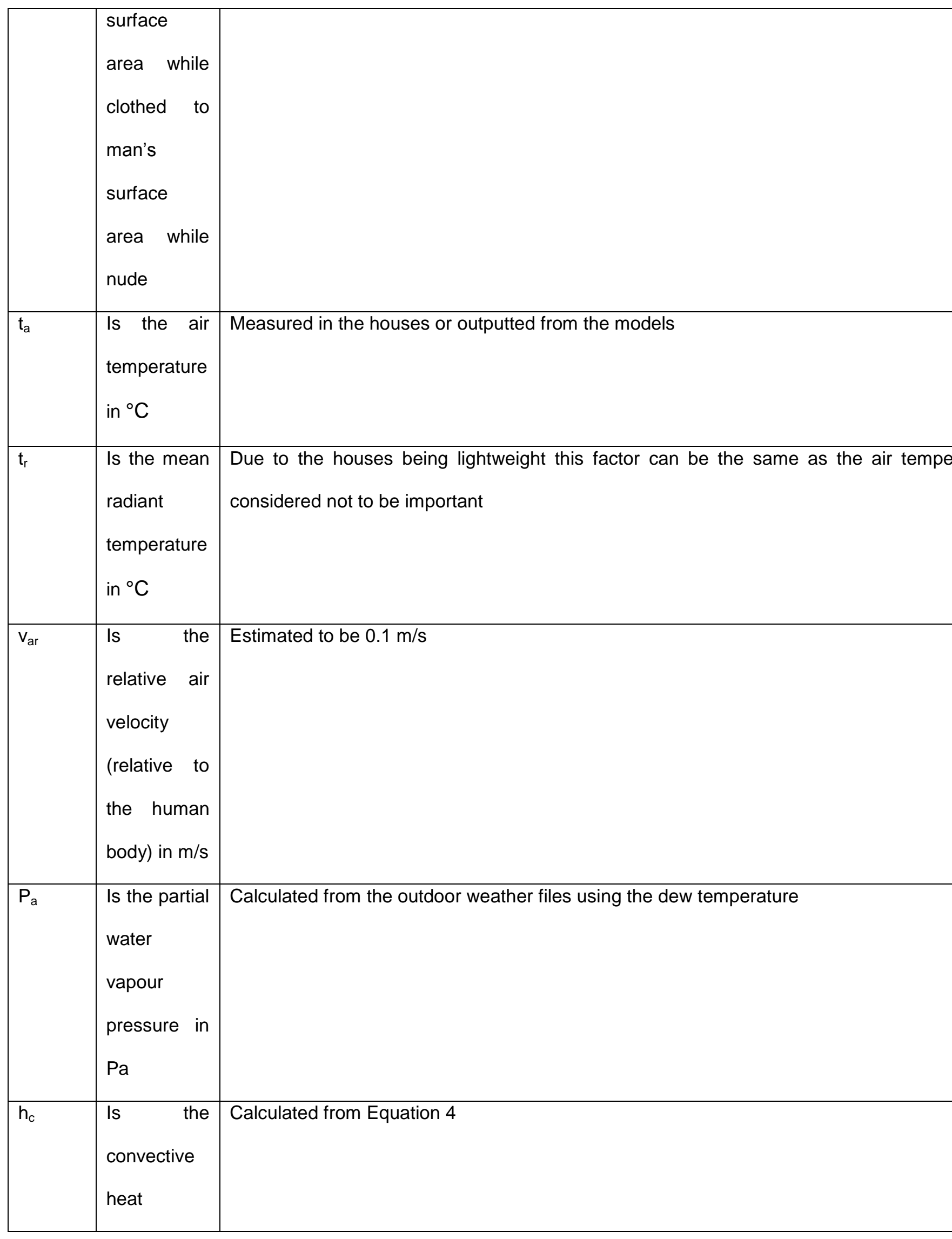




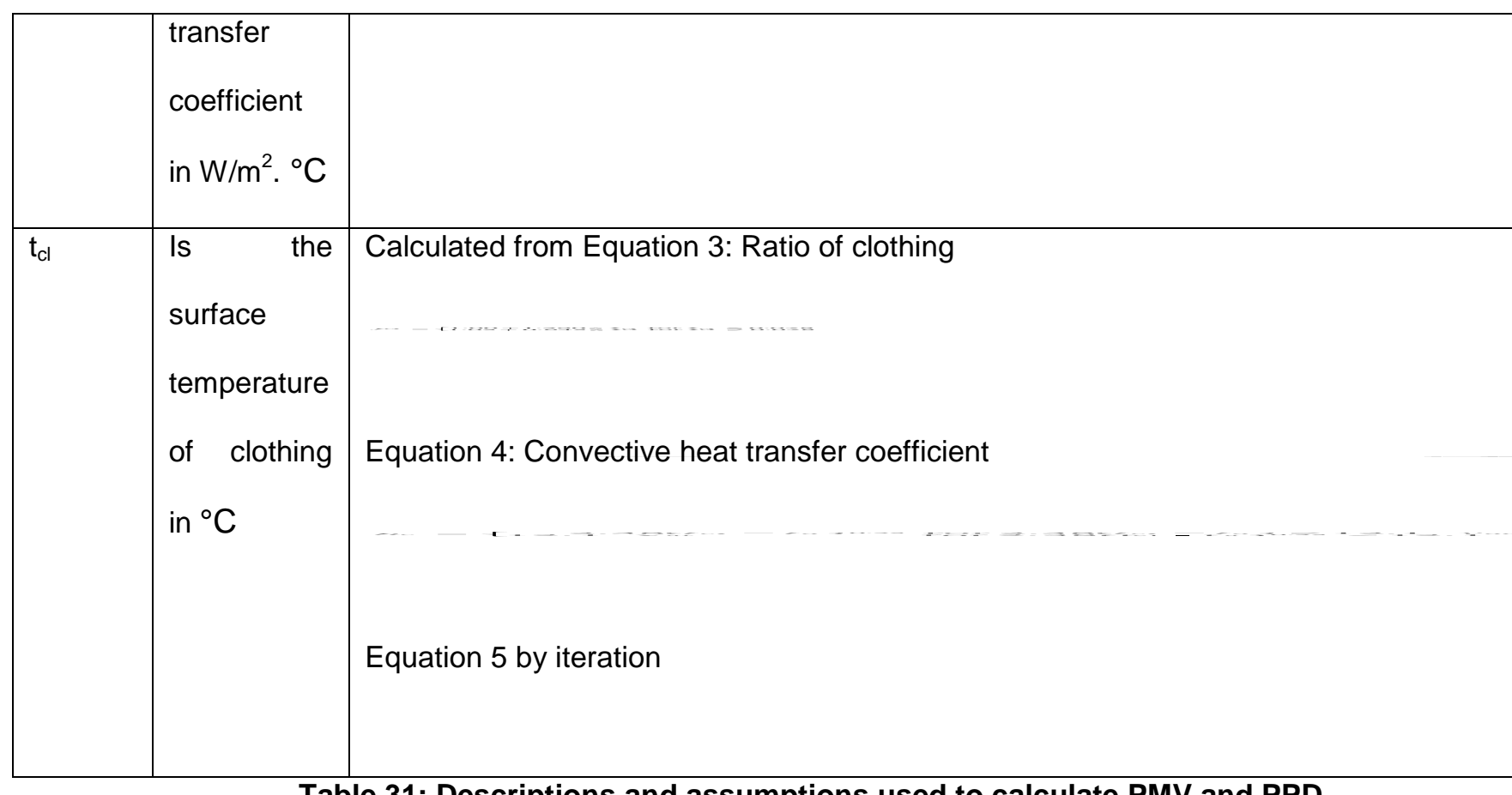

Table 31: Descriptions and assumptions used to calculate PMV and PPD

The PMV should only be used for values between -2 and +2 and when the six main parameters are within the following intervals:

M $\quad 46 \mathrm{~W} / \mathrm{m}^{2}$ to $232 \mathrm{~W} / \mathrm{m}^{2}$ (0.8 met to 4 met)

$\mathrm{I}_{\mathrm{cl}} \quad 0 \mathrm{~m}^{2} . \mathrm{K} / \mathrm{W}$ to $0.310 \mathrm{~m}^{2} . \mathrm{K} / \mathrm{W}$ (0 clo to 2 clo $)$

$t_{\mathrm{a}} \quad 10^{\circ} \mathrm{C}$ to $30^{\circ} \mathrm{C}$

$t_{r} \quad 10^{\circ} \mathrm{C}$ to $40^{\circ} \mathrm{C}$

$v_{\text {ar }} \quad 0 \mathrm{~m} / \mathrm{s}$ to $1 \mathrm{~m} / \mathrm{s}$

$\mathrm{P}_{\mathrm{a}} \quad 0 \mathrm{~Pa}$ to $2,700 \mathrm{~Pa}$

Equation 6: Saturation pressure over liquid water

$\ln \left(P_{w s}\right)=C_{8} / T+C_{9}+C_{10} T+C_{11} T^{2}+C_{12} T^{3}+C_{13} \ln T$

Where:

$\mathrm{C}_{8} \quad-5.8002206 \mathrm{E}+03$ 


$\begin{array}{ll}\mathrm{C}_{9} & 1.3914993 \mathrm{E}+00 \\ \mathrm{C}_{10} & -4.8640239 \mathrm{E}-02 \\ \mathrm{C}_{11} & -4.1764768 \mathrm{E}-05 \\ \mathrm{C}_{12} & -1.4452093 \mathrm{E}-08 \\ \mathrm{C}_{13} & 6.5459673 \mathrm{E}+00 \\ \mathrm{In} & \text { natural logarithm } \\ \text { OPws } & \text { saturation pressure, Pa } \\ \mathrm{T} & \text { absolute temperature }\end{array}$

Equation 7: Absolute temperature

$T=t+273.15$ 